
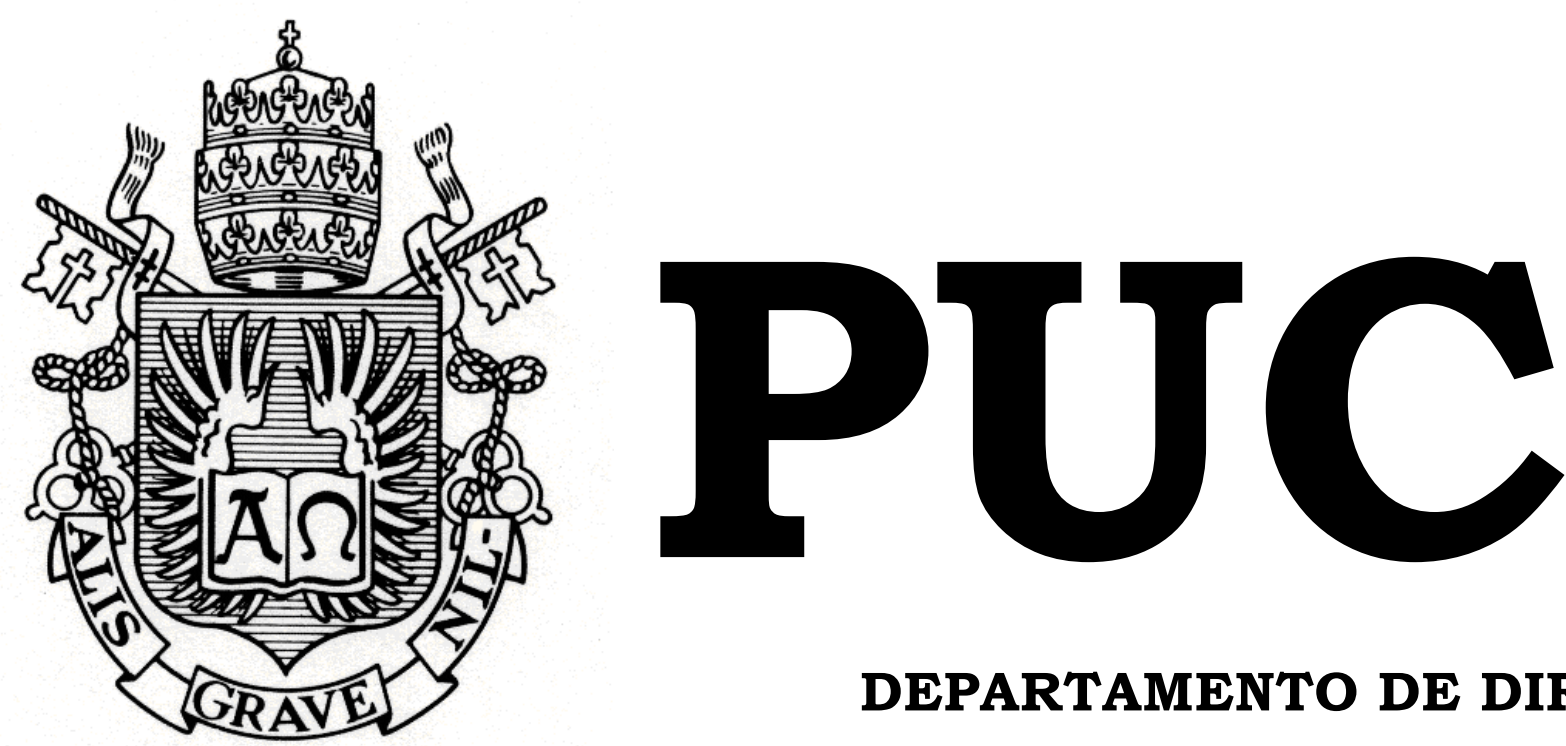

DEPARTAMENTO DE DIREITO

\title{
INTERESSES PATRIMONIAIS E POLÍTICOS DOS ACIONISTAS: CONSIDERAÇÕES SOBRE AS AÇÕES PREFERENCIAIS
}

por

GABRIEL CARVALHO DA COSTA

ORIENTADOR: Francisco Antunes Maciel Müssnich 2014.1

PONTIFÍCIA UNIVERSIDADE CATÓLICA DO RIO DE JANEIRO

RUA MARQUÊS DE SÃO VICENTE, 225 - CEP 22453-900

RIO DE JANEIRO - BRASIL 


\title{
INTERESSES PATRIMONIAIS E POLÍTICOS DOS ACIONISTAS: CONSIDERAÇÕES SOBRE AS AÇÕES PREFERENCIAIS
}

\author{
por \\ GABRIEL CARVALHO DA COSTA
}

\section{Monografia}

apresentada

ao

Departamento de Direito da Pontificia Universidade Católica do Rio de Janeiro (PUC-Rio) para a obtenção do Título de Bacharel em Direito.

Orientador: Francisco Antunes Maciel Müssnich. 


\section{Dedicatória}

Dedico o presente trabalho à minha mãe como forma de retribuir o amor e o apoio incondicionais. 


\section{Agradecimentos}

À minha família, por todo o carinho e apoio.

Aos meus amigos de infância e colégio, por fazerem essa época maravilhosa valer a pena, em especial, a Gabriel Baroni, pelos quase 20 anos de amizade.

Aos meus amigos da Puc-Rio, pelos incríveis 5 anos e por todo futuro que nos espera, em especial, a Pedro Brigagão, André Tosta, André Jahara e Marília Lopes.

A Norma Parente, pela dedicação, paciência, ensinamentos e discussões em nossos trabalhos de pesquisa acadêmica que contribuíram para a minha formação jurídica e a elaboração do presente trabalho.

Ao meu primeiro escritório, o BM\&A pela oportunidade e experiência, em especial a Amir Bocayuva, Rafaela Reina e Karina Lerner, pela amizade e aprendizado profissional.

Ao Stocche Forbes, pelo voto de confiança, em especial a Manuel Hermeto, Júlia Castello Branco, Pietro Bianchi e Maurício Veiga, por contribuírem diariamente para o meu amadurecimento profissional.

Ao meu orientador, professor, ex-colega de escritório e amigo, Chico Müssnich, pela disponibilidade, inspiração, ensinamentos e conselhos imprescindíveis para a minha formação jurídica e profissional. 


\section{Resumo}

O escopo do presente trabalho consiste em defender as ações preferenciais como uma importante alternativa para a captação de recursos por companhias abertas, frente a ameaça de esquecimento ou até mesmo da extinção das ações preferenciais decorrente da criação do Novo Mercado e da concepção de que o princípio "uma ação um voto" é o único meio de garantir o alinhamento entre emissores, administradores, investidores e o mercado em geral.

Nesse sentido, faz-se necessário resgatar a função econômica de tal instituto e refletir sobre os interesses dos agentes que compõe o mercado de capitais, de modo a demonstrar que o princípio "uma ação um voto" não se coaduna com a complexidade e sofisticação dos interesses dos integrantes do mercado de capitais brasileiro.

\section{Palavras-Chave:}

Ações Preferenciais; Direito de Voto; Golden Share; Superpreferenciais; Voto Plural; Novo Mercado. 


\section{Sumário}

1. Introdução

2. Considerações Gerais sobre as Ações Preferenciais.............................. 7

2.1. Do Conceito e Evolução Histórica.......................................................

2.2. Das Funções das Ações Preferenciais............................................... 16

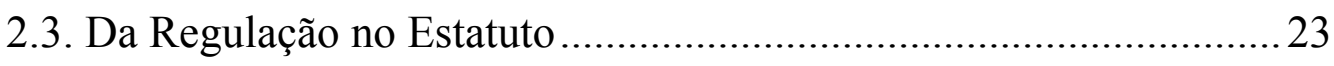

3. Vantagens e Preferências Atribuíveis às Ações Preferenciais sem

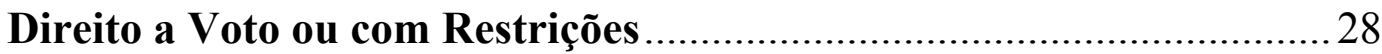

3.1. Das Preferências Relativas à Distribuição de Dividendos ................ 28

3.2. Outras Preferências ou Vantagens Patrimoniais ................................ 37

3.3. Das Preferências Políticas ou Administrativas .................................. 40

3.4. Das Restrições a Direitos ................................................................. 43

3.5. Das Ações Preferenciais sem Direito a Voto ou com Restrições Negociadas no Mercado de Valores Mobiliários ...................................... 45

4. Considerações Específicas sobre as Ações Preferenciais sem Direito a

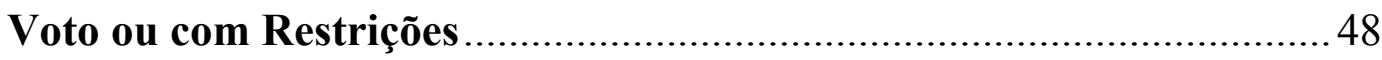

4.1. Do Direito de Voto e sua Função Econômica...................................... 48

4.2. Da Evolução Histórica da Discussão sobre o Princípio Uma Ação

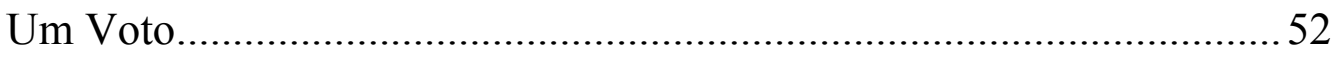

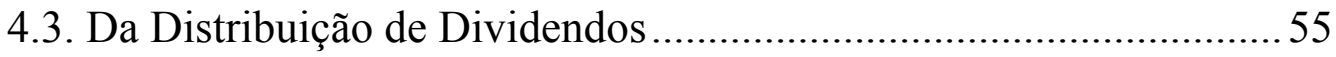

4.4. Da Aquisição do Direito de Voto........................................................ 63

5. Vantagens Superiores, Desproporção, Novo Mercado e Governança

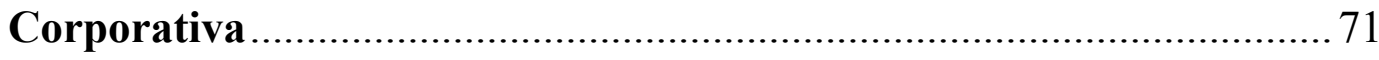

5.1. Das Vantagens Políticas Superiores - Golden Shares ....................... 71

5.2. Das Vantagens Econômicas Superiores - Superpreferenciais.......... 82

5.3. Do Voto Plural e Desproporção ......................................................... 91

5.4. Novo Mercado e Governança Corporativa ....................................... 96

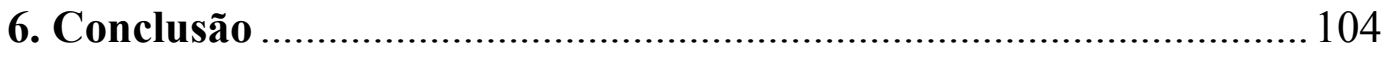

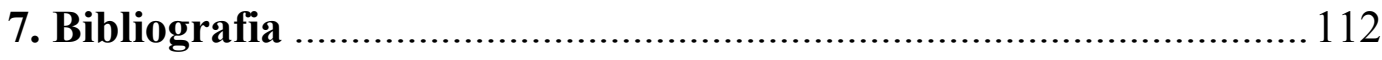




\section{Introdução}

O desenvolvimento mais significativo do mercado de capitais brasileiro iniciou-se na década de 1990, em razão da aceleração do movimento de abertura da economia brasileira, com o ingresso expressivo de recursos de investidores estrangeiros e o acesso, mesmo que inexpressivo, a mercados internacionais por parte de companhias brasileiras.

Entretanto, ao final dos anos 90, o mercado de capitais brasileiro, por diversas razões, dentre as quais a conjuntura econômica nacional e mundial, ainda não havia se desenvolvido plenamente, tendo sido afetado pelas crises econômicas que ocorreram em tal período (Crise da Rússia, Crise dos Tigres Asiáticos e, mais tarde, Crise das dot com) e a consequente escassez de recursos.

Neste contexto, em resposta às dificuldades enfrentadas pelo mercado de capitais brasileiro, surgiram diversas discussões sobre a necessidade de alterações da Lei $\mathrm{n}^{0}$ 6.404/76, bem como acerca da implantação de práticas de governança corporativa, incluindo a idealização do Novo Mercado. O fundamento principal das ideias que nortearam a criação do Novo Mercado residem no entendimento de que a fragilidade do mercado de capitais brasileiro teria sido causada, inclusive, pela ausência de proteção aos acionistas minoritários.

Basicamente, o Novo Mercado consiste em um segmento especial de listagem da BM\&FBOVESPA S.A. - Bolsa de Valores, Mercadorias e Futuros ("BM\&FBovespa"), estabelecida por meio de disposições constantes em um regulamento específico. 
A este mecanismo de autorregulação podem aderir as companhias que não tenham emitidos ações preferenciais e que estejam dispostas a assumirem obrigações adicionais às previstas em lei.

Desde 2004 até a presente data, cerca de aproximadamente $75 \%$ das ofertas iniciais de ações - initial public offering ("IPO's") foram realizadas por companhias listadas no segmento do Novo Mercado, demonstrando que a sua criação foi bem recebida pelo mercado em geral.

Em que pese a consistência do Novo Mercado, o fato de não serem admitidas companhias que emitam ações preferenciais não pode ser tomado como indicativo de que tais títulos não se coadunam com boas práticas de governança corporativa e com companhias comprometidas com a geração de valor as seus acionistas.

A difusão cada vez mais generalizada deste entendimento pode acabar por enterrar de vez o uso de ações preferenciais não votantes, comprometendo o desenvolvimento do mercado de capitais brasileiro, na medida em que (i) reduz as alternativas de captação de recursos; (ii) desconsidera interesses dos investidores que não desejam participar ativamente da gestão das companhias, apenas usando suas ações para especular, montar posições ou receber dividendos; e (iii) inviabiliza captação de recursos por parte de companhias que necessitam de uma estrutura de capital que não pode ser composta somente por ações ordinárias.

Diante da ameaça de esquecimento ou até mesmo da extinção das ações preferenciais, faz-se necessário resgatar a função econômica de tal instituto, bem como refletir sobre os interesses dos investidores e emissores que compõe o mercado, por meio de uma análise apta a contribuir para o debate em prol das ações preferenciais. 
Assim sendo, inicialmente o presente trabalho irá realizar breves considerações sobre a evolução do tratamento conferido às ações preferenciais no ordenamento jurídico brasileiro. Em seguida, serão analisadas as vantagens ou preferências mínimas que devem ser conferidas às ações preferenciais não votantes ou com restrição de voto. Por conseguinte, serão apresentadas breves considerações sobre determinadas questões controversas que ainda ensejam debates doutrinários. Por fim, o presente trabalho irá analisar outros instrumentos que acarretam desproporção de direitos políticos e contribuição econômica.

Isto posto, tem-se que o objetivo do presente trabalho consistirá em expor a finalidade, características e novas concepções para o uso das ações preferenciais, de modo a defendê-las como uma importante alternativa de captação de recursos, bem como demonstrar que o princípio uma ação um voto não se coaduna com a complexidade e sofisticação dos interesses dos integrantes do mercado de capitais brasileiro. 


\section{Considerações Gerais sobre as Ações Preferenciais}

\subsection{Do Conceito e Evolução Histórica}

A ação preferencial consiste no título que confere ao seu titular, determinadas vantagens ou preferências patrimoniais e/ou políticas, previstas no estatuto social, de acordo com os requisitos e limitações previstos na lei. Como destaca Carvalhosa "as ações preferenciais outorgam a seus titulares o status de acionistas, da mesma forma que as ações ordinárias, com todas os direitos essenciais que lhe são inerentes "l.

Desse modo, o acionista preferencial terá todos os direitos essenciais assegurados, nos termos do artigo 109 da Lei ${ }^{0}$ 6.404/76, porém, outros direitos que não os essenciais poderão ser-lhe negados, e em troca, serão concedidas preferências ou vantagens patrimoniais e/ou políticas, em relação às ações ordinárias. Nesse sentido, Ferreira ressalta que "as ações serão preferenciais relativamente às ações ordinárias. Preferência é o ato de preferir; e preferir é antepor, dar a primazia, o primeiro lugar; estimular mais, avantajar uma coisa de outra" ${ }^{2}$.

A ação preferencial brasileira advém do direito europeu, sendo essencialmente distinta da ação preferencial concebida no ordenamento jurídico norte-americano, a qual consiste em "um título de quase-divida, que assegura apenas direito a dividendos fixos (...) e não participa dos lucros que excederem desse dividendo, o que justifica sua classificação de silly investment ${ }^{\prime \prime 3}$.

\footnotetext{
${ }^{1}$ CARVALHOSA, Modesto. Ações preferenciais desprovidas de preferências. Revista dos Tribunais, 1994, vol. 707, pág. 41.

${ }^{2}$ FERREIRA, Waldemar. Tratado de Direito Comercial. São Paulo: Saraiva, 1961, vol. 4, pág. 239.

${ }^{3}$ LAMY, Alfredo; PEDREIRA, José Luiz Bulhões. Direito das Companhias. Alfredo Lamy e José Luiz Bulhões Pedreira (Coord.). Rio de Janeiro: Forense, 2009, vol.1, pág. 242.
} 
Atualmente, a realidade brasileira é bem diferente da norteamericana, pois a legislação pátria confere diversas possibilidades de preferências ou vantagens patrimoniais e/ou políticas aos acionistas preferenciais. Neste sentido, Carvalhosa ressalta que "(...) não é procedente a posição doutrinária no sentido de que as ações preferenciais são títulos de renda não tendo seus titulares ingerência na empresa. Os acionistas preferenciais não participam apenas financeiramente da sociedade, mas de toda vida social"4.

"Até o ano de 1932, quando surgiu o Decreto n ${ }^{\circ} 21.536 / 32$, o direito positivo brasileiro não reconhecia as ações preferenciais, regulando apenas as ações ordinárias ou comuns" ${ }^{5}$. No silêncio da lei, muito se discutia sobre a licitude da emissão de ações privilegiadas ou preferenciais, sempre conceituadas como aquelas que conferem, aos seus titulares, preferência nos lucros ou prioridade no reembolso, desconhecidas das ações ordinárias.

Durante a vigência do Decreto $n^{\circ}$ 434/81, a Companhia dos Fazendeiros de São Paulo consultou a Visconde de Ouro Preto e a Rui Barbosa, a respeito da possibilidade de emissão das "ações de prioridade". Ambos os consultados proferiram pareceres favoráveis à criação de tais ações e, desse modo, em 1916, inauguraram o sistema das ações privilegiadas. A conclusão de ambos os pareceres fundamenta-se no princípio da legalidade, de modo que, na ausência de qualquer proibição, a emissão de tais ações seriam lícitas ${ }^{6}$.

"Tais pronunciamentos deram ensejo a diversos debates doutrinários, com destaque para o aumento de capital da Caixa de Liquidação de São Paulo, em 1926, o qual deveria ser totalmente subscrito pelos seus credores.

\footnotetext{
${ }^{4}$ CARVALHOSA, Modesto. Op. Cit., pág. 41.

${ }^{5}$ VALVERDE, Trajano de Miranda. Sociedades por Ações. Rio de Janeiro: Forense, 1959, págs. 85 e 86.

${ }^{6}$ VALVERDE, Trajano de Miranda. Op. Cit., págs. 90 e 91.
} 
Desta vez, foram consultados J. X. Carvalho de Mendonça, Francisco Morato, Luiz Barbosa da Gama Cerqueira, Spencer Vampré e Waldemar Ferreira, prevalecendo o entendimento favorável à emissão de ações preferenciais",7.

Mesmo já tendo sido adotada por diversas companhias, não havia nenhuma previsão legal sobre a emissão de ações preferenciais, apenas o primeiro projeto de lei, elaborado em 1903. Conforme destacam seus autores:

"No Brasil, evidentemente, será proveitoso o uso de tais títulos, cuja vulgarização cumpre ao legislador promover. São óbvios os motivos, bastando lembrar que seria novo meio de atrair capitais estrangeiros, além de ser poderoso dique à ruína e às liquidações forçadas de muitas das nossas melhores sociedades anônimas" ${ }^{\prime \prime}$.

Em 15 de junho de 1932, a Associação Comercial do Rio de Janeiro e a Associação Bancária requereram, ao Governo Provisório, a elaboração e promulgação de um tratamento legal para as ações preferenciais. Nesse sentido, o Ministro Francisco Campos elaborou o projeto que mais tarde foi convertido no Decreto $\mathrm{n}^{\mathrm{o}} 21.526 / 32$, com base no projeto anterior de autoria de Clodomir Cardoso.

Desse modo, com a promulgação do Decreto no $21.526 / 32$, "admitiuse que as sociedades anônimas emitissem ações preferenciais de uma ou mais classes, atribuindo, à título de preferência, prioridade na distribuição de dividendos ou no reembolso de capital ou, ainda, a acumulação de ambas as vantagens"9.

\footnotetext{
${ }^{7}$ LEME, Ernesto. Das Acções Preferenciais nas Sociedades Anonymas. São Paulo: Saraiva, 1933, pág. 23.

${ }^{8}$ Autores do Primeiro Projeto de Lei sobre Ações Preferenciais, 1903. In. Direito das Companhias. Alfredo Lamy e José Luiz Bulhões Pedreira (Coord.). Rio de Janeiro: Forense, 2009, v.1, pág. 243. ${ }^{9}$ LEÃES, Luiz Gastão Paes de Barros. Ações Preferenciais Exclusivamente com Vantagens Políticas. Pareceres. São Paulo: Singular, 2004, vol. II, pág. 841.
} 
Convém destacar a justificativa elaborada pelo Ministro Francisco Campos, ao encaminhar o referido projeto, o qual foi posteriormente convertido no Decreto $\mathrm{n}^{\mathrm{o}} 21.526 / 32$ :

\begin{abstract}
"Se é dado real que a maioria das ações prima pelo absenteísmo às deliberações sociais, visando não à participação ativa na direção mas apenas ao rendimento do capital e às vantagens da especulação, por que não adotar o dado de realidade, revestindo-o de forma legal?

É o que faz o projeto, estabelecendo duas classes de acionistas que visam à participação ativa na direção da sociedade, com direito a voto, e acionistas que procuram ações sem serem levados pela affectio societais, mas apenas com intuito de especulação ou encontrar colocação segura ao capital.

A grande vantagem, porém, de ordem econômica e financeira, do sistema do projeto, é de criar, de acordo com os dados da realidade econômica, um tipo de ações que corresponde exatamente ao que procura a maior parte dos acionistas de sociedades anônimas, um tipo, em suma, que solicita apenas e com maior sedução do que o ordinário, o intuito de lucro e o desejo da especulação, móvel que, hoje em dia, influencia de modo preponderante o espírito da grande massa de detentores de capital mobiliário" ${ }^{10}$.
\end{abstract}

Tendo em vista que as primeiras ações preferenciais do ordenamento jurídico brasileiro foram emitidas sem que houvesse previsão legal nesse sentido, o artigo 14 do Decreto $\mathrm{n}^{\mathrm{o}}$ 21.526/32 dispunha que "as acções preferenciaes, emitidas antes do presente decreto, deverão conformar-se aos seus dispositivos, sem que estes, porém, a invalidem, nem as deliberações e os atos praticados na conformidade das leis que a regulavam".

Posteriormente, foi promulgado o Decreto-lei $\mathrm{n}^{\mathrm{o}} 2.627 / 40$, o qual transcreveu as regras dos dispositivos do Decreto $n^{0} 21.526 / 32$, apenas acrescentando o limite de emissão de $50 \%$ do capital total. Como destaca Valverde, "tendo em vista que não havia limite de emissão no âmbito do Decreto $n^{\circ} 21.526 / 32$, algumas sociedades chegaram a emitir mais de $90 \%$

\footnotetext{
${ }^{10}$ Exposição de Motivos encaminhada pelo Ministro Francisco Campos referente ao anteprojeto do Decreto $\mathrm{n}^{\circ}$ 21.526/32. Direito das Companhias. Alfredo Lamy e José Luiz Bulhões Pedreira (Coord.). Rio de Janeiro: Forense, 2009, v.1, pág. 243.
} 
de seu capital em ações preferenciais sem direito de voto, concentrando o poder político nas mãos de poucos acionistas ${ }^{11 " .}$

Além de serem incorporadas ao ordenamento jurídico brasileiro com o objetivo precípuo de serem títulos para o investidor, "tendo em vista o carácter genérico das preferências ou vantagens atribuídas, quais sejam o dividendo prioritário, a prioridade no reembolso em caso de liquidação ou a combinação de ambas, verifica-se que as ações preferenciais sempre tiveram as funções de instrumento de organização de companhias fechadas, bem como de composição de credores de companhias endividadas"12.

Em relação a esta última função, Lamy e Bulhões destacam que:

"(...) a empresa em dificuldade financeira normalmente necessita de capital próprio adicional, e os subscritores de novas ações não aceitam concorrer com os antigos acionistas e credores tanto na distribuição de dividendos quanto na repartição do acervo líquido, em caso de liquidação. Para compor esses interesses, em regra os credores antigos concordam e converter seus créditos em capital social e as novas ações subscritas em dinheiro têm prioridade, em relação aos antigos acionistas, e os credores cujos créditos foram capitalizados, na distribuição de dividendos e, se gozarem de prioridade no rateio do acervo líquido, terão - em caso de falência da companhia - o direito e receber o capital aplicado antes dos credores antigos, cujas ações ficam subordinadas às da nova emissão" ${ }^{\prime 13}$.

Com o passar dos anos, houve uma grande mudança da economia brasileira, marcada principalmente pelo desenvolvimento do setor industrial, sendo necessária uma mudança da perspectiva e do tratamento conferido ao mercado de capitais. Nas palavras de Retto:

"A partir de 1930, o País adentrou em nova fase de seu desenvolvimento econômico com a expansão do setor secundário. As companhias surgidas encontraram no Decreto $n^{\circ}$ 21.536/1932, importante instrumento de captação com a possibilidade de emissão de ações preferenciais sem voto, conferindo ao empresariado a possibilidade de crescimento sem pôr em perigo o controle da empresa. Instalada a Revolução de 1964, o primeiro governo militar empenhouse em desenvolver o mercado de capitais. (...) Paralelamente ao esforço de

\footnotetext{
${ }^{11}$ VALVERDE, Trajano Miranda. Op. Cit., pág. 90.

${ }^{12}$ LAMY, Alfredo; PEDREIRA, José Luiz Bulhões. Op. Cit., págs. 248 e 249.

${ }^{13}$ Ibid., pág. 249.
} 
criação de um mercado de capitais sofisticado e em consonância à realidade de então, marcada pela necessidade de se buscar instrumento capazes de direcionar a poupança interna, a predominância das sociedades anônimas familiares (fechadas) e a aversão ao "minoritarismo", foi promulgada a Lei 6.404/76, que trouxe importantes alterações no que concerne às ações preferenciais" ${ }^{14}$.

Desse modo, com a finalidade de desenvolver e sofisticar o mercado de capitais brasileiro, foi concebida e promulgada a Lei $n^{\circ}$ 6.404/76, "a qual reproduziu em seu artigo 17 o artigo 10 do Decreto-lei $n^{\circ}$ 2.627/40, acrescentando normas interpretativas das disposições estatutárias; assegurando a correção monetária do dividendo e do prêmio de reembolso fixados em moeda, bem como o direito de participar nos aumentos de capital decorrentes de correção monetária e da capitalização de reservas de lucros; destacando-se ainda, a previsão de atribuição de vantagens políticas, nos termos do seu artigo 18 e o aumento do limite de emissão de ações preferenciais sem direito a voto ou com voto restrito de $1 / 2$ para $2 / 3$ do número de ações que compõe o capital social"15.

No que tange a esta última alteração, convém destacar que durante a discussão do projeto da referida lei, houve acalorados debates sobre (i) o dispositivo que permitia a manutenção da emissão de preferenciais sem direito a voto; bem como (ii) a elevação do seu limite para a proporção de até $2 / 3$ das ações emitidas.

"A ação preferencial sem direito de voto ou com restrições tem como finalidade básica a capitação de recursos sem que haja modificação do controle da companhia emissora, pois sua emissão não interfere na composição do capital votante"16. Assim, tais títulos foram "concebidos de modo a ajustarem-se à demanda dos investidores que procuram segurança

\footnotetext{
${ }^{14}$ RETTO, Marcel Gomes Bragança. Evolução Legislativa das Ações Preferenciais no Brasil e os Institutos a Elas Relacionados. Revista de Direito Mercantil, Industrial, Econômico e Financeiro, 2004, vol. 133, págs. 128 e 129.

${ }^{15}$ LAMY, Alfredo; PEDREIRA, José Luiz Bulhões. Op. Cit., pág. 244.

${ }^{16}$ WALD, Arnoldo. Em Defesa das Ações Preferenciais. Revista de Direito Mercantil, Industrial, Econômico e Financeiro, $n^{\circ}$ 78, 1990, pág. 20.
} 
de rendimento e possuem interesse por trocar o direito de voto, que não exercem, por vantagens patrimoniais em relação ao recebimento de dividendos, permitindo ao acionista controlador captar recursos no mercado de valores mobiliários sem pôr em risco o seu controle"17.

Convém destacar que a Lei no 6.404/76 não definiu, expressamente, o conceito de controle, o qual deve ser concebido de acordo com o conceito de acionista controlador, previsto em seu artigo 116. Assim sendo, para fins do presente trabalho, poder de controle consiste na (i) titularidade de direitos de sócio que assegurem, de modo permanente, a preponderância nas deliberações sociais e o poder de eleger a maioria dos administradores; em conjunto com (ii) o uso efetivo deste poder para direção das atividades sociais e orientação do funcionamento dos órgãos de administração da companhia.

Nesse sentido, Lamy e Bulhões esclarecem que:

"Controle é a capacidade de causar, determinar ou alterar a ação dos órgão da companhia. É o poder político na sociedade, no sentido de poder supremo da sua estrutura interna, que compreende a capacidade de alocar e distribuir poder nessa estrutura. (...) Esse poder é de fato, e não de direito: cada ação confere apenas o direito (ou poder jurídico) de um voto, e o controle nasce do fato da formação do bloco de controle" ${ }^{\prime 18}$.

Contudo, na aplicação da redação original da Lei $\mathrm{n}^{\circ}$. 6.404/76, nem sempre foram conferidas às ações preferenciais a devida compensação pela restrição política que sofrem, tendo em vista que diversas companhias realizaram a emissão de ações preferenciais sem direito de voto ou com restrições, atribuindo em seus estatutos sociais somente vantagens vazias e inócuas para os acionistas preferenciais, deturpando a lógica da incorporação deste instituto no ordenamento jurídico brasileiro.

\footnotetext{
${ }^{17}$ LAMY, Alfredo; PEDREIRA, José Luiz Bulhões. Op. Cit., pág. 244.

${ }^{18}$ LAMY, Alfredo; PEDREIRA, José Luiz Bulhões. A Lei das S.A. Rio de Janeiro: Renovar, $3^{\text {a }}$ Edição, 1997, pág. 66.
} 
Desse modo, "difundiu-se a criação de ações preferenciais sem direito de voto nem dividendo prioritário, sendo atribuída, apenas, a prioridade no reembolso em caso de liquidação da companhia, a qual somente representa uma vantagem efetiva para a composição de credores da companhia, caso haja possibilidade de falência da companhia no curto prazo" $^{19}$. Nas palavras de Carvalhosa:

“(...) a lei não admite a privação do direito de voto à preferenciais sem que haja a correspondente compensação pecuniária. Pode-se, portanto, afirmar que as chamadas ações preferenciais, às quais é assegurado unicamente a prioridade no recebimento de dividendos não têm e nunca tiveram a natureza de ação preferencial; (...) o que caracteriza a ação preferencial são os direitos privilegiados que estatutariamente lhe são conferidos em relação às ordinárias" $"$.

Assim sendo, "a prática de emitir ações preferenciais não votantes sem atribuir a devida contrapartida em vantagens patrimoniais efetivas, em conjunto com a elevação para $2 / 3$ do limite de emissão de tais ações, realizada pela Lei $\mathrm{n}^{\mathrm{o}}$ 6.404/76, ocasionou a predominância de ações preferenciais sem voto e sem vantagens no mercado" ${ }^{21}$, consistindo, nas palavras de Akkerman e Fragoso "em excessos perpetrados por acionistas controladores que (...) cometeram abusos em prejuizo do interesse dos acionistas e do patrimônio da companhia" ${ }^{22}$.

Tais distorções e excessos fomentaram críticas à existência das ações preferenciais e motivaram debates visando o fortalecimento do mercado de capitais brasileiro, capitaneados, principalmente, por reformas com propostas em duas vertentes: (i) assegurar vantagens mínimas às ações

\footnotetext{
${ }^{19}$ LAMY, Alfredo; PEDREIRA, José Luiz Bulhões. Op. Cit., pág. 245.

${ }^{20}$ CARVALHOSA, Modesto. Op. Cit., pág. 45.

${ }^{21}$ LAMY, Alfredo; PEDREIRA, José Luiz Bulhões. Op. Cit., pág. 245.

${ }^{22}$ FRAGOSO, Daniela Neves Reali. AKKERMAN, Gustavo. Ações Preferenciais: Evolução ou Retrocesso?. In Temas de Direito Societário e Empresarial Contemporâneos. São Paulo: Malheiros, 2011, pág. 280.
} 
preferenciais; ou, em sentido contrário, (ii) excluir as ações preferenciais do ordenamento jurídico brasileiro.

Assim, tendo em vista que "os direito conferidos às ações preferenciais até a promulgação da Lei 9.457/1997 consistiam em "vantagens formais", muitas vezes de ordem cronológica" ${ }^{23}$, prevaleceram as propostas que defendiam o estabelecimento de preferências patrimoniais mínimas em relação às ações preferenciais sem direito de voto ou com restrições que seriam emitidas no âmbito de ofertas públicas, com a consequente negociação em bolsa ou no mercado de balcão. Lamy e Bulhões destacam que:

"Na discussão do projeto que se transformou na Lei $n^{\circ}$. 9.457/97, esse requisito [atribuição de prioridade do reembolso como vantagem patrimonial] teve grande resistência das companhias abertas e acabou por prevalecer nesta lei um novo inciso do artigo 17, atribuindo às preferências sem direito a dividendos fixo ou mínimo, cumulativos ou não - ou seja - cuja única prioridade era o reembolso de capital em caso de liquidação -, direito a dividendo, no mínimo, $10 \%$ maior do que o atribuído às ações ordinárias"

Em 2001, foi promulgada a Lei $\mathrm{n}^{\circ}$. 10.303/01, a qual "modificou novamente o artigo 17 da Lei $\mathrm{n}^{\circ}$. 6.404/76, estabelecendo em seus incisos os três tipos de vantagens já previstas em leis anteriores, bem como criando outras normas que obrigam a atribuição de, no mínimo, uma das três opções de vantagens previstas em seu $\S 1^{\circ}$, para que as ações preferenciais sejam admitidas à negociação no mercado de valores mobiliários"24, conforme a redação abaixo:

\footnotetext{
"Art. 17. As preferências ou vantagens das ações preferenciais podem consistir:

I - em prioridade na distribuição de dividendo, fixo ou mínimo;

II - em prioridade no reembolso do capital, com prêmio ou sem ele; ou

III - na acumulação das preferências e vantagens de que tratam os incisos I e II.

$\$ 1^{\circ}$ Independentemente do direito de receber ou não o valor de reembolso do capital com prêmio ou sem ele, as ações preferenciais sem direito de voto ou com restrição ao exercício deste direito, somente serão admitidas à negociação no
}

\footnotetext{
${ }^{23}$ RETTO, Marcel Gomes Bragança. Op. Cit., pág. 135.

${ }^{24}$ LAMY, Alfredo; PEDREIRA, José Luiz Bulhões. Op. Cit., pág. 246.
} 
mercado de valores mobiliários se a elas for atribuida pelo menos uma das seguintes preferências ou vantagens:

I - direito de participar do dividendo a ser distribuido, correspondente a, pelo menos, $25 \%$ (vinte e cinco por cento) do lucro líquido do exercício, calculado na forma do art. 202, de acordo com o seguinte critério:

a) prioridade no recebimento dos dividendos mencionados neste inciso correspondente a, no mínimo, $3 \%$ (três por cento) do valor do patrimônio líquido da ação;e

b) direito de participar dos lucros distribuídos em igualdade de condições com as ordinárias, depois de a estas assegurado dividendo igual ao mínimo prioritário estabelecido em conformidade com a alínea a; ou

II - direito ao recebimento de dividendo, por ação preferencial, pelo menos $10 \%$ (dez por cento) maior do que o atribuído a cada ação ordinária; ou

III - direito de serem incluídas na oferta pública de alienação de controle, nas condições previstas no art. 254-A, assegurado o dividendo pelo menos igual ao das ações ordinárias".

Além das modificações descritas acima, "a reforma introduzida pela Lei $n^{0} 10.303 / 01$ diminuiu o número permitido de emissão de ações preferenciais sem direito a voto ou com restrições, em uma oferta pública de ações de $2 / 3$ para $1 / 2$ do total de ações emitidas, reduzindo eventual disparidade entre capital investido e direito de voto" ${ }^{25}$, nos termos da seguinte nova redação conferida ao $\S 2^{\circ}$ do artigo 15 da Lei ${ }^{\circ}$ 6.404/76:

\footnotetext{
"Art. 15. As ações, conforme a natureza dos direitos ou vantagens que confiram a seus titulares, são ordinárias, preferenciais, ou de fruição.

(...)

$\S 2^{\circ} \mathrm{O}$ número de ações preferenciais sem direito a voto, ou sujeitas a restrição no exercício desse direito, não pode ultrapassar 50\% (cinquenta por cento) do total das ações emitidas".
}

\subsection{Das Funções das Ações Preferenciais}

"De acordo com os livros de Finanças e a prática norte-americana, as ações preferenciais (preferred stock) consistem em papeis que conferem ao seu titular o direito ao pagamento de um dividendo fixo, com prioridade sobre qualquer distribuição de resultado às ações ordinárias"26.

\footnotetext{
${ }^{25}$ GORGA, Érica. Direito Societário Atual. Rio de Janeiro: Elsevier, 2013, pág. 146.

${ }^{26}$ FRAGOSO, Daniela Neves Reali. AKKERMAN, Gustavo. Op. Cit., pág. 289.
} 
Conforme já exposto no item 2.1 acima, a realidade brasileira diferese da norte-americana, principalmente no tocante às vantagens ou preferências que podem ser atribuídas às ações preferenciais sem direito de voto ou com restrições, contudo, a sua função econômica é a mesma: "servir de instrumento para a companhia captar recursos de pessoas interessadas em exercer a função empresarial apenas no que tange à aplicação de capital, sem interferir diretamente na gestão da companhia"27.

"Assim, as ações preferenciais são classificadas como um instrumento híbrido entre instrumentos de dívida e de capital próprio, pois confere o direito a um pagamento fixo da companhia emissora ao acionista, ao passo que, o inadimplemento do emissor em relação ao pagamento do dividendo fixo, não acarretará a falência ou liquidação da companhia emissora" ${ }^{28}$.

No ordenamento jurídico brasileiro, as ações preferenciais estão sujeitas a maior flexibilidade, podendo ter características que as associem mais a um instrumento de dívida, mantendo sempre características que as diferem das ações ordinárias e, desse modo, "servem para as mais díspares situações, pois as diferentes combinações e restrições (com ou sem direito de voto; com ou sem prioridade no recebimento de dividendos, cumulativos ou não, fixos, mínimos ou com participação integral; com ou sem direito de prioridade de reembolso de capital; resgatáveis ou não; conversíveis ou não em ações ordinárias, ou em ações preferenciais de outra classe; com direito de eleger administradores em votação em separado; com direito de veto em relação à determinadas alterações estatutárias; entre outras combinações) permitem conciliar os interesses da companhia emissora, de seus acionistas,

\footnotetext{
${ }^{27}$ PEDREIRA, José Luiz Bulhões. Finanças e Demonstrações Financeiras da Companhia. Rio de Janeiro: Forense, 1989, pág. 403.

${ }^{28}$ FRAGOSO, Daniela Neves Reali. AKKERMAN, Gustavo. Op. Cit., pág. 290.
} 
de potenciais investidores, bem como do mercado de valores mobiliários em geral"29.

Desse modo, para entender a função econômica das ações preferenciais, bem como os interesses dos investidores que optam por subscrever tais títulos, mostra-se necessária uma breve análise sobre a atividade empresarial e as pessoas que a exercem. Nesse sentido, Lamy e Bulhões explicam que:

\begin{abstract}
"Para o sucesso da sociedade anônima, como principal mecanismo institucional da economia de livre iniciativa, contribuiu sua característica de modelo jurídico de organização em que as três subfunções empresariais são bem definidas, facilitando seu exercício por pessoas diferentes. O empresário-empregador é fundador ou acionista controlador, e em geral exerce um dos cargos da administração; mas esses cargos podem ser ocupados por administradores profissionais, que não participam da criação da empresa nem são aplicadores de capital de risco. A função de investidor, graças à divisão do capital social em ações, pode ser exercida, simultaneamente, pelo empresário-empreendedor e por milhares ou milhões de investidores do mercado. Dai a flexibilidade do modelo, que serve para organizar desde a pequena empresa até as macroempresas dos países mais industrializados, 30
\end{abstract}

Ou seja, há a figura do empresário-empreendedor, o qual teve a iniciativa de conceber e implementar o negócio, assumir os riscos e reunir os fatores de produção necessários para criar e desenvolver a companhia e, portanto, detêm o seu controle, sendo o único proprietário ou sócio de um pequeno número de pessoas.

De modo geral, as companhias têm a necessidade de financiar a expansão de seus negócios. Se as atividades da companhia forem bem conduzidas, pode ser que esta consiga arcar com os custos de sua expansão por meio dos lucros gerados. Contudo, caso os lucros não sejam suficientes para arcar com os investimentos relativos à sua expansão, a companhia terá que obter financiamento externo. Assim, o empresário-empreendedor tem a

\footnotetext{
${ }^{29}$ LAMY, Alfredo; PEDREIRA, José Luiz Bulhões. Op. Cit., pág. 246.

${ }^{30}$ Ibid., pág. 247.
} 
alternativa de realizar a captação de recursos por meio de dívidas ou emissão de ações.

Da perspectiva do empresário empreendedor, utilizar instrumentos de dívida ao invés de emitir ações significa preservar o controle da companhia e evitar a diluição da participação, pois os instrumentos de dívida, em geral, não conferem aos credores o direito de participarem no capital social da companhia. Entretanto, a desvantagem de utilizar instrumentos de dívida, ao invés de emitir ações, reside na elevação do risco de falência da companhia, tendo em vista que os instrumentos de dívida estabelecem datas de vencimento para o pagamento do principal acrescido de juros.

Assim, as companhias que têm dúvidas quanto a capacidade de geração de receita suficiente para o adimplemento das dívidas assumidas encontram na emissão de ações a solução para a captação de recursos. O empresário-empreendedor até pode emitir ações e manter o controle da companhia, porém, a cada emissão sua participação será diluída.

Os subscritores das ações emitidas são os empresários-investidores, pessoas que em geral não têm a expertise necessária nem o interesse em interferir diretamente na condução das atividades da companhia, ou seja, visam apenas aplicar capital em troca de retorno econômico futuro, seja através do recebimento de dividendos ou da valorização de suas ações.

Por conseguinte, os empresários-investidores desejam que o empresário-empreendedor e os administradores da companhia (i) conduzam as atividades com eficiência, de modo a manter a companhia lucrativa; e (ii) cumpram com as suas obrigações legais e estatutárias, de modo a respeitar os seus direitos; pois, do contrário, os empresários-investidores têm a alternativa de alienarem suas ações no mercado. 
Como destacam Lamy e Bulhões "a divisão nítida de subfunções empresariais, facilitada pelo modelo de companhia, explica a omissão do público investidor em comparecer às assembleis gerais para discutir e votar as decisões sobre o destino da companhia, a não ser quando sente que há perigo de perder seu investimento (o absenteísmo dos acionistas será abordado no item 5.4 do presente trabalho)" ${ }^{\prime 31}$.

Nesse sentido, tendo em vista que a "organização da companhia é composta por acionistas diferentes, em termos de conhecimento, recursos financeiros, relações de mercado, reputação, experiência administrativa e objetivos empresarias, é praticamente impossível conciliar todos os interesses envolvidos com apenas uma espécie e classe de ações (a não ser completando as disposições do estatuto social com a celebração de acordos de acionistas), sendo necessária e recomendável a combinação de ações ordinárias e preferenciais, às vezes de diversas classes",32.

As ações preferenciais podem oferecer uma posição intermediária em relação aos interesses conflitantes entre manutenção do controle e elevação do risco de falência da companhia. Como já tido anteriormente, ações preferenciais nem sempre possuem pleno exercício do direito de $\operatorname{voto}^{33}$. Geralmente, o direito de voto das ações preferenciais decorre do não pagamento do dividendo preferencial por parte da companhia (ver item 4.5 do presente trabalho).

Desse modo, as companhias podem obter capital próprio, o qual tem a vantagem de não ser restituído se a companhia falhar em gerar receita

\footnotetext{
${ }^{31}$ Ibid., pág. 248.

${ }^{32}$ Ibid., pág. 248.

${ }^{33}$ Como enuncia Carvalhosa, “(...) tanto as ações ordinárias quanto as preferenciais têm direito de voto. A supressão desse direito, no que respeita às ações preferenciais, é uma faculdade e não uma imposição legal e deverá sempre estar expressa no estatuto social (...)". CARVALHOSA, Modesto. Ações Preferenciais Desprovidas de Preferências. pág. 41.
} 
suficiente, ao contrário dos instrumentos de dívida, ao passo que, o controle da companhia será mantido nas mãos do empresário-empreendedor, o qual tem a expertise e o interesse para conduzir as atividades sociais, desde que os dividendos preferenciais sejam pagos. Corroborando este entendimento, Fragoso e Akkerman enunciam que:

\begin{abstract}
“(...) a divisão do capital entre ações ordinárias e ações preferenciais, com possibilidade de restrição ou suspensão do direito de voto, seria instrumento apto a conciliar diversos de tais interesses, permitindo a formação de um sólido bloco de controle e assegurando aos investidores um retorno econômico mais vantajoso, com isso atraindo capitais para a expansão da grande empresa nacional. Sendo o empreendedor a mola propulsora deste processo de crescimento, deveria a lei incentivar e facilitar a ação deste empreendedor para chegar a tal ponto, por meio da detenção do poder de controle, ${ }^{, 34}$.

$\mathrm{O}$ entendimento exposto acima reflete, inclusive, a lógica do anteprojeto da Lei $n^{\circ}$ 6.404/76, tendo em vista "conferir liberdade para a organização empresarial e ampliar as alternativas de capitalização, enquanto o mercado se encarrega escolher quais são os instrumentos mais interessantes e vantajosos"
\end{abstract}

Por outro lado, partindo do pressuposto de que o poder de controle pode criar incentivos para a expropriação de benefícios, refletindo-se em abuso para com a companhia e os demais acionistas, o anteprojeto da Lei $\mathrm{n}^{\mathrm{o}}$ 6.404/76 concebeu a figura do acionista controlador e, nos termos do artigo 117, este responderá pelos danos causados por atos praticados com abuso de poder.

Além disso, "o poder de controle na sociedade anônima, na medida em que constitui um "direito-função", é atribuído ao seu titular para a consecução de determinadas finalidades" ${ }^{36}$. Nos termos do artigo 116 da Lei $n^{\circ} 6.404 / 76$, o acionista controlador deve usar o poder de controle com

\footnotetext{
${ }^{34}$ FRAGOSO, Daniela Neves Reali. AKKERMAN, Gustavo. Op. Cit., pág. 294.

${ }^{35}$ Ibid., pág. 294.

${ }^{36}$ COMPARATO, Fabio Konder; SALOMÃO Filho, Calixto. O Poder de Controle na Sociedade Anônima. Rio de Janeiro: Forense, 2005, pág. 363.
} 
o fim de fazer a companhia realizar o seu objeto e cumprir sua função social. Como enuncia Carvalhosa:

\begin{abstract}
"O parágrafo único do art. 116 institui o dever fiduciário do controlador, cujo poder de governar autonomamente a companhia corresponde ao dever de fazê-lo visando à realização do seu objeto social, atendida a função social da empresa. Esse dever se estende à preservação dos direitos políticos e patrimoniais dos demais acionistas. O dever fiduciário dos controladores (...) decorre do poder de governar a sociedade autonomamente, sem o concurso, portanto, dos minoritários para a formação e a declaração da vontade social ${ }^{37}$.
\end{abstract}

Portanto, verifica-se que o legislador preocupou-se em atribuir deveres e funções ao acionista controlador, além das responsabilidades, visando evitar que os mecanismos de facilitação do poder de controle venham a ensejar ineficiência e/ou prejuízos para os demais acionistas e/ou a companhia. Assim expõe Carvalhosa:

\begin{abstract}
“A Lei n. 6.404/76, de 1976, ao instituir a figura do controlador, faz desaparecer o princípio da igualdade de todos os acionistas, já que são eles separados em duas categorias: controladores e minoritários. Institui com efeito, o controle como um órgão da companhia. Cria em consequência, o diploma de 1976 a responsabilidade do controlador, a par daquela dos acionistas em geral (art. 115) e dos administradores (arts. 153 a 159). Em consequência, são os controladores responsáveis pela estrita observância dos deveres de lealdade, de diligência e de transparência; são responsáveis por condutas que contrariem tais princípios, além de deverem abster-se de praticar atos e negócios com desvio de poder e em conflito de interesses com a companhia"38.
\end{abstract}

Percebe-se, assim que a Lei $n^{\circ}$ 6.404/76 foi concebida de modo a conciliar os interesses do empresário-empreendedor e do empresárioinvestidor, o qual terá a faculdade de suprimir suas prerrogativas políticas, caso não queira exercer o seu direito de voto, visando fortalecer suas vantagens patrimoniais. Destaca-se que, caso a companhia não cumpra a obrigação de lhe atribuir a vantagem patrimonial, conforme definido no estatuto social, as prerrogativas políticas devem ser restauradas, nos termos do artigo $111, \S 1^{\circ}$ da Lei $n^{\circ} 6.404 / 76$.

\footnotetext{
37 CARVALHOSA, Modesto. Comentários à Lei das Sociedades Anônimas. São Paulo: Saraiva,

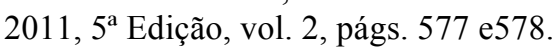

${ }^{38}$ Ibid., pág. 605.
} 
Por fim, destaca-se que se a companhia outorga vantagens e preferências inócuas ou seu controlador atua com abuso do poder de controle, o mercado irá considerar tais fatos na avaliação das ações da referida companhia, classificando-as como maus investimentos.

Portanto, a ação preferencial deve ser entendida como um “instrumento flexível e moldável à estruturação da composição do capital da companhia, conforme as necessidades e interesses dos envolvidos. Este instrumento tem o potencial de atrair o investidor (i) pela promessa de manutenção do controle, o que pode representar a principal motivação para a realização do investimento (conforme será abordado no Capítulo 5 do presente trabalho); (ii) de facilitar o controle nacional diante da entrada do capital estrangeiro no mercado brasileiro; e (iii) de atrair também as instituições que gerenciam recursos de terceiros, pelo retorno financeiro mais atrativo e dispensa de participação na condução das decisões de negócios" ${ }^{39}$.

\subsection{Da Regulação no Estatuto}

Nos termos do artigo 19 da Lei $\mathrm{n}^{\mathrm{o}}$ 6.404/76, o estatuto da companhia emissora de ações preferenciais deve declarar as preferências atribuídas à cada classe de ações, bem como as restrições a que ficarem sujeitas.

Além disso, conforme disposto no artigo $17, \S 2^{\circ}$ da Lei ${ }^{\circ}$ 6.404/76, o estatuto deve esmiuçar quaisquer outras preferências atribuídas aos acionistas sem direito ou com limitação do exercício do voto, além daquelas previstas no caput do artigo 17 da Lei ${ }^{\circ}$ 6.404/76. Nas palavras de Eizirik:

\footnotetext{
${ }^{39}$ FRAGOSO, Daniela Neves Reali. AKKERMAN, Gustavo. Op. Cit., pág. 295.
} 
"Com base nos artigos 17 e 18, várias combinações podem ser feitas entre as diversas classes de ações preferenciais existentes na companhia, razão pela qual deverão constar do estatuto, de forma clara e precisa, as vantagens, direitos e preferências atribuidos a cada classe de ações preferenciais, sejam de ordem patrimonial ou política" ${ }^{, 40}$.

Assim sendo, "se o estatuto social cria ações que denomina preferenciais, mas enuncia suas vantagens de modo impreciso ou incompleto, ou tais vantagens serão indeterminadas e indetermináveis, ou seu conteúdo pode ser modificado por deliberação da assembleia geral, tendo em vista que tais ações não satisfazem os requisitos legais para serem conceituadas como preferenciais, nos termos do artigo 19 da Lei $\mathrm{n}^{0}$ $6.404 / 76$, e não lhes pode ser, portanto, negado o direito de voto"41.

Nos termos da redação atual do artigo 17 da Lei $n^{0}$ 6.404/76, as vantagens patrimoniais que podem ser conferidas às ações preferenciais sem direito de voto ou com restrições consistem em: (i) prioridade na distribuição de dividendo, fixo ou mínimo; (ii) prioridade no reembolso de capital, com prêmio ou sem ele; (iii) direito de participar do dividendo a ser distribuído, correspondente a, pelo menos, $25 \%$ do lucro líquido do exercício, calculado na forma do artigo 202 da Lei $n^{\circ} 6.404 / 76$, de acordo com o seguinte critério: (a) prioridade no recebimento do dividendo correspondente a, no mínimo, 3\% do valor de patrimônio líquido da ação; e (b) direito de participar, em igualdade de condições com ações ordinárias, do lucro distribuído que remanescer depois de assegurado, às ações ordinárias, dividendo igual ao mínimo prioritário; (iv) direito ao recebimento de dividendo, por ação preferencial, pelo menos $10 \%$ maior que o atribuído a cada ação ordinária; e (v) direito de serem incluídas na oferta pública de alienação de controle, nos termos do artigo 254-A da Lei

\footnotetext{
${ }^{40}$ EIZIRIK, Nelson. A Lei das S/A Comentada. São Paulo: Quartier Latin do Brasil, 2011, vol. I, pág. 177.

${ }^{41}$ LAMY, Alfredo; PEDREIRA, José Luiz Bulhões. Op. Cit., pág. 249 e 250.
} 
$\mathrm{n}^{\mathrm{o}}$ 6.404/76, assegurado o dividendo pelo menos igual ao das ações ordinárias.

Convém destacar que, com a reforma perpetrada pela Lei $\mathrm{n}^{\mathrm{o}}$ 10.303/01, "as ações preferenciais sem direito de voto ou com restrições somente serão admitidas à negociação no mercado de valores mobiliários se a elas for atribuída, além do eventual direito de prioridade no reembolso do capital, ao menos, uma das seguintes vantagens, nos termos do $\S 1^{\circ}$ do artigo 17 da Lei $\mathrm{n}^{\circ}$ 6.404/76: (i) direito a dividendo correspondente a, no mínimo $25 \%$ do lucro líquido do exercício; (ii) direito a dividendo ao menos $10 \%$ superior ao recebido pelas ações ordinárias; ou (iii) direito de inclusão na oferta pública de alienação de controle" ${ }^{, 42}$.

Por seu turno, o artigo 19 da Lei $\mathrm{n}^{\circ}$ 6.404/76 enuncia que o estatuto social poderá prever o resgate ou amortização, a conversão de ações de uma classe em ação de outra e em ações ordinárias, e destas em preferenciais, fixando as respectivas condições.

"As ações preferenciais resgatáveis conferem ao seu titular o direito de receber da companhia o pagamento pelo seu valor, retirando-as de circulação, com redução ou não do capital social. Já as ações preferenciais amortizáveis conferem ao acionista, antecipadamente, o direito ao recebimento do montante que lhe seria atribuído em caso de liquidação da companhia. Por fim, as ações preferenciais conversíveis consistem em ações que podem ser convertidas em outra classe também de preferenciais ou, ainda, em ações ordinárias" ${ }^{43}$.

\footnotetext{
${ }^{42}$ EIZIRIK, Nelson. Op. Cit., pág. 163.

${ }^{43}$ CARVALHOSA, Modesto. Comentários à Lei das Sociedades Anônimas, vol. 1, págs. $339 \mathrm{e}$ 340.
} 
No que tange às vantagens políticas, nos termos do artigo 18 caput $\mathrm{e}$ parágrafo único da Lei $\mathrm{n}^{\mathrm{o}} 6.404 / 76$, o estatuto pode (i) assegurar a uma ou mais classes de ações preferenciais o direito de eleger, em votação em separado, um ou mais membros dos órgãos de administração, bem como (ii) subordinar as alterações estatutárias que especificar à aprovação, em assembleia especial, dos titulares de uma ou mais classes de ações preferenciais.

Convém destacar que as vantagens ou preferências atribuídas no estatuto social às ações preferenciais somente poderão ser modificadas mediante deliberação dos titulares de tais ações, nos termos do artigo 136, $\S 1^{\circ}$ da Lei $n^{\circ} 6.404 / 76$, a não ser que o estatuto social tenha previsto tais modificações.

Dispõe o artigo $136 \S^{\circ}$ da Lei $n^{\circ} 6.404 / 76$ que a eficácia da deliberação da assembleia geral que versar sobre a: (i) criação de ações preferenciais ou aumento de classe de ações preferenciais existentes, sem guardar proporção com as demais classes de ações preferenciais; ou (ii) alteração nas preferências, vantagens e condições de resgate ou amortização de uma ou mais classe de ações preferenciais, ou a criação de nova classe mais favorecida; depende de prévia aprovação ou ratificação, em prazo improrrogável de um ano, por titulares de mais da metade de cada classe de ações preferenciais prejudicadas, reunidos em assembleia especial convocada pelos administradores e instalada com as formalidades legais.

Como ressalta Carvalhosa, "tais decisões requerem quórum qualificado de instalação na medida em que a deliberação válida dependa de aprovação de maioria absoluta das preferenciais em geral ou da 
respectiva classe e não da maioria dos acionistas presentes à assembleia" 44 .

Por fim, nos termos do artigo 137 da Lei $n^{\circ}$ 6.404/76, a aprovação das matérias elencadas acima, dá ao acionista preferencial dissidente o direito de retirar-se da companhia, mediante o reembolso do valor das suas ações (de acordo com o enunciado do artigo 45 da Lei $n^{\circ}$ 6.404/76), ressaltando-se que somente terá direito de retirada o acionista prejudicados, pois, como bem ressalta Müssnich, "o direito de recesso não é, em essência, um direito que possa ser exercido livremente, impondo-se ao acionista dissidente o ônus de provar os prejuízos, efetivos ou potenciais, causados pela medida contra a qual se insurge"45.

\footnotetext{
${ }^{44}$ Ibid., pág. 332.

${ }^{45}$ MÜSSNICH, Francisco Antunes Maciel. Reflexões Sobre o Direito de Recesso na Lei das Sociedades por Ações. In Reforma da Lei das Sociedades Anônimas. Jorge Lobo (Coord.). Rio de Janeiro: Forense, $2^{\mathrm{a}}$ Edição, 2002, pág. 285.
} 


\section{Vantagens e Preferências Atribuíveis às Ações Preferenciais sem Direito a Voto ou com Restrições}

\subsection{Das Preferências Relativas à Distribuição de Dividendos}

Inicialmente, a única vantagem patrimonial referente à distribuição de dividendos prevista no ordenamento jurídico brasileiro era a prioridade em sua distribuição. Com o advento da Lei ${ }^{\circ}$ 9.457/97, estabeleceu-se o direito ao dividendo de, no mínimo, $10 \%$ maior daquele atribuído às ações ordinárias, vantagem que foi mantida pela Lei $\mathrm{n}^{\circ} 10.303 / 01$.

"Prioridade na distribuição de dividendo consiste em atribuir às ações preferenciais o direito a, em cada exercício, dividendo fixo ou mínimo antes que qualquer dividendo seja distribuído às ações ordinárias $^{46 "}$. Desse modo, após a apuração do lucro líquido do exercício social, a companhia deverá destiná-lo, primeiramente, ao pagamento do dividendo das ações preferenciais, de modo que apenas o lucro remanescente será destinado ao pagamento do dividendo das ações ordinárias.

A primeira vista, a preferência na distribuição de dividendos pode não parecer uma vantagem relevante $\mathrm{e}$, realmente, enquanto a companhia aufere lucro líquido suficiente para o pagamento do dividendo das ações preferenciais e ordinárias, não há vantagem prática para os acionistas preferenciais. Entretanto, na medida em que companhia não consegue auferir lucro líquido suficiente para o pagamento do dividendo das ações preferenciais e ordinárias, aos acionistas preferenciais será garantido, conforme o caso, o direito ao recebimento do dividendo fixo ou mínimo.

${ }^{46}$ LAMY, Alfredo; PEDREIRA, José Luiz Bulhões. Op. Cit., pág. 252. 
Assim, às ações ordinárias, será atribuído apenas o remanescente, se houver (quando todo lucro líquido apurado for utilizado para o pagamento do dividendo prioritário).

Por dividendo fixo, entende-se aquele que é pré-estabelecido no estatuto social da companhia, o qual pode representar uma porcentagem do valor nominal da ação, se houver, ou um determinado valor fixado em reais, se as ações não tiverem valor nominal. Desse modo, ao acionista preferencial com direito ao recebimento de dividendo fixo, apenas será atribuído o lucro líquido suficiente ao pagamento do valor fixado no estatuto à este título, sem participar, portanto, do lucro líquido remanescente. Como explica Eizirik:

\begin{abstract}
"Dividendo fixo é a quantia do lucro previamente quantificada no estatuto social que deve ser atribuída a cada ação preferencial com base em (i) um valor certo em reais; ou (ii) percentual determinado do valor nominal da ação preferencial ou, caso as ações não tenham valor nominal, sobre o próprio capital social, ou ainda, do patrimônio líquido da companhia. As ações com dividendo fixo só participam do lucro até o montante estatutariamente predeterminado, ou seja, não participam do lucro remanescente que será integralmente atribuído às ações preferenciais de outra classe eventualmente existente e às ações ordinárias. Os dividendos fixo, portanto, assemelham-se a um juro pré-fixado que é garantido aos acionistas sobre o capital por eles investido, porém sujeito à condição de que a companhia tenha lucro suficiente para pagá-los"47.
\end{abstract}

Dificilmente uma ação preferencial com direito ao recebimento de dividendo fixo obteria sucesso na capitação de recursos no mercado de capitais. Como bem elucidam Bulhões e Lamy:

"(...) o dividendo fixo tem (...) a significação econômica de juro fixo porém sujeito à condição de que a companhia realize lucro suficiente para pagá-lo. A ação com estas características não é instrumento para captar recursos no mercado, mas serve para compor interesses de grupos associados em companhias fechadas ou joint ventures, ou na reorganização de companhias em estado pré-falimentar, quando credores convertem seus créditos em ações e o dividendo fixo substitui os juros a que tinham direito" ${ }^{\prime 48}$.

\footnotetext{
${ }^{47}$ EIZIRIK, Op. Cit., pág. 156 e 157.

${ }^{48}$ LAMY, Alfredo; PEDREIRA, José Luiz Bulhões. Op. Cit., pág. 254.
} 
Por sua vez, o direito ao recebimento de dividendo mínimo consiste em receber (i) prioritariamente, o lucro líquido auferido pela companhia em determinado exercício social, até o montante estabelecido como mínimo; e (ii) em igualdade de condições com os acionistas titulares de ações ordinárias, o lucro líquido remanescente, nos termos do $\S 4^{\circ}$ do artigo 17 da Lei $n^{\circ} 6.404 / 76$. Nas palavras de Eizirik:

"O dividendo mínimo, por sua vez, é aquele previamente definido no estatuto social, com base nos mesmos critérios de cálculo do dividendo fixo (...) e que dá ao titular da ação preferencial o direito de receber prioritariamente uma parcela do lucro. Salvo disposição estatutária em contrário, somente após a atribuição do dividendo mínimo às ações preferenciais de determinada classe, igual valor deverá ser atribuido às ações ordinárias e às demais preferenciais, de outra classe, eventualmente existente; o saldo remanescente do lucro, se houver, será partilhado entre as ações ordinárias e preferenciais em igualdade de condições $^{\prime \prime 4}$.

Assim como o dividendo fixo, caso a ação tenha valor nominal, o dividendo mínimo representará uma porcentagem deste valor; do contrário, caso a ação não tenha valor nominal, o estatuto deverá estabelecer o montante expresso em reais ${ }^{50}$ à título de dividendo mínimo por exercício social ou semestre.

Convém destacar que, garantir a prioridade na distribuição do dividendo não significa garantir o recebimento de dividendo. De acordo com o disposto no artigo 201 da Lei $n^{\circ}$ 6.404/76, a companhia somente pode pagar dividendos à conta de lucro líquido do exercício, de lucro acumulados e de reserva de lucros; bem como à conta de reserva de capital, no caso das ações preferenciais de que trata o $\S 5^{\circ}$ do artigo 17 da Lei $n^{o}$ 6.040/76, de modo que a distribuição de dividendos efetuada de modo contrário implicará na responsabilização solidária dos administradores e

\footnotetext{
${ }^{49}$ EIZIRIK, Nelson. Op. Cit., pág. 157.

${ }^{50} \mathrm{Em}$ razão do contexto histórico em que a Lei $\mathrm{n}^{\mathrm{0}}$ 6.404/76 foi promulgada, de elevada inflação, verifica-se a preocupação do legislador em resguardar o valor do dividendo fixo ou mínimo a ser distribuído para o titular da ação sem valor nominal, conforme o disposto no $\S 3^{\circ}$ do artigo 17 da Lei $\mathrm{n}^{\mathrm{o}} 6.404 / 76$, o qual estabelece que o montante fixado será atualizado monetariamente, por ocasião da assembleia geral ordinária.
} 
conselheiros fiscais, os quais deverão repor à caixa social a importância distribuída.

Nesse sentido, "o dividendo prioritário das ações preferenciais, ainda que fixo ou cumulativo, não poderá ser distribuído em prejuízo do capital social, salvo quando, em caso de liquidação da companhia, essa vantagem tiver sido expressamente assegurada, nos termos do $\$ 3^{\circ}$ do artigo 17 da Lei $\mathrm{n}^{\mathrm{o}} 6.404 / 76$, pois nesse caso, o dividendo não prejudica os credores, que serão pagos no processo de liquidação da companhia antes de qualquer rateio do acervo líquido" ${ }^{51}$.

Os dispositivos legais supramencionados consagram o princípio da intangibilidade do capital social, o qual "impede a distribuição de dividendos se a sociedade não produziu lucro, tendo em vista a proteção de terceiros (credores)" ${ }^{52}$. Desse modo, "os acionistas não podem corroer o capital social com o recebimento de dividendos, pois uma vez esvaído o capital social, dada a limitação de responsabilidade dos acionistas à perda da participação na sociedade de cada um, os credores sociais seriam prejudicados com o não recebimento dos seus créditos; ou seja, a garantia dos credores (capital social) desapareceria com a satisfação reiterada dos dividendos, sem que houvesse a apuração de lucros pela companhia" ${ }^{53}$.

Caso o estatuto social garanta à ação preferencial o direito ao dividendo cumulativo, o dividendo fixo ou mínimo que não for pago em um determinado exercício social, por insuficiência de lucro líquido, será acumulado àquele devido no exercício social seguinte, de modo que, na medida em que a companhia volte a auferir lucro líquido, o titular da ação preferencial receberá integralmente tais dividendos.

\footnotetext{
${ }^{51}$ LAMY, Alfredo; PEDREIRA, José Luiz Bulhões. Op. Cit., págs. 256 e 257.

${ }^{52}$ CARVALHOSA, Modesto. Op. Cit., 225.

${ }^{53}$ DA COSTA, Philomeno J. Anotação às Companhias. Revista dos Tribunais, 1980, vol. I, pág. 299.
} 
Conforme destaca Lucena, "a Lei n ${ }^{\circ}$ 6.404/76 não indicou elementos suficientes para compor o conceito de dividendos cumulativos, o qual deve ser concebido de acordo com o sistema criado a respeito dos dividendos e das preferências e vantagens outorgadas às ações preferenciais, consistindo, portanto, nos dividendos não pagos no exercício em que o lucro for insuficiente, acumulando-se para pagamento no exercício em que a companhia aufira lucros suficientes a satisfazê-los" ${ }^{54}$.

Destaca-se que o artigo 203 da Lei $\mathrm{n}^{\circ}$ 6.404/76 reforça o direito à prioridade dos acionistas preferenciais, ao dispor que a formação de reservas, exceto a legal, bem como a distribuição do dividendo obrigatório, não prejudicará o direito dos acionistas preferenciais de receber os dividendos fixos ou mínimos a que tenham prioridade, inclusive os atrasados, se cumulativos.

Por sua vez, atribuir dividendo diferenciado às ações preferenciais consiste em garantir, apenas, o direito ao recebimento de dividendo superior àquele a ser distribuído às ações ordinárias, sem garantir, contudo, a prioridade na sua distribuição.

Assim sendo, caso a companhia venha a auferir lucro líquido insuficiente, todos os acionistas arcarão proporcionalmente com o ônus da redução ou perda de dividendo, conforme o caso, e não somente os acionistas ordinários.

Desse modo, verifica-se que a atribuição do direito ao dividendo diferenciado às ações preferenciais representa um risco inferior para os

\footnotetext{
${ }^{54}$ LUCENA, José Waldecy. Das Sociedades Anônimas - Comentários à Lei. Rio de Janeiro: Renovar, 2009, vol. 1, pág. 280.
} 
acionistas ordinários do que a atribuição do direito ao dividendo prioritário. Nesse sentido, esclarecem Bulhões e Lamy:

"Nos periodos de lucro reduzido, todos os acionistas continuarão a receber dividendos, embora os titulares de ações preferenciais recebam dividendo um pouco maior do que o das ações ordinárias; mas não haverá o risco - que existe se o dividendo é prioritário - de que os titulares de ações ordinárias não recebam nenhum dividendo porque todo o lucro é utilizado para pagar o dividendo prioritário" ${ }^{\prime \prime 5}$.

Ainda, destaca-se que, nos termos do $\S 1^{\circ}$ do artigo 111 da Lei $\mathrm{n}^{\mathrm{o}} 6.404 / 76$, caso a companhia deixe de realizar o pagamento, durante três exercícios sociais consecutivos (se o estatuto não estabelecer um período inferior), do dividendo prioritário fixo ou mínimo, será atribuído o direito de voto às ações preferenciais não votantes ou serão suspensas as restrições ao exercício do direito de voto, conforme o caso.

Em que pese a controvérsia doutrinária sobre a aplicação destes dispositivos legais às ações preferenciais com direito ao dividendo diferenciado, tendo em vista que Bulhões e Lamy defendem a sua inaplicabilidade, estes sustentam que "inexiste o risco (de aquisição do direito de voto ou suspensão das restrições, em razão do inadimplemento da companhia) para os acionistas ordinários, caso somente seja atribuído o direito ao dividendo diferenciado para as ações preferenciais" ${ }^{, 56}$.

Com o advento da Lei $n^{0} 10.303 / 01$, estabeleceu-se, por meio do inciso $\mathrm{I}$ ao $\S 1^{\circ}$ do artigo 17 da Lei $\mathrm{n}^{\circ}$ 6.404/76, uma nova opção de vantagem a ser atribuída às ações preferenciais para que possam ser admitidas à negociação no mercado de valores mobiliários, a qual consiste na prioridade no recebimento de dividendo mínimo de $3 \%$ do valor patrimonial da ação correspondente a, no mínimo, 25\% do lucro líquido apurado pela companhia, apurado conforme o artigo 202 da Lei $\mathrm{n}^{\mathrm{o}}$

\footnotetext{
${ }^{55}$ LAMY, Alfredo; PEDREIRA, José Luiz Bulhões. Op. Cit., pág. 253.

${ }^{56}$ Ibid., pág. 253.
} 
6.404/76. Nesse sentido, no entendimento de Bulhões e Lamy "a base de cálculo da prioridade é determinada, tal como o dividendo obrigatório, nos termos do artigo 202 da Lei 6.404/76, mas não é necessariamente igual à porcentagem do dividendo obrigatório, que pode ser outra" ${ }^{57}$.

Desse modo, os dividendos serão atribuídos (i) primeiramente, aos acionistas preferenciais com a vantagem mencionada acima, aos quais será realizado o pagamento de $3 \%$ (ou montante superior, conforme previsto no estatuto) sobre o valor de patrimônio líquido da ação, limitados a 25\% (ou montante superior, conforme previsto no estatuto) do lucro líquido auferido pela companhia; (ii) em segundo lugar, aos acionistas ordinários para pagamento de dividendo igual ao recebido pelas ações preferenciais; e (iii) em terceiro lugar, aos acionistas preferenciais e ordinários, em igualdade de condições, se houver lucros remanescentes.

Eizirik destaca que:

"As preferências previstas nas alineas " $a$ " e " $b$ " do inciso I do $\$ 1^{\circ}$ do artigo 17 da Lei $n^{\circ}$ 6.404/76 são cumulativas, isto é: o acionista terá prioridade no recebimento de ao menos 3\% (três por cento) sobre o valor do patrimônio líquido da ação e mais o direito de participar dos lucros eventualmente remanescentes em igualdade de condições com as ordinárias, depois de assegurado a estas dividendo igual ao mínimo. Ou seja, não há, nesse caso, dividendo fixo; trata-se de dividendo mínimo, pois essas ações têm o direito de participar no saldo dos lucros eventualmente remanescentes, após assegurado às ações ordinárias um dividendo igual a esse mínimo" ${ }^{158}$.

Conforme dito anteriormente, o princípio da intangibilidade do capital social impede que o dividendo prioritário das ações preferenciais seja distribuído em prejuízo do capital social, a não ser na hipótese do $\S 3^{\circ}$ do artigo 17 da Lei $\mathrm{n}^{0}$ 6.404/76. Nesse sentido, "o princípio da intangibilidade do capital social não prevalece para a companhia em liquidação, se houver disposição estatutária, pois, neste caso, os credores

\footnotetext{
${ }^{57}$ Ibid., pág. 256.

${ }^{58}$ EIZIRIK, Nelson. Op. Cit., pág. 163 e 164.
} 
não são prejudicados, uma vez que receberão seus créditos no processo de liquidação antes do rateio do acervo líquido" ${ }^{59}$.

Contudo, há uma exceção ao princípio da intangibilidade do capital social, conforme disposto no $\S 6^{\circ}$ do artigo 17 da Lei $n^{\circ} 6.404 / 76$, o qual enuncia que o estatuto pode conferir às ações preferenciais com prioridade na distribuição de dividendo cumulativo, o direito de recebê-lo, no exercício em que o lucro for insuficiente, à conta das reservas de capital de que trata o $\S 1^{\circ}$ do artigo 182 da Lei ${ }^{\circ} 6.404 / 76$ (reserva de capital).

Nos termos do referido dispositivo legal, serão classificadas como reservas de capital as contas que registrarem (i) a contribuição do subscritor de ações que ultrapassar o valor nominal e a parte do preço de emissão das ações sem valor nominal que ultrapassar a importância destinada à formação do capital social, inclusive nos casos de conversão em ações de debêntures ou partes beneficiárias; (ii) o produto da alienação de partes beneficiárias e bônus de subscrição; e (iii) o resultado da correção monetária do capital realizado, enquanto não-capitalizado.

Ou seja, "as reservas de capital visam reforçar o capital da companhia, sendo constituídas com por contribuições de acionistas ou de terceiros para o patrimônio líquido da sociedade, a saber (i) ágio na emissão de ações, o qual consiste na contribuição do subscritor que ultrapassa o valor nominal das ações ou, no caso de ações sem valor nominal, a parte do preço de emissão que ultrapassa a importância destinada à formação do capital social; e (ii) o produto da alienação de partes beneficiárias e de bônus de subscrição"60.

\footnotetext{
${ }^{59}$ Ibid., pág. 167 e 168.

${ }^{60}$ EIZIRIK, Nelson. A Lei das S/A Comentada, vol. III, pág. 76.
} 
Nesse sentido, verifica-se que as reservas de capital objetivam, precipuamente, reduzir o risco de insolvência da companhia. Porém, estas não devem ser confundidas com o capital social, o qual tem a finalidade precípua de garantir o pagamento aos credores da companhia.

Assim sendo, por mais que as reservas de capital tenham a função de reduzir o risco de insolvência, estas não servem de garantia aos credores e, portanto, podem ser destinadas aos acionistas da companhia, por meio de compra de ações, resgate ou reembolso, além de poderem ser distribuídas, à título de dividendo, para os acionistas preferenciais com prioridade na distribuição de dividendo cumulativo, caso o lucro líquido apurado pela companhia não seja suficiente. Nesse sentido, Eizirik destaca que:

\begin{abstract}
"As reservas de capital somente podem ser distribuídas aos sócios em caráter excepcional, na hipótese de os demais fundos legalmente previstos (lucros do exercício e reserva de lucros) não serem suficientes para cobrir o valor de dividendos cumulativos ( $\$ 6^{\circ}$ do artigo 17). De acordo com o artigo 201, ressalvada a hipótese do $\S 6^{\circ}$ do artigo 17 , a companhia somente pode pagar dividendo à conta de lucro líquido do exercício e de reservas de lucros ${ }^{\prime \prime 61}$.
\end{abstract}

Outra vantagem patrimonial que pode ser atribuída às ações preferenciais, criada pela Lei $n^{\circ}$ 9.457/97, consiste no recebimento de dividendo, ao menos, $10 \%$ superior àquele atribuído para cada ação ordinária. Entretanto, apesar de ser garantido um dividendo superior às ações preferenciais, neste caso, não é assegurada a prioridade na sua distribuição, ou seja, os acionistas preferenciais não terão a vantagem de receber todo o lucro da companhia antes da sua distribuição aos acionistas ordinários. Conforme esclarece Carvalhosa:

"Esse tipo de vantagem já era previsto pela Lei $n .9457$, de 1997, mas tinha
caráter obrigatório para quaisquer ações preferenciais, desde que os estatutos
da companhia não estabelecessem para tais ações sem voto dividendos fixos ou
mínimos. Pela nova redação do \$1 $1^{\circ}$ do novo art. 17, trazida pela Lei n.
10.303/2001, esse tipo de privilégio passa a ser atribuído apenas para as ações
preferenciais negociadas no MVM [mercado de valores mobiliários], e, mesmo

${ }^{61}$ EIZIRIK, A Lei das S/A Comentada, vol. I, pág. 77. 
nesse caso, trata-se de uma das três alterativas estatutárias possiveis de privilégios mínimos que o $\$ 1^{\circ}$ do novo art. 17 faculta à companhia escolher ${ }^{\prime \prime 2}$.

\subsection{Outras Preferências ou Vantagens Patrimoniais}

Nos termos do artigo 109, II da Lei $\mathrm{n}^{\circ}$ 6.404/76, nem o estatuto social, nem a assembleia geral poderão privar o acionista do direito de participar do acervo líquido da companhia, em caso de sua liquidação.

Caso a companhia somente tenha emitido ações ordinárias, ou ações preferenciais sem direito à preferência no reembolso do capital, todos os seus acionistas irão participar, em igualdade de condições, do acervo apurado após a liquidação. Todavia, caso a companhia tenha emitido ações preferenciais com direito à prioridade de recebimento do reembolso de capital, o acervo apurado após a liquidação será rateado, primeiramente, entre os acionistas preferenciais com atribuição da referida vantagem e, o acervo líquido remanescente, se houver, será destinado aos demais acionistas. Nesse sentido, Eizirik esclarece que:

"(...) sendo estabelecida como vantagem das ações preferenciais a prioridade no reembolso do capital, o acervo líquido será rateado, em primeiro lugar, para essas ações e apenas o saldo remanescente será atribuído às demais ações. Portanto, se o acervo líquido for suficiente para reembolsar apenas essas ações, os demais acionistas não recebem reembolso de capital ${ }^{\prime \prime 3}$.

Convém destacar que, caso as ações preferenciais com prioridade no reembolso de capital tenham valor nominal, basta que o estatuto social preveja a referida vantagem, de modo que o montante do capital social a ser reembolsado será aquele correspondente ao valor nominal da ação. Contudo, caso as ações preferenciais com prioridade no reembolso de capital não tenham valor nominal, o estatuto social deve fixar qual será o montante a ser prioritariamente reembolsado, "sob pena de não satisfazer ao

\footnotetext{
${ }^{62}$ CARVALHOSA, Modesto. Op. Cit., pág. 303.

${ }^{63}$ Ibid., pág. 160 e 161.
} 
requisito legal sobre a estipulação das vantagens ou preferências da ação preferencial" $^{64}$.

Além do valor do reembolso, o II do artigo 17 da Lei n ${ }^{\circ}$ 6.404/76 admite a possibilidade de ser atribuído um prêmio no reembolso às ações preferenciais, o qual é estabelecido por meio de disposição estatutária no sentido de que a "devolução de capital ao acionista consistirá em valor superior ao valor da ação, representando assim a diferença entre o valor da ação e o valor que o acionista vier a receber"65.

Bulhões e Lamy enunciam que "se as ações têm valor nominal, o prêmio pode ser fixado como uma porcentagem desse valor ou em quantidade de moeda; se não têm valor nominal, o prêmio deve ser fixado em quantidade de moeda" ${ }^{\prime 66}$.

Também pode ser atribuída às ações preferenciais, o direito de serem incluídas na oferta pública de alienação de controle, nas condições previstas no artigo 254-A da Lei $\mathrm{n}^{\circ}$ 6.404/76, assegurado o dividendo pelo menos igual ao das ações ordinárias.

$\mathrm{O}$ artigo 254-A da Lei $\mathrm{n}^{\circ}$ 6.404/76 dispõe que a alienação, direta ou indireta, do controle de companhia aberta somente poderá ser contratada sob a condição suspensiva ou resolutiva, de que o adquirente se obrigue a fazer oferta pública de aquisição de ações com direito de voto de propriedade dos demais acionistas da companhia, de modo a lhes assegurar o preço no mínimo igual a $80 \%$ do valor pago por ação com direito a voto, integrante do bloco de controle.

\footnotetext{
${ }^{64}$ LAMY, Alfredo; PEDREIRA, José Luiz Bulhões. Op. Cit., pág. 258.

${ }^{65}$ EIZIRIK, Nelson. Op. Cit., pág. 162.

${ }^{66}$ LAMY, Alfredo; PEDREIRA, José Luiz Bulhões. Op. Cit., págs. 259.
} 
Assim sendo, "tal como para as ações ordinárias não integrantes do bloco de controle, deverá ser oferecido às ações preferenciais titulares desta vantagem, um preço de aquisição de no mínimo igual a $80 \%$ do valor ofertado às ações ordinárias que integram o bloco de controle" 67 .

Portanto, uma vez outorgada a vantagem constante no II do artigo 17 da Lei $\mathrm{n}^{\mathrm{o}}$ 6.404/76, o ofertante que objetiva adquirir o controle da companhia deverá estender a oferta a tais ações preferenciais, conforme previsto no estatuto social da companhia.

Por fim, o $\S 2^{\circ}$ do artigo 17 da Lei $n^{\circ}$ 6.404/76 enuncia que deverão constar no estatuto social, com precisão e minúcia, outras preferências ou vantagens que sejam atribuídas aos acionistas sem direito a voto, ou com voto restrito, além das descritas acima.

Tradicionalmente, à luz do Decreto $n^{\circ} 21.256 / 32$, do Decreto-lei $n^{o}$ 2.627/40 e da redação original do artigo 17 caput da Lei $n^{\circ}$ 6.404/76, a atribuição de vantagens ou preferências às ações preferenciais devia ser realizada de modo restritivo, ou seja, somente poderiam ser atribuídas as preferências ou vantagens previstas em lei. Entretanto, com o advento da Lei $n^{\circ} 10.303 / 01$ e a inclusão do $\S 2^{\circ}$ ao artigo 17 da Lei no 6.404/76, há margem para uma interpretação distinta, conforme esclarece Eizirik:

\footnotetext{
"O $\S 2^{\circ}$ confere ampla autonomia para que o estatuto defina as preferências ou vantagens adicionais às legalmente previstas para as ações preferenciais sem direito de voto ou com restrição ao exercício desse direito, desde que estas constem do seu texto com precisão e minúcia. Dessa forma, as preferências ou vantagens elencadas neste artigo não são exaustivas, ou seja, outras preferências elencadas além das previstas no caput e nos incisos I, II e III, $\$ 1^{\circ}$, poderão ser conferidas às ações preferenciais sem direito de voto, tanto no caso daquelas negociadas no mercado de valores mobiliários como daquelas não negociadas" ${ }^{\prime \prime}$.
}

\footnotetext{
${ }^{67}$ CARVALHOSA, Modesto. Op. Cit., pág. 206.

${ }^{68}$ EIZIRIK, Nelson. Op. Cit., pág. 167.
} 
Desse modo, ao admitir que outras vantagens ou preferências sejam atribuídas às ações preferenciais sem direito a voto, ou com voto restrito, desde que descritas com precisão e minúcia no estatuto social, o $\S 2^{\circ}$ do artigo 17 da Lei $n^{\circ}$ 6.404/76 consagra uma interpretação exemplificativa para as vantagens ou preferências previstas no âmbito da Lei $n^{\circ}$ 6404/76, desde que observados os requisitos mínimos para a supressão ou restrição do direito de voto, bem como para a negociação de tais ações no mercado de valores mobiliários, conforme o caso.

\subsection{Das Preferências Políticas ou Administrativas}

O Decreto-lei $n^{\circ} 2.627 / 40$ era omisso no tocante à conferência de vantagens políticas às ações preferenciais. Contudo, a Exposição de Motivos que acompanhou o anteprojeto da Lei $n^{0}$ 6.404/76 estabeleceu que “o seu artigo 18, sancionando práticas usuais, inclusive nas participações do BNDE (antigo Banco Nacional do Desenvolvimento Econômico e Social), autoriza a atribuição à determinada classe de ações preferenciais o direito de eleger representante nos órgãos de administração e o poder de veto em modificações estatutárias" ${ }^{69}$, tendo em vista que o BNDE exigia ações preferenciais com vantagens políticas para financiar investimentos ou adquirir participações societárias.

Em relação à conferência de vantagens políticas às ações preferenciais, boa parte da doutrina brasileira sustenta que tais vantagens devem ser atribuídas de modo suplementar às vantagens patrimoniais, ou seja, de acordo com a maioria da doutrina, o atual ordenamento jurídico brasileiro não contempla a criação de ações preferenciais dotadas, exclusivamente, de vantagens políticas.

\footnotetext{
${ }^{69}$ Exposição de Motivos $\mathrm{N}^{\mathrm{o}} 196$, de 24 de junho de 1976, relativa ao anteprojeto da Lei $\mathrm{n}^{\mathrm{o}}$ $6.404 / 76$.
} 
Nesse sentido, enunciam Bulhões e Lamy que:

"As vantagens patrimoniais da ação preferencial sempre foram concebidas como contrapartida da eliminação ou restrição do direito de voto. Parece-nos que as vantagens políticas são admitidas na Lei [ $\mathrm{n}^{\circ}$ 6.404/76] como acréscimo às vantagens patrimoniais, e que não se ajusta ao sistema da lei uma ação preferencial que somente tenha vantagens politicas ${ }^{\prime 70}$.

Defendendo o mesmo entendimento, Eizirik expõe que:

"Essas vantagens são admitidas como acréscimo às vantagens patrimoniais; no regime societário brasileiro não podem existir ações preferenciais que tenham apenas vantagens políticas. A emissão das preferenciais sem direito a voto pressupõe a atribuição de uma vantagem de natureza patrimonial ou econômica, vis-à-vis as ações ordinárias, como forma de compensar seus titulares pela não participação no poder político da companhia. Não existe ação preferencial sem a atribuição de uma vantagem patrimonial ao acionista, visto que a subtração do direito de voto só é possivel enquanto compensada por um privilégio econômico, na repartição dos lucros ou no reembolso de capital," ${ }^{, 1}$.

Em sentido contrário, Leães entende que "não se sustentam os argumentos que impedem a criação de ações preferenciais exclusivamente dotadas de privilégios ou vantagens políticas ou administrativas, em razão, principalmente, de não haver nenhuma disposição na Lei no 6.404/76 expressamente vedando à emissão de tais ações preferenciais e, assim, amparada pelo princípio da autonomia da vontade, a companhia poderia emitir ações preferenciais dotadas, exclusivamente, de vantagens políticas" $" 72$.

Ressalvada a discussão sobre as ações preferenciais dotadas, exclusivamente, de vantagens políticas, o artigo 18 da Lei $\mathrm{n}^{\circ}$ 6.404/76 prevê que o estatuto social pode assegurar, a uma ou mais classes de ações preferenciais, o direito de eleger, em votação em separado, um ou mais membros dos órgãos de administração da companhia. Nesse sentido, Lucena explica que:

\footnotetext{
${ }^{70}$ LAMY, Alfredo; PEDREIRA, José Luiz Bulhões. Op. Cit., pág. 260.

${ }^{71}$ EIZIRIK, Nelson. Op. Cit., págs. 175 e 176.

${ }^{72}$ LEÃES, Luiz Gastão Paes de Barros. Op. Cit., pág. 843, 844 e 845.
} 
"O estatuto (...) há de expressamente regular a que classe ou classe de ações preferenciais é concedido o privilégio, bem assim quais os membros que serão eleitos, se da diretoria, se do conselho de administração. (...) Tais representantes dos preferencialistas terão, como parece intuitivo, os mesmos direitos, deveres e responsabilidades dos demais administradores (art. 153 e s. ) $^{173}$.

Desse modo, os titulares de ações preferenciais com essa vantagem realizarão a eleição dos administradores, em assembleia especial, por meio de votação em separado, sendo o seu resultado comunicado à companhia, a qual "não poderá recursar ou impugnar o resultado da eleição, salvo nos casos de não verificação dos requisitos legais" ${ }^{74}$.

Além disso, o parágrafo único do artigo 18 da Lei $n^{0}$ 6.404/76 enuncia que o estatuto social poderá subordinar as alterações estatutárias que vier a especificar, à aprovação, em assembleia especial, dos titulares de uma ou mais classes de ações preferenciais. Ou seja, o estatuto social poderá definir que determinadas alterações estatutárias somente poderão ser aprovadas mediante aprovação, em assembleia especial, de acionistas preferenciais, os quais poderão, desse modo, vetar determinadas alterações estatutárias. Nesse sentido, enuncia Carvalhosa:

"O direito de veto assegurado estatutariamente às preferenciais não pode abranger todas as alterações estatutárias, sob pena de não restar à assembleia geral nenhum poder constitutivo na companhia. Apenas alguns assuntos claramente determinados poderão ser objeto dessa audiência dos titulares de ações preferenciais" ${ }^{\prime 75}$.

Convém destacar que as vantagens políticas mencionadas acima poderão ser conferidas às ações preferenciais emitidas tanto por companhias fechadas, quanto pelas abertas" ${ }^{76}$.

\footnotetext{
${ }^{73}$ LUCENA, José Waldecy. Op. Cit., pág. 296.

${ }^{74}$ Ibid., pág. 296.

${ }^{75}$ CARVALHOSA, Modesto. Op. Cit., pág. 233.

${ }^{76}$ EIZIRIK, Nelson. Op. Cit., pág. 176.
} 


\subsection{Das Restrições a Direitos}

De acordo com o enunciado no artigo 111 da Lei $\mathrm{n}^{0} 6.404 / 76$, o estatuto poderá deixar de conferir às ações preferenciais, algum ou alguns dos direitos reconhecidos às ações ordinárias, inclusive o de voto, ou conferi-lo com restrições. Assim, verifica-se que as ações preferenciais podem sofrer restrições relativas ao exercício do direito de voto, mas também, a outros direitos, observado o disposto no artigo 109 da Lei ${ }^{\circ}$ $6.404 / 76$, o qual versa sobre os direitos essenciais dos acionistas.

Nesse sentido, em relação às ações preferenciais, o estatuto social da companhia poderá (i) conferir o exercício limitado do direito de voto, ou seja, restringi-lo a determinadas matérias e/ou circunstâncias; ou (ii) excluir o exercício do direito de voto.

No que tange aos demais direitos dos acionistas, conforme dispõe o artigo 109 da Lei 6.404/76, nem o estatuto social, nem a assembleia geral poderão privar o acionistas de: (i) participar dos lucros sociais; (ii) participar do acervo líquido da companhia, no caso de liquidação; (iii) fiscalizar, na forma prevista em lei, a gestão dos negócios sociais; (iv) exercer o direito de preferência para subscrição de ações, partes beneficiárias conversíveis em ações, debêntures conversíveis em ações e bônus de subscrição; ou (v) retirar-se da sociedade nos casos previstos em lei.

Convém destacar que o $\S 5^{\circ}$ do artigo 17 da Lei $n^{\circ}$ 6.404/76 prevê ainda que, salvo no caso de ações com dividendo fixo, o estatuto não pode excluir ou restringir o direito das ações preferenciais de participar dos aumentos de capital decorrentes da capitalização de reservas ou lucros. 
Como esclarece Carvalhosa, "o estatuto poderá restringir ou suprimir o direito de participar do aumento de capital mediante a capitalização de reservas de lucro, em relação aos acionistas preferenciais com dividendo fixo, de modo que estes acionistas sofrerão diluição justificada de suas respectivas participações, em razão do aumento de capital decorrente da capitalização das reservas" ${ }^{77}$. Por fim, tendo em vista que a Lei $n^{\circ}$ 6.404/76 não permite a atribuição de dividendo fixo às ações preferenciais admitidas à negociação no mercado de valores mobiliários, a restrição ou supressão acima referida não se estende a tais ações preferenciais.

Por meio de uma leitura do enunciado do artigo 111 da Lei $\mathrm{n}^{\mathrm{o}}$ 6.404/76, verifica-se que não há discriminação de quais outros direitos podem ser restringidos, que não o direito de voto. Em vista disso, Carvalhosa defende que:

"Diz a lei de 1976 (art. 111) que outros direitos outorgados às ações ordinárias também podem ser negados às ações preferenciais, desde que observados os direitos essenciais assegurados a todas as ações (art. 109) (...) na realidade, apenas o direito de voto pode ser objeto de restrição ou supressão. Todos os demais direitos pessoais e patrimoniais outorgados às ordinárias não podem ser negados aos titulares das ações preferenciais, por esbarrar, inclusive, no preceito contido no art. $109^{, 78}$.

Já Lucena adota um posicionamento intermediário, de modo que não veda a restrição de outros direitos, porém, não concebe quais outros direitos poderiam ser restringidos:

"A nós nos parece realmente difícil a criação estatutária - já que os direitos intangiveis e os próprios das ações preferenciais não podem ser suprimidos - de um direito especial, outorgado às ações ordinárias e que possa ser vedado às ações preferenciais ${ }^{, 79}$.

Por fim, Eizirik enuncia que

\footnotetext{
${ }^{77}$ CARVALHOSA, Modesto. Op. Cit., pág. 208.

${ }^{78}$ Ibid., pág. 222.

${ }^{79}$ LUCENA, José Waldecy. Op. Cit., pág. 1036.
} 
“(...) as restrições estatutárias podem versar não apenas sobre o direito de voto, mas também sobre outros direito assegurados às ações ordinárias, desde que não alcancem quaisquer daqueles considerados essenciais pelo artigo 109. Pode o estatuto social, por exemplo, conferir às ações ordinárias, ou a uma classe delas, se a companhia for fechada, o direito de seu titular resgatá-las, sem que idêntico direito seja estendido aos titulares de ações preferenciais. Podem também ser emitida ação ordinária com previsão de amortização, sem que os titulares de ações preferenciais tenham o mesmo direito" "80.

\subsection{Das Ações Preferenciais sem Direito a Voto ou com Restrições Negociadas no Mercado de Valores Mobiliários}

Em que pese o acerto do legislador em incorporar o instituto jurídico das ações preferenciais, infelizmente, a prática mostrou que eventuais abusos cometidos por acionistas controladores poderiam ocorrer e desvirtuar a sua finalidade. Tais abusos consistiram na emissão de ações preferenciais sem direito ao exercício de voto, com a única vantagem de prioridade no reembolso de capital.

Assim sendo, tais acionistas preferenciais não teriam direito de voto e, na prática, nenhuma vantagem patrimonial que justificasse a exclusão do direito de voto. Desse modo, "intensificaram-se os debates sobre a necessidade de fortalecimento do regime legal das ações preferenciais ${ }^{81 "}$ ao longo do final da década de 90 , os quais culminaram na reforma perpetrada pela Lei $\mathrm{n}^{\circ} 10.303 / 01$.

Convém destacar que a Lei ${ }^{\circ}$ 9.457/97 tentou reverter tais abusos, ao estabelecer que as ações preferenciais sem prioridade de dividendo fixo ou mínimo deveriam ter o direito ao recebimento de dividendo de, no mínimo, $10 \%$ superior ao distribuído às ações ordinárias, o que se aplicaria tanto para companhias fechadas como para as abertas.

\footnotetext{
${ }^{80}$ EIZIRIK, Nelson. Op. Cit., pág. 629.

${ }^{81}$ FRAGOSO, Daniela Neves Reali. AKKERMAN, Gustavo. Op. Cit., pág. 280.
} 
Já no que tange à Lei $\mathrm{n}^{\mathrm{o}} 10.303 / 01$, foram mantidas as vantagens e preferências estabelecidas pela Lei $n^{\circ}$ 9.457/97, mas também foi inserido o $\S 1^{\circ}$ ao artigo 17 da Lei $n^{\circ} 6.404 / 76$, o qual prevê vantagens mínimas que devem ser observadas para que as companhias abertas tenham suas ações preferenciais, sem direito de voto ou com restrições, admitidas à negociação no mercado de valores mobiliários. Como enuncia Eizirik:

\begin{abstract}
"A distinção feita pela Lei $n^{\circ}$ 10.303/2001 foi entre as ações preferenciais negociadas no mercado de valores mobiliários e as ações preferenciais que não são negociadas nesse mercado, não entre as ações preferenciais de companhia aberta e fechada. No caso de uma companhia ser aberta apenas em razão de emissão pública de debêntures, por exemplo, não será obrigatória a observância dos privilégios mínimos para as ações preferenciais sem voto, pois não são negociadas no mercado de valores mobiliários" ${ }^{, 82}$.
\end{abstract}

Nos termos do $\S 1^{\circ}$ do artigo 17 da Lei $n^{\circ} \quad 6.406 / 76$, independentemente do direito de receber, ou não, o valor de reembolso do capital, as ações preferenciais, sem direito de voto ou com restrição ao exercício deste direito, somente serão admitidas à negociação no mercado de valores mobiliários se a elas for atribuída, pelo menos, uma das seguintes preferências ou vantagens: (i) prioridade no recebimento de dividendo de, no mínimo, 3\% do valor patrimonial líquido da ação, no tocante a, no mínimo $25 \%$ do lucro líquido apurado no exercício; (ii) direito ao recebimento de dividendo de, no mínimo, 10\% superior ao distribuído às ações ordinárias; ou (iii) direito de serem incluídas na oferta pública de alienação de controle, sendo assegurado o recebimento de dividendos em igualdade de condições com as ações ordinárias.

Destaca-se que tais vantagens ou preferências podem, inclusive, ser atribuídas às ações preferenciais emitidas por companhias fechadas, sem qualquer restrição, pois o mencionado dispositivo legal visa proteger os investidores, estabelecendo vantagens ou preferências mínimas.

82 EIZIRIK, Nelson. Op. Cit., págs. 162 e 163. 
"As preferências enunciadas nas alíneas " $a$ " e " $b$ " do inciso I do $§ 1^{\mathrm{o}}$ são cumulativas, ou seja, o acionista preferencial terá prioridade no recebimento de ao menos 3\% sobre o valor do patrimônio líquido da ação e o direito de participar dos lucros eventualmente remanescentes em igualdade de condições com os acionistas ordinários, depois de assegurado o dividendo igual ao mínimo, não havendo, portanto, dividendo fixo" ${ }^{\text {"83 }}$.

Por fim, ressalta-se que as "vantagens previstas no $\S 1^{\circ}$ do artigo 17 da Lei $n^{\circ}$ 6.404/76 são cumuláveis às vantagens previstas nos incisos I e III ou II e III, todos do artigo 17 da Lei $\mathrm{n}^{\circ}$ 6.404/76, não sendo, contudo, cumuláveis às alternativas previstas nos incisos I e II, por serem incompatíveis a distribuição de dividendos em igualdade de condições com as ações ordinárias, (como determina o inciso I do artigo 17) e a distribuição de dividendos, no mínimo, $10 \%$ maiores do que os conferidos às ações ordinárias (prevista no inciso II desse mesmo dispositivo)" ${ }^{\text {84 }}$.

\footnotetext{
${ }^{83}$ Ibid., pág. 164.

${ }^{84}$ CARVALHOSA, Modesto. Op. Cit., págs. 304 e 305.
} 


\section{Considerações Específicas sobre as Ações Preferenciais sem Direito a Voto ou com Restrições}

\subsection{Do Direito de Voto e sua Função Econômica}

Ao convergirem suas vontades para a constituição da companhia, os seus acionistas elaboram o estatuto social, o qual consiste em um contrato por meio do qual são estabelecidos os direitos e as regras que irão nortear a consecução do objeto social e a organização interna da companhia.

Entretanto, é impossível prever no estatuto social todos os eventos futuros $\mathrm{e}$ as condutas que devem ser tomadas pelos acionistas, administradores e/ou a própria companhia.

Desse modo, o direito de voto confere ao acionista a possibilidade de manifestar sua vontade, em assembleia geral, em relação aos aspectos não previstos no estatuto social e/ou àqueles que, mesmo previstos, demandem a deliberação dos acionistas. Nesse sentido, esclarece Gorga que "o direito de voto representa o direito de tomada de decisões nos aspectos "incompletos" do contrato social, sendo o vocábulo incompleto utilizado no sentido empregado na literatura econômica, os quais constituem contratos que não preveem a conduta a ser tomada em relação a determinados eventos futuros possíveis" ${ }^{\prime 85}$.

Como bem observa Rego, "o direito de voto não consta no artigo 109 da Lei $n^{\circ}$ 6.404/76 com um dos "direitos essenciais" do acionista, mas tem especial significado por conferir o poder jurídico de participar na formação da vontade social" ${ }^{86}$.

\footnotetext{
${ }^{85}$ GORGA, Érica. Op. Cit., pág. 141.

${ }^{86}$ REGO, Marcelo Lamy. In Direito das Companhias. Alfredo Lamy Filho e José Luiz Bulhões de Pedreira (Coord.). Rio de Janeiro: Forense, 2009, vol.1, pág. 377.
} 
Conforme já exposto acima, a companhia poderá emitir ações preferenciais sem direito de voto ou com restrições, desde que o seu estatuto social declare as vantagens ou preferências atribuídas a cada classe dessas ações e as restrições a que ficarão sujeitas, nos termos do artigo 19 da Lei $n^{0} 6.404 / 76$.

Assim sendo, o direito de voto, apesar da sua relevante função econômica e jurídica, não constitui um direito essencial ao acionista, ou seja, um direito inalienável e intangível, tendo em vista que a lei prevê hipóteses de sua exclusão ou restrição.

O direito de voto é conferido aos acionistas em razão deles terem contribuído para a formação do capital social da companhia e, assim, por serem titulares da pretensão residual do seu resultado econômico, pois "os investidores que contribuem para o capital social são pagos por último, após os credores e empregados, de modo que eles somente terão direito ao montante residual" ${ }^{87}$.

Por conseguinte, dependendo do resultado econômico apurado pela companhia, os acionistas deverão suportar os prejuízos ou receberem os lucros auferidos, tendo em vista que são titulares do direito essencial de participação dos lucros sociais, nos termos do artigo 109 da Lei nº 6.404/76.

Nesse sentido, esclarecem Easterbrook e Fischel que:

"(...) como titulares de direitos residuais, os acionistas têm os incentivos apropriados (...) para tomar decisões discricionárias. A companhia deve investir em novos produtos, fatores de produção, e assim por diante, até que os ganhos e custos sejam idênticos na margem. Com exceção dos acionistas, faltam a todos os outros atores, os incentivos apropriados. (...) Os acionistas recebem a maioria dos ganhos marginais e incorrem na maioria dos custos marginais. Portanto,

\footnotetext{
${ }^{87}$ EASTERBROOK, Frank H.; FISCHEL, Daniel R. The economic structure of corporate law. Cambridge: Harvard University Press, 1991, pág 11.
} 
eles têm os incentivos adequados para exercer o direito de decidir exatamente o que deve ser feito em uma situação particular ${ }^{\prime 88}$.

Assim sendo, verifica-se que o direito de voto desempenha a função econômica de possibilitar aos acionistas, em última instância, a orientação da consecução do objeto social, de modo a maximizar o lucro a ser auferido pela companhia e, consequentemente, a ser atribuído aos acionistas, pois se exercerem o direito de voto de modo apropriado, receberão lucros e, se votarem de modo equivocado, arcarão com os prejuízos ${ }^{89}$.

E quais seriam os incentivos dos acionistas titulares de ações preferenciais sem direito de voto ou com restrições? Muitos investidores não têm interesse e/ou o conhecimento e qualificação necessários para interferirem na gestão da companhia.

Assim, tais investidores são motivados a investir seus recursos, por meio de subscrição de ações preferenciais sem direito de voto ou com restrições, com a intenção de obter as vantagens e preferências descritas no Capítulo 3 do presente trabalho, deixando os acionistas com a expertise e o interesse necessários à consecução do objeto social e da gestão da companhia tomarem as decisões através do exercício do voto. Nesse sentido, esclarecem Bulhões e Lamy que "em troca do voto [que talvez nunca seja exercido], o investidor recebe o título [ação preferencial] que lhe assegura dividendos, mesmo quando o lucro não basta para pagar os acionistas ordinários, tratando-se, na realidade de verdadeiras "ações de poupança'm! 90

Como bem esclarece Wald, "o privilégio econômico dado à ação preferencial não deixa de ser uma forma de compensação pela restrição

\footnotetext{
${ }^{88}$ Ibid., pág. 68.

${ }^{89}$ Ibid., pág. 68.

${ }^{90}$ WALD, Arnoldo. Em Defesa das Ações Preferenciais. Apud. LAMY, Alfredo; PEDREIRA, José Luiz Bulhões.
} 
política que sofre, ou seja, pelo fato de não participar do poder político, representado pelo controle da empresa"91.

A desigualdade de tratamento, estabelecida pela Lei $\mathrm{n}^{\circ}$ 6.404/76 aos acionistas titulares de ações preferenciais, decorre dos interesses distintos que tais acionistas possuem em relação à ingerência na companhia, os quais abrem mão do pleno exercício do direito de voto, para receberem em contrapartida, vantagens e preferências suficientes para justificarem seus investimentos. Como bem esclarece Wald:

\begin{abstract}
"Efetivamente, ao acionista preferencial normalmente só interessa a remuneração do capital investido, ou seja, o dividendo pago pela empresa, que, para ele, em termos puramente econômicos, equivale aos juros de um financiamento, embora tendo caráter aleatório, tanto em relação à sua existência, como ao seu valor, ambos dependentes do lucro realizado pela empresa. Aproximam-se das diversas formas de financiamento participativo, no qual o investidor participa dos riscos e dos lucros de empreendimento" ${ }^{\prime 92}$.
\end{abstract}

Portanto, ao passo que a função econômica do direito de voto reside, em última instância, em exercê-lo de modo a maximizar os lucros a serem auferidos pela companhia e, consequentemente, a ser atribuído a todos os acionistas; a decisão de suprimir ou restringir o seu exercício, têm como função econômica garantir que os acionistas interessados e/ou qualificados orientem as atividades e a gestão da companhia, pois estes terão maior probabilidade de auferirem resultados econômicos superiores. E, "em troca do voto que muitas vezes não seria efetivamente utilizado, o acionista investidor recebe o título que lhe assegura (i) dividendos acima dos dividendos pagos aos acionistas que têm direito de voto; ou (ii) dividendos assegurados, mesmo quando o lucro não for suficiente para o pagamento aos acionistas titulares de ações ordinárias" ${ }^{93}$.

\footnotetext{
${ }^{91}$ WALD, Op. Cit., pág. 19.

${ }^{92}$ Ibid., pág. 20.

${ }^{93}$ FRAGOSO, Daniela Neves Reali. AKKERMAN, Gustavo. Op. Cit., pág. 279 e 280.
} 


\subsection{Da Evolução Histórica da Discussão sobre o Princípio Uma Ação Um Voto}

Antes da promulgação da Lei $\mathrm{n}^{\mathrm{o}}$ 6.404/76, diversos debates nortearam o projeto de lei que a originou, especialmente, no tocante à manutenção da emissão de ações preferenciais sem direito de voto ou com restrições, bem como à elevação do limite de emissão de tais ações, fixado em $50 \%$ pelo Decreto-lei $2.627 / 40$, vigente à época, para $2 / 3$ do total de ações emitidas pela companhia.

Nesse sentido, a Bolsa de Valores do Rio de Janeiro emitiu seu parecer contrariamente aos dispositivos do referido projeto de lei que estabeleciam a possibilidade de emissão de ações preferenciais sem direito de voto ou com restrições e a elevação do limite de emissão de tais ações, conforme os principais trechos abaixo:

"(...) O projeto, ora em exame na cúpula do executivo, encerra em seu bojo um gravíssimo erro instrumental que, caso não seja corrigido, pode no futuro vir a constituir-se em verdadeiro "cavalo de troia" da iniciativa privada no Brasil. (...) Trata-se da manifestação, e não apenas isto, da ampliação do uso de "Ações Preferenciais de Participação Integral" como principal ferramenta de capitação de recursos próprios para a empresa nacional. O conhecimento público das consequências desta prática, de complexo e nocivo teor econômico e sobretudo social, não podia correr o risco de se ver perdido em algum escaninho burocrático ou engavetar-se em mesas comprometidas com as ideias expostas no anteprojeto nacional. É mister e inclusive obrigação de ordem moral e funcional desta Bolsa de Valores, fazer com que o País, o Senhor Presidente da República, o governo, as classes empresárias e o público em geral, tomem conhecimento de que esta nuance do sistema proposto no anteprojeto criará distorções, as mais graves como podem ser: democratizar o capital, mas não a propriedade; cristalizar definitivamente a propriedade empresarial no Pais; limitar a liquidez do empresário-controlador, tornando-se fator de desnacionalização; inibir o surgimento de administração profissional; reduzir a capacidade de crescimento em escala das empresas, agravando o processo de endividamento; diferenciar, afastando, portanto, o empresário-controlador de seus sócios-acionistas; constituir-se por todos estes fatores em elemento de grave desequilibrio social e econômico. (...) A ação preferencial é instrumento de captação de recursos de uso pouquíssimo difundido no exterior. Constituem-se praticamente em titulos de divida e conseguem exercer algum atrativo sobre os valores principalmente institucionais, em economias não sujeitas a taxa muito elevadas de inflação; por conterem seus dividendos algumas frações de pontos percentuais a mais do que aquelas das ações ordinárias ou juros de renda fixa. (...) Os defensores da existência e ampliação do uso de ações preferenciais de participação integral 
têm no mais das vezes imputado ao investidor e à pseudo predileção deste por um dividendo fixo, a popularização deste instrumento no País. (...) Na grande maioria, senão na quase totalidade das empresas registradas em Bolsa cujo capital está dividido em ações ordinárias e preferenciais, os dividendos pagos a ambas as classes de ações são via de regra idênticos. Quando notamos que as ações preferenciais possuem quase sempre uma valorização sobre as ordinárias entendemos que realmente não é o dividendo fixo a que aquelas tem direito que produz tal valorização, mas a liquidez e a maior negociabilidade das preferenciais sobre as ordinárias. (...) Na medida em que existem em iguais quantidades os dois tipos de ações, as que mais circulam são claramente aquelas que não se congelam em mãos do grupo controlador, e que portanto possuem uma maior aceitação pelo público. (...) Parece-nos só existir um caminho, a extirpação desse câncer denominado "ação preferencial de participação integral" ${ }^{\prime 4}$.

Em resposta ao parecer da Bolsa de Valores do Rio de Janeiro, Bulhões e Lamy, autores do anteprojeto da Lei 6.404/76, manifestaram seus entendimentos ressaltando as condições do mercado de valores brasileiro e defendendo a possibilidade de emissão de ações preferenciais sem direito de voto ou com restrições, bem como o aumento do limite de sua emissão, de acordo com os seguintes principais trechos:

\begin{abstract}
"O sucesso da sociedade anônima, como principal mecanismo institucional da economia capitalista, de livre iniciativa, resultou em grande parte da sua característica de modelo jurídico de organização em que as três subfunções empresariais são bem definidas, facilitando seu exercício por pessoas diferentes. O empresário-empreendedor é fundador ou acionista controlador, e em geral exerce um dos cargos da administração. Mas esses cargos podem também ser exercidos por administradores profissionais, que não participaram da criação da empresa nem são aplicadores de capital de risco. A função de investidor, graças à divisão do capital social em ações, pode ser exercida, simultaneamente, pelo empresário-empreendedor e por milhares ou milhões de investidores do mercado. Dai a flexibilidade do modelo, que serve para organizar desde a pequena empresa até as macroempresas dos países industrializados. (...) Os investidores de mercado querem aplicar capital e receber dividendos ou revender sua ação com lucro. Não se interessam por participar da administração da companhia nem - muito menos - admitem preocupar-se com seus problemas técnicos e de mercado, ou seus planos de expansão. Esperam que o acionista controlador e os administradores resolvam essas questões com a maior eficiência, mantenham a companhia próspera e respeitem seus direitos. Se isso não ocorrer, alienam as suas ações, investem em outras companhias ou se retiram do mercado. Em geral, não tem tempo nem capacidade técnica para ver todos os problemas da empresa ou das várias empresas em que investiram. Exercem profissões ou têm outros negócios e aplicam em ações, como em qualquer outro tipo alternativo de investimento, para obter renda ou lucro, desde
\end{abstract}

\footnotetext{
94 Observações sobre o Anteprojeto da Lei das Sociedades Anônimas. Jornal do Brasil, págs. 36 e 37, 21 de mar. de 1976,
} 
que não tenham que administrar os empreendimentos que geram esse lucro. (...) Extrapolaram para a sociedade anônima os princípios políticos do sufrágio universal e da igualdade de todos perante a lei - que nada tem a ver com o voto do acionista e os direitos e garantias que lhe devem ser assegurados. (...) Essas propostas (...) foram recusadas ou derrotadas pela realidade do mercado. Porque pretendiam negar o fato notório de que em toda a companhia aberta há duas espécies irredutiveis de acionistas: (a) o empresário-empreendedor, que cria e expande a empresa, a ela se dedica permanentemente e profissionalmente, vive todos os seus problemas, e se realiza nessa atividade; $e$ (b) o investidor de mercado, que objetiva, tão somente, a mera aplicação de capital" ${ }^{95}$.

Em que pese a manifestação da Bolsa de Valores do Rio de Janeiro, o anteprojeto foi convertido na Lei $\mathrm{n}^{\mathrm{o}} 6.404 / 76$, a qual continuou a prever o instituto das ações preferenciais sem direito de voto ou com restrições, sendo, inclusive, muito utilizadas por diversas companhias, até hoje, na capitação de recursos de investidores.

Entretanto, mesmo com o sucesso das ações preferenciais, até hoje parte da doutrina defende a sua extinção, tendo em vista os abusos cometidos por acionistas controladores e as reformas realizadas, especialmente no tocante à Lei $\mathrm{n}^{\mathrm{o}} 10.303 / 01$, a qual, para os defensores da extinção das ações preferenciais, não estabeleceram garantias suficientes para evitar que eventuais abusos possam ser cometidos por acionistas controladores.

Ademais, o descontentamento em relação à reforma perpetrada pela Lei $n^{\circ} 10.303 / 01$, conforme exposto acima, bem como a perpetuação da corrente doutrinária que defende a conferência do sufrágio universal às ações emitidas pelas companhias, culminaram na criação do Novo Mercado da BM\&FBovespa, o qual consiste em "uma seção destinada à negociação de ações de companhias que adotam, voluntariamente, práticas de governança corporativa adicionais às que são exigidas pela legislação

\footnotetext{
${ }^{95}$ LAMY, Alfredo; PEDREIRA, José Luiz Bulhões. Função Empresarial e Ações Preferenciais. Jornal do Brasil, 28 de março, 03 e 04 de abril de 1976.
} 
brasileira, inclusive a regra de só poderem emitir ações com direito de voto"$^{196}$. Sobre o Novo Mercado, Fragoso e Akkerman esclarecem que:

"A crença de muitos de que as ações preferenciais sem direito de voto deveriam ser expurgadas da lei brasileira (muitas vezes alicerçadas em fundamentos teóricos pobres, como a "democratização do capital" ou a "igualdade entre as ações"), o fracasso de seguidas reformas legais em construir um regime que garanta a existência de vantagens efetivas (...) entre outros fatores, acabaram por encontrar resposta num segmento de listagem, fruto da autorregulação dos entes privados, que não admite a negociação de ações preferenciais, prevalecendo a regra "uma ação um voto" ${ }^{\prime \prime 7}$.

Em que pese a sua contribuição para o desenvolvimento do mercado de capitais brasileiros, o Novo Mercado não deve ser encarado como o uma meta a ser atingida, mas sim, como mais uma alternativa para o público investidor e as companhias emissoras alinharem seus interesses (este tema será aprofundado no Capítulo 5 do presente trabalho).

\subsection{Da Distribuição de Dividendos}

A expressão dividendo "deriva do latim dividendus (que deve ser dividido), consistindo na percentagem ou rendimento que cabe aos sócios ou acionistas de uma sociedade, conforme o caso, auferido proporcionalmente à participação que detêm na respectiva sociedade"198.

A finalidade precípua da companhia é auferir lucros na consecução se seu objeto social e, de acordo com a sistemática adotada por nosso ordenamento jurídico, uma vez apurado o lucro, este deve ser distribuído aos acionistas, em conformidade com o disposto na lei e no estatuto social.

\footnotetext{
96 Conceito extraído da página da BM\&FBovespa. Disponível em: $<$ http://www.bmfbovespa.com.br/ptbr/servicos/solucoes-para-empresas/segmentos-de-listagem/no vomercado.aspx?Idioma=pt-br>. Acessado em 06 mar. 2014.

${ }^{97}$ FRAGOSO, Daniela Neves Reali. AKKERMAN, Gustavo. Op. Cit., pág. 289.

${ }^{98}$ BRUSCHI, Gilberto Gomes. Dividendos Das Ações Preferenciais na Lei 10.303/2001. Revista de Direito Privado, 2003, vol. 16, pág. 115.
} 
Nos termos do I do artigo 109 da Lei $\mathrm{n}^{\circ}$ 6.404/76, nem o estatuto social nem a assembleia geral poderão privar o acionista do direito de participar dos lucros sociais, sendo, portanto, um direito essencial. Nesse sentido, Leães concebe "o direito do acionista ao lucro social como um direito subjetivo e inerente à qualidade do sócio, e do qual não pode ser despojado pela sociedade, por ser desprovida de legitimação para tanto" 99 .

Mesmo que a lei garanta a distribuição do dividendo, a sua percepção pelos acionistas fica condicionada à apuração de lucro pela companhia, pois o princípio da intangibilidade do capital social, conforme já exposto, veda a distribuição de lucro em prejuízo ao capital. Bruschi destaca que "o direito de participar dos lucros é intangível ao acionista, o qual não perece ante a ausência de lucratividade, pois tal direito é conferido a todos os acionistas, mas a percepção do lucro, não" ${ }^{100}$. Contudo, como bem observa Gorga:

"(...) apesar de o direito proclamar tal participação do acionista nos lucros societários, na prática econômica a distribuição de dividendos é controversa porque a companhia enfrenta uma dicotomia entre a decisão de reter lucros para expandir seus negócios, através de autofinanciamento, ou de distribui-los aos acionistas $^{\prime \prime 101}$.

Nos termos do II do artigo 132 da Lei $n^{0}$ 6.404/76, compete à assembleia geral ordinária deliberar sobre a destinação do lucro líquido do exercício e a distribuição de dividendos. Desse modo, verifica-se que apenas os acionistas detentores de ações com direito de voto irão deliberar sobre a destinação do lucro líquido apurado e a distribuição de dividendos.

Por acreditar que a retenção de dividendos configura prejuízo aos acionistas minoritários e, assim, visando coibir que acionistas controladores

\footnotetext{
${ }^{99}$ LEÃES, Luis Gastão Paes de Barros. Do Direito do Acionista ao Dividendo. São Paulo: Obelisco, 1969, p. 305.

${ }^{100}$ BRUSCHI, Gilberto Gomes. Op. Cit., pág. 115.

${ }^{101}$ GORGA, Érica. Op. Cit., pág. 160.
} 
deliberassem por reter integralmente todo o lucro apurado pela companhia, o legislador optou por estabelecer o dividendo obrigatório, a ser apurado conforme o disposto no artigo 202 da Lei $n^{\circ}$ 6.404/76, o qual dispõe:

"Art. 202. Os acionistas têm direito de receber como dividendo obrigatório, em cada exercício, a parcela dos lucros estabelecida no estatuto ou, se este for omisso, a importância determinada de acordo com as seguintes normas:

I - metade do lucro líquido do exercício diminuído ou acrescido dos seguintes valores:

a) importância destinada à constituição da reserva legal (art. 193); e

b) importância destinada à formação da reserva para contingências (art. 195) e reversão da mesma reserva formada em exercícios anteriores;

II - o pagamento do dividendo determinado nos termos do inciso I poderá ser limitado ao montante do lucro líquido do exercício que tiver sido realizado, desde que a diferença seja registrada como reserva de lucros a realizar (art. 197);

III - os lucros registrados na reserva de lucros a realizar, quando realizados e se não tiverem sido absorvidos por prejuizos em exercícios subseqüentes, deverão ser acrescidos ao primeiro dividendo declarado após a realização.

$\S 1^{\circ} \mathrm{O}$ estatuto poderá estabelecer o dividendo como porcentagem do lucro ou do capital social, ou fixar outros critérios para determiná-lo, desde que sejam regulados com precisão e minúcia e não sujeitem os acionistas minoritários ao arbitrio dos órgãos de administração ou da maioria.

$\S 2^{\circ}$ Quando o estatuto for omisso e a assembléia-geral deliberar alterá-lo para introduzir norma sobre a matéria, o dividendo obrigatório não poderá ser inferior a $25 \%$ (vinte e cinco por cento) do lucro líquido ajustado nos termos do inciso I deste artigo.

$\S 3^{\circ} \mathrm{A}$ assembléia-geral pode, desde que não haja oposição de qualquer acionista presente, deliberar a distribuição de dividendo inferior ao obrigatório, nos termos deste artigo, ou a retenção de todo o lucro líquido, nas seguintes sociedades:

I - companhias abertas exclusivamente para a captação de recursos por debêntures não conversíveis em ações;

II - companhias fechadas, exceto nas controladas por companhias abertas que não se enquadrem na condição prevista no inciso I.

$\S 4^{\circ} O$ dividendo previsto neste artigo não será obrigatório no exercício social em que os órgãos da administração informarem à assembléia-geral ordinária ser ele incompativel com a situação financeira da companhia. O conselho fiscal, se em funcionamento, deverá dar parecer sobre essa informação e, na companhia aberta, seus administradores encaminharão à Comissão de Valores Mobiliários, dentro de 5 (cinco) dias da realização da assembléia-geral, exposição justificativa da informação transmitida à assembléia.

$\S 5^{\circ}$ Os lucros que deixarem de ser distribuídos nos termos do $\S 4^{\circ}$ serão registrados como reserva especial e, se não absorvidos por prejuizos em exercícios subseqüentes, deverão ser pagos como dividendo assim que o permitir a situação financeira da companhia.

$\S 6^{\circ}$ Os lucros não destinados nos termos dos arts. 193 a 197 deverão ser distribuidos como dividendos". 
Nos Estados Unidos, por exemplo, não há previsão legal do dividendo obrigatório a ser distribuído aos acionistas, sendo competência dos administradores decidir sobre a distribuição e/ou retenção, bem como fixar qual será o montante a ser distribuído. De acordo com a decisão proferida pela Suprema Corte do Estado de Michigan no leading case Dodge vs. Ford Motors ${ }^{102}$, aos administradores é atribuído o poder discricionário em relação à distribuição ou retenção dos lucros, não havendo intervenção do judiciário, a menos em casos de fraude, abuso ou dolo.

Em que pese a previsão do dividendo obrigatório, convém destacar que os $\S \S 3^{\circ}$ e $4^{\circ}$ do artigo 202 da Lei $n^{\circ} 6.404 / 76$ preveem a possibilidade de distribuição inferior ao dividendo obrigatório ou a retenção de todo o lucro.

O $\S 3^{\circ}$ prevê que a assembleia geral de determinadas companhias poderá, desde que não haja voto contrário de nenhum acionista presente, deliberar a retenção integral do lucro apurado ou a distribuição de dividendos inferior ao fixado como obrigatório. Como enuncia Carvalhosa:

\begin{abstract}
"As alterações introduzidas neste $\$ 3^{\circ}$ pela Lei $n^{\circ} 10.303 / 01$, por uma lado, ampliaram e, por outro restringiram as espécies de companhias que estão autorizadas a, mediante deliberação assemblear, distribuir dividendo inferior ao obrigatório (...) além das companhias fechadas, também as companhias abertas que abriram seu capital exclusivamente para a captação de recursos por meio da emissão de debêntures não conversiveis em ações poderão reter arte ou todo o dividendo obrigatório (...) por outro lado, o inciso II deste $\S 3^{\circ}$ veda a distribuição de dividendos inferiores ao mínimo nas companhias fechadas controladas por companhias abertas cujas ações sejam negociadas no mercado" ${ }^{103}$.
\end{abstract}

Por seu turno, o $\$ 4^{\circ}$ estabelece que os órgãos da administração poderão informar à assembleia geral ordinária que o dividendo obrigatório é

\footnotetext{
${ }^{102}$ Dodge v. Ford Motor Co., 204 Mich. 459, 170 N.W. 688, 1919

${ }^{103}$ CARVALHOSA, Modesto. Op. Cit., pág. 946.
} 
incompatível com a situação financeira da companhia, de modo que a obrigatoriedade do pagamento poderá ser dispensada e os acionistas poderão deliberar por distribuição inferior ao dividendo obrigatório ou a retenção integral, do lucro conforme o caso. Nesse sentido, esclarece Piva:

\begin{abstract}
"(...) a capacidade da companhia para pagar dividendos em moeda depende do grau de liquidez do seu ativo e do montante e época de vencimento de suas obrigações. Ainda, portanto, que todo o lucro líquido do exercício tenha sido realizado em moeda, a situação financeira da companhia pode recomendar o diferimento do dividendo obrigatório. No reconhecimento de que a capacidade da companhia para pagar o dividendo obrigatório não depende apenas da parcela do lucro líquido do exercício realizada em dinheiro, a lei admite, além da formação da reserva de lucro, que os órgão da administração deixem de distribuir o dividendo obrigatório se o considerarem incompatível com a situação financeira da companhia"104.
\end{abstract}

A respeito do dividendo obrigatório, parte da doutrina sustenta que a previsão legal é insuficiente, como defende Lima:

\begin{abstract}
"A fixação estatutária de dividendo obrigatório, segundo os parâmetros legais, conduz a uma acomodação inquestionável nos niveis mais baixos. (...) A observação da realidade tem demonstrado que, a partir da vigência da lei, nenhuma companhia brasileira mantém omisso o seu estatuto, de modo a justificar um dividendo de, pelo menos, metade do lucro líquido ajustado e distribuivel. (...) Uma análise compreensiva e crítica dos textos legais e de seu reflexo na realidade evidencia, sem sombra de dúvida, que a proteção aos acionistas minoritários (não controladores), visada pelo instituto, não deixou de ser mera aspiração teórica, sem efeitos práticos positivos" ${ }^{105}$.
\end{abstract}

Porém, como destaca Gorga "a decisão de política legislativa sobre se deve a lei estabelecer padrões mínimos para a distribuição de dividendos não é fácil nem pacífica" ${ }^{106}$. Desse modo, não é possível afirmar de antemão que uma política de dividendos orientada para uma distribuição inferior ou inexistente sempre será prejudicial aos acionistas minoritários, sendo necessário, portanto, avaliar a compatibilização de interesses entre os acionistas e a companhia.

\footnotetext{
${ }^{104}$ PIVA, Luiz Carlos. In Direito das Companhias. Alfredo Lamy Filho e José Luiz Bulhões de Pedreira (Coord.). Rio de Janeiro: Forense, 2009, v.2, pág. 1719.

${ }^{105}$ LIMA, Oscar Brina C. O Acionista Minoritário no Direito Brasileiro. Rio de Janeiro: Forense, 1994, págs. 18-20 e 132.

${ }^{106}$ GORGA, Érica. Op. Cit., págs. 160 e 161.
} 
Pode ser interessante aos acionistas sacrificarem o seu direito à percepção de dividendos em prol da captação de baixo custo de recursos por parte da companhia, objetivando uma expansão dos negócios, ou fortalecimentos das reservas, entre outros. Nesse sentido, Graham explica que:

\begin{abstract}
"No passado, a política de dividendos foi objeto de controvérsias frequentes entre os acionistas individuais, ou minoritários, e os administradores [em referência ao mercado de valores mobiliários dos Estados Unidos]. Em geral, esses acionistas desejavam dividendos mais generosos, enquanto os administradores preferiam manter os lucros dentro do negócio "para fortalecer a companhia". Estes últimos pediam aos acionistas que sacrificassem seus lucros atuais para o bem da empresa e para seu próprio beneficio futuro no longo prazo. No entanto, nos últimos anos a atitude dos investidores para com os dividendos tem mudado de maneira gradual, porém significativa. $O$ argumento básico agora para pagar dividendos menores em vez de mais generosos não é que a companhia "precise" de dinheiro, mas ao contrário, que ela pode usá-lo em beneficio direto e imediato dos acionistas ao reter recursos para financiar a expansão lucrativa. (...) Hoje em dia, é muito provável que a empresa que deliberadamente mantém baixo seus pagamentos de dividendos, com a aprovação tanto de investidores quanto de especuladores, seja forte $e$ crescente $^{107}$.
\end{abstract}

Resumidamente, acionistas podem ter interesse em renunciar a percepção de dividendos ou receberem dividendos menores, objetivado a expansão dos negócios da companhia e, consequentemente, a valorização de suas ações no longo prazo. Esta estratégia é conhecida como reinvestimento lucrativo.

Corroborando este entendimento, Modigliani e Miller "enunciam que a política de distribuição de dividendos não interfere na geração de riqueza dos acionistas. Por meio de seu estudo (assentado sobre as premissas de perfeito fluxo de informações e custos nulos de transação - mercado perfeito), Modigliani e Miller demonstraram que se a companhia não distribuir os lucros aos acionistas, o valor do dividendo não distribuído é

\footnotetext{
${ }^{107}$ GRAHAM, Benjamin. O Investidor Inteligente. Rio de Janeiro: Nova Fronteira, 2007, $5^{\mathrm{a}}$ Edição, pág. 533.
} 
automaticamente refletido na cotação das ações emitidas, com a consequente valorização destas, sendo que caberá aos acionistas decidirem se vão auferir tal valor diretamente, por meio da alienação das respectivas ações ou, indiretamente, mantendo-as em seu portfólio" ${ }^{108}$.

Assim sendo, baixas distribuições ou retenção de dividendos tendem a ser tornarem cada vez mais interessantes para os investidores, quanto melhor for o histórico de crescimento e de valorização das ações de emissão da companhia. Por sua vez, isto não significa que os investidores sempre adotarão a estratégia de reinvestimento lucrativo, pelo contrário, a distribuição do dividendo pode ser mais atrativa, dependendo dos seus interesses. Como bem esclarece Graham:

\begin{abstract}
"A avaliação pelo mercado da política de dividendos em dinheiro parece marchar na seguinte direção: nos casos em que não se coloca a ênfase principal no crescimento, a ação é vista como uma "ação de receita", e a taxa de dividendos retém sua importância antiga como o determinante principal do preço de mercado. No outro extremo, as ações claramente reconhecidas como pertencentes à categoria de crescimento rápido são cotadas principalmente com base na taxa de crescimento esperada, digamos, da década seguinte, sendo a taxa de dividendo em dinheiro mais ou menos desconsiderada" ${ }^{\prime 109}$.
\end{abstract}

Apesar de representar uma tendência nos últimos anos, a estratégia de reinvestimento lucrativo não pode ser vislumbrada como uma regra, mas sim, como uma alternativa. Em muitos casos, não é possível classificar companhias de acordo com a ênfase de crescimento, pois se encontram em uma posição intermediária.

Desse modo, cabe a todos os acionistas verificarem se os lucros reinvestidos estão sendo bem utilizados pela administração e, consequentemente, gerando aumento satisfatório nos lucros auferidos pela companhia. Há de se convir que tal verificação é fácil de ser feita no que

\footnotetext{
${ }^{108}$ MILLER, Merton; MODIGLIANI, Franco. Dividend Policy, Growth and Valuation of Shares. Journal of Business, v. 34, pág. 411, out. 1961. Disponível em: <http://student.bus.olemiss.edu /files/fuller/div/Miller\%20and\%20Modigliani\%201961.pdf>. Acessado em 06 mai. 2014.

${ }^{109}$ GRAHAM, Benjamin. Op. Cit., pág. 535.
} 
tange às companhias de rápido crescimento, porém a recíproca não é verdadeira para aquelas que apresentam resultados medíocres, como explica Graham:

"(...) os dividendos são, por vezes mantidos em niveis baixos por companhias relativamente pouco prósperas com o propósito declarado de expandir o negócio. Acreditamos que tal política é patentemente ilógica e requer tanto uma explicação completa quanto uma defesa convincente antes de os acionistas aceitaram-na. Com base no histórico, não há razão a priori para acreditar que os donos se beneficiarão de movimentos de expansão, financiados com seu dinheiro, de um negócio que mostra resultados mediocres e mantém os administradores existentes ${ }^{\prime 110}$.

Como bem observa Gorga, em referência ao estudo da distribuição de dividendos, "esta é uma das áreas em que mesmo uma metodologia de estudo interdisciplinar parece não apresentar solução normativa totalmente satisfatória para o deslinde da questão (...)"111.

Pela leitura do artigo 202 da Lei $n^{\circ}$ 6.404/76, verifica-se que o legislador optou por não conferir, às companhias abertas com ações negociadas no mercado de valores mobiliários, a possibilidade de distribuir dividendos inferiores ao fixado como obrigatório ou realizar a retenção integral do lucro, se assim decidirem os acionistas presentes na assembleia geral (salvo a ressalva referente às condições financeiras da companhia, nos termos do $\S^{\circ}$ do mencionado dispositivo).

Portanto, conforme exposto acima, a escolha do legislador ignora eventual interesse dos acionistas de companhias abertas de realizarem a estratégia do reinvestimento lucrativo, filiando-se a teoria já ultrapassada de que somente a distribuição e percepção dos lucros são interessantes para os acionistas.

\footnotetext{
${ }^{110}$ Ibid., pág. 536.

${ }^{111}$ GORGA, Érica. Op. Cit., pág. 170.
} 


\subsection{Da Aquisição do Direito de Voto}

O fundamento da concepção das ações preferenciais reside na possibilidade de o acionista ter determinados direitos restringidos e, em troca, receber vantagens ou preferências patrimoniais e/ou políticas. Desse modo, o acionista preferencial com restrição ou exclusão do direito de voto, que tenha recebido preferências ou vantagens patrimoniais, não terá o seu interesse atendido se a companhia reter integralmente os lucros, tendo em vista que suas vantagens ou preferências patrimoniais serão inócuas neste caso.

As vantagens patrimoniais conferidas aos acionistas preferenciais com restrição ou exclusão do direito de voto também serão inócuas se a companhia for incapaz de auferir lucro a ser distribuído, ou seja, se a administração e os acionistas titulares do pleno exercício do direito de voto não desenvolverem adequadamente as atividades e a gestão da companhia.

O entendimento acima referido, consolidou-se em razão do fundamento da criação do instituto jurídico das ações preferenciais, o qual parte da premissa de que, nas palavras de Lamy, "se não existe vantagem patrimonial, não há como caracterizar a ação como preferencial; terá que ser considerada ordinária e terá direito de voto" ${ }^{112}$.

Nesse sentido, de modo a evitar que as preferências ou vantagens patrimoniais atribuídas aos acionistas preferenciais sejam inócuas, os $\S \S 1^{\circ}$ e $2^{\circ}$ do artigo 111 da Lei $n^{\circ} 6.404 / 76$ dispõem que as ações preferenciais (i) sem direito de voto adquirirão o exercício desse direito se a companhia, pelo prazo previsto no estatuto, não superior a três exercícios consecutivos,

${ }^{112}$ LAMY, Alfredo; PEDREIRA, José Luiz Bulhões. A Lei das S.A. Op. Cit., pág. 398. 
deixar de pagar os dividendos fixos ou mínimos a que fizerem jus; e (ii) com direito de voto restrito terão suspensas as limitações ao seu exercício.

Como esclarece Lucena, a intenção do legislador é "permitir que os acionistas que ficaram à margem do processo decisório e que não tiveram satisfeitos os direitos que lhes haviam sido prometidos, possam interferir na gestão da companhia para tentar recolocá-la no caminho da lucratividade $^{113}$. Nesse sentido, expõe Parente:

\begin{abstract}
"Efetivamente, seria iníquo para o acionista, que tem como contrapartida da exclusão de seu voto o recebimento de um dividendo privilegiado, assistir amordaçado o desenrolar da decadência da sociedade sem poder intervir. É irrazoável admitir-se que fique à frente da sociedade quem deu margem aos prejuizos, sob o risco de se atingir a total desvalorização do patrimônio social. Evidentemente não foi esse desígnio antidemocrático que movimentou o legislador. O espirito é permitir o exercício do poder de controle pelos acionistas prejudicados, ao menos, até que a sociedade retorne a seu rumo. (...) $O$ direito de participar dos lucros sociais tem caráter periódico (anual). Assim, a cada ano em que não se pagam os dividendos está se impedindo um direito essencial do acionista. A contrapartida para essa obstrução só pode ser o direito de voto para tentar sustar a infração continuada. (...) Assim, a única conclusão lídima acerca do pleito é de que todos os preferencialistas adquirem o direito de voto após a inadimplência contínua da companhia, em razão da própria natureza das ações preferenciais" ${ }^{114}$.
\end{abstract}

Desse modo, a lei confere ao acionista preferencial cujas vantagens ou preferências patrimoniais tenham se tornado inócuas, a possibilidade de intervir na gestão da companhia, por meio da aquisição do direito de voto ou suspensão das restrições em seu exercício, de modo que tal acionista tenha a possibilidade de "contribuir para a modificação do quadro administrativo da companhia e reverter a incapacidade ou impropriedade de sua administração, visando a percepção de lucros" ${ }^{115}$. Assim esclarece Carvalhosa:

\footnotetext{
${ }^{113}$ LUCENA, José Waldecy. Op. Cit., pág. 1038.

${ }^{114}$ PARENTE, Norma. Voto no âmbito do Processo Administrativo CVM RJ 2002/2941, em em 21 out. 2002.

${ }^{115}$ FERREIRA, Waldemar. Tratado de Sociedade Mercantis. Rio de Janeiro: Freitas Bastos 1958, vol. IV, pág. 1393.
} 
"A lei nova reitera os preceitos da anterior, fundada no mesmo princípio de que a restrição ao direito de voto somente poderá ser mantida se o acionista gozar efetivamente de vantagens patrimoniais, reveladas pelo efetivo pagamento de dividendos mínimo ou fixos, cumulativos ou não, instituídos no estatuto social (...) Por outro lado, estabelece a já referida suspensão da mora no pagamento de dividendos durante o período de implantação do empreendimento inicial da companhia. Essa suspensão deverá estar prevista no estatuto social e se referirá apenas ao empreendimento inicial da sociedade e não aos subseqüentes, decorrente dos planos de expansão da mesma"116.

A suspensão referente ao período de implantação do empreendimento inicial da companhia, a que Carvalhosa se refere, advém do $\S 3^{\circ}$ do artigo 202 da Lei $n^{\circ} 6.404 / 76$, o qual enuncia que o estatuto poderá estipular que a eventual aquisição do direito de voto ou a suspensão da limitação ao direito de voto das ações preferenciais, conforme o caso, apenas poderão ocorrer a partir do término da implantação do empreendimento inicial da companhia. Como expõe Eizirik:

“O $\S 3^{\circ}$, por sua vez, prevê uma possibilidade de grande relevância prática para projetos de maior vulto, que, por suas características, demandam investimentos cujo retorno não ocorrerá no curto prazo, tornando impossivel, pois, o pagamento de dividendos: a de dispor o estatuto que o prazo de 3 (três) anos somente passará a contar a partir do término da implantação do empreendimento inicial da companhia" $" 117$.

Contudo, "a Lei $\mathrm{n}^{\mathrm{o}}$ 6.404/76 disciplinou a situação inicial da companhia de forma muito simplista, pois não estipulou um prazo legal máximo de tolerância para a implantação do empreendimento" ${ }^{118}$. No entendimento de Lucena, "o estatuto deve expressamente indicar o prazo (número de exercícios) necessário à implantação do empreendimento, pois se for omisso ou se utilizar de expressões vagas, não haverá essas tolerância inicial" $" 119$. No mesmo sentido, Eizirik esclarece que

"É conveniente que o estatuto estabeleça, com razoável precisão, a data ou o exercício em que terminará a implantação do empreendimento inicial da

\footnotetext{
${ }^{116}$ CARVALHOSA, Modesto. Op. Cit., pág. 464.

${ }^{117}$ EIZIRIK, Nelson. Op. Cit., pág. 638.

${ }^{118}$ LUCENA, José Waldecy. Op. Cit., págs. 1041 e 1042.

${ }^{119}$ Ibid., pág. 1042.
} 
companhia, para que eventuais manobras protelatórias do acionista controlador e da administração da companhia não fraudem o disposto no $\$ 1^{\circ, 120}$.

Assim sendo, "tanto a doutrina quanto a jurisprudência são pacíficas no que tange à aplicação dos referidos dispositivos, independentemente da causa do não pagamento dos dividendos, por três exercícios sociais consecutivos" $^{121}$. Entretanto, convém destacar a controvérsia em relação à aplicação do enunciado dos $\S \S 1^{\circ}$ e $2^{\circ}$ do artigo 111 da Lei $n^{\circ} 6.404 / 76$, no que tange ao dividendo diferenciado e as outras vantagens que podem ser atribuídas às ações preferenciais.

Após a promulgação da Lei $n^{\circ}$ 9.457/97, que, conforme já mencionado, estabeleceu o instituto do dividendo diferenciado como uma das possíveis vantagens atribuídas às ações preferenciais com restrição ou sem direito de voto (art. 17, I da Lei $n^{0}$ 6.404/76), houve forte discussão doutrinária, em razão da referida lei não ter alterado a redação dos $\S \S 1^{\circ} 2^{\circ}$ do artigo 111 da Lei $n^{\circ}$ 6.404/76, de modo a incluir, expressamente, que as ações preferenciais com direito a dividendo diferenciado também poderiam adquirir ou teriam suspensa as restrições ao direito de voto, conforme o caso, na hipótese do não pagamento de dividendos em três exercícios sociais consecutivos por parte da companhia.

Em defesa da inaplicabilidade dos $\S \S 1^{\circ}$ e $2^{\circ}$ do artigo 111 da Lei $n^{\circ}$ 6.404/76 em relação ao inadimplemento da companhia em pagar o dividendo diferenciado, Fabio Ulhôa Coelho ${ }^{122}$, Luiz Leonardo Cantidiano $^{123}$, Paulo Cesar Aragão ${ }^{124}$ e Eizirik fundamentam seus

\footnotetext{
${ }^{120}$ EIZIRIK, Nelson. Op. Cit., págs. 638 e 639.

${ }^{121}$ WALD, Arnoldo. Do Direito de Voto dos Titulares de Ações Preferenciais Após o Decurso de Três Exercícios sem Pagamento de Dividendos. Revista dos Tribunais, 1988, vol. 634, pág. 8.

${ }^{122}$ COELHO, Fábio Ulhôa Coelho. Parecer nos autos da Ação Ordinária 951/2000 que tramitou perante a $1^{\text {a }}$ Vara Cível da Comarca de Mirassol, Estado de São Paulo.

${ }_{123}$ CANTIDIANO, Luiz Leonardo. Revista Abamec-RJ, Outubro de 1997.

${ }^{124}$ ARAGÃO, Paulo Cezar. In A Reforma da Lei das S.A. Jorge Lobo (Coord.). Rio de Janeiro: Atlas, 2003, 2 $2^{\text {a }}$ Edição, págs. 158 a 169.
} 
entendimentos, principalmente, na observância da literalidade da lei. Nesse sentido, Eizirik explica que:

"Como se depreende do texto legal, somente adquirem o direito de voto os titulares de ações preferenciais cujas vantagens patrimoniais consistam em prioridade no recebimento de dividendos fixos ou mínimos. Qualquer outra interpretação, estendendo tal medida protetiva às ações preferenciais sem dividendo fixo ou mínimo seria contra legem. De acordo com a boa hermenêtica jurídica, devem-se compreender as palavras da lei como tendo alguma eficácia (...), visto que, em princípio, não existem palavras inúteis no texto legal. (...) $O$ legislador especificou no $\$ 1^{\circ}$ apenas 2 (duas) dentre as diferentes modalidades de vantagens patrimoniais que a Lei das S.A. admitiu que sejam conferidas à ações preferenciais. Caso fosse intenção do legislador conferir a todas as ações preferenciais a possibilidade de adquirir o exercício desse direito teria ele mencionado expressamente qualquer vantagem, permitindo assim, ao intérprete legitimamente concluir que todas as modalidades de privilégios estariam ali incluidas ${ }^{, 125}$.

Em sentido contrário, em defesa da aplicabilidade, Parente, Lobo e

Wald fundamentam seus entendimentos na intenção do legislador ao prever

os $\S \S 1^{\circ}$ e $2^{\circ}$ do artigo 111 da Lei $n^{\circ} 6.404 / 76$, bem como na finalidade econômica deste dispositivos, conforme expõe Wald:

\begin{abstract}
"Coerente com a política legislativa subjacente ao art. 111 da Lei 6.404/76, cabe interpretar as suas disposições no sentido de que o acionista preferencial passará a ter direito de voto se não forem recebidos os dividendos, inclusive os fixos e mínimos estatutariamente assegurados, por periodo de tempo previsto no estatuto ou na lei. (...) Assim, com base na interpretação sistemática dos arts. 17 e 111, da Lei 6.404/76, bem como na investigação da ratio legis e da finalidade econômica das normas jurídicas em enfoque, concluímos que o art. 111 da Lei 6.404/76, e especialmente o art. 111, \$1 ${ }^{\circ}$, da Lei 6.404/76 se aplica a todas as hipóteses de acionistas preferenciais que deixarem de receber os dividendos por mais de três exercícios, qualquer que tenha sido a forma de preferência que lhe foi estatutariamente assegurada",126.
\end{abstract}

\title{
Da mesma forma, Lobo enuncia que:
}

"(...) as ações preferenciais de qualquer espécie e por conseguinte, as ações preferenciais com dividendo diferenciado, adquirem o exercício do direito de

\footnotetext{
${ }^{125}$ EIZIRIK, Nelson. Op. Cit., pág. 632.

${ }^{126}$ WALD, Arnoldo. Da Aquisição do Direito de Voto pelas Ações Preferenciais por Falta de Pagamento dos Dividendos Interpretação do Art. 111, e $\S 1^{\circ}$ da Lei 6.404/76. Revista de Direito Bancário e do mercado de Capitais, 2001, vol. 12, pág. 37.
} 
voto se a companhia deixar de pagar dividendos pelo prazo previsto no estatuto social, não superior a três exercícios consecutivos ${ }^{\prime \prime 27}$.

Em relação à jurisprudência, o posicionamento da Comissão de Valores Mobiliários ("CVM") sobre a questão foi inicialmente decidido no âmbito do Processo Administrativo CVM No RJ97/1297, no qual foi decidido que não há aquisição do direito de voto de por parte das ações preferenciais que não tenham como prioridade o recebimento de um dividendo fixo ou mínimo, ainda que possuam direito ao dividendo majorado de $10 \%$.

Posteriormente, a CVM foi instada a rever o entendimento firmado no âmbito do Processo Administrativo CVM No RJ97/1297, em razão da reforma da Lei $\mathrm{n}^{\mathrm{o}}$ 10.303/01. Nesse sentido, Campos decidiu que "(...) o entendimento do Colegiado da CVM apresentado no Processo CVM $n^{\circ}$ 97/1297, está rigorosamente correto à luz do direito positivo brasileiro, inclusive após a edição da Lei $n^{o}$ 10.303/01, não merecendo qualquer reparo $(. . .)^{\prime \prime 128}$.

Por fim, a CVM consolidou o entendimento exposto acima, conforme decisão de Trindade no âmbito do Processo Administrativo CVM $\mathrm{N}^{\mathrm{o}} \mathrm{RJ} 2005 / 7329$, ao proferir seu voto no "(...) sentido de que somente às ações preferenciais às quais tenha sido concedido direito ao recebimento de dividendos fixos ou mínimos seja aplicável a regra do art. $111, \S 1^{\circ}$, da Lei $6.404 / 76^{1129}$.

Em relação à discussão abordada no item 4.3 acima, cabe indagar se a estratégia de reinvestimento lucrativo poderia ser interessante para o

\footnotetext{
${ }^{127}$ LOBO, Jorge. Do Exercício do Direito de Voto das Ações Preferenciais com Dividendo Diferenciado. Revista de Direito Privado, 2003, vol. 15, pág. 214.

${ }^{128}$ CAMPOS, Luiz Antonio de Sampaio. Decisão do Colegiado em 17 de abril de 2003 referente ao MEMO/SEP/N ${ }^{\circ}$ 055/98, em 17 abr. 2003.

${ }^{129}$ TRINDADE, Marcelo Fernandez. Voto no âmbito do Processo Administrativo CVM No RJ $2005 / 7329$.
} 
acionista preferencial, tendo em vista que, conforme já exposto, este optou por receber vantagens ou preferências em relação às ações ordinárias, em troca da restrição ou perda do direito de voto.

No que tange a uma política de distribuição de menores dividendos, as vantagens e preferências patrimoniais referentes à prioridade de recebimento ou à distribuição de valor superior ao conferido às ações ordinárias continuarão existindo. Já no tocante à retenção integral de lucros, a recíproca não é verdadeira.

Mesmo que a estratégia de reinvestimento lucrativo gere riqueza para os acionistas, incluindo os preferenciais, há de se convir que o interesse de tais acionistas, ao restringirem ou suprimirem determinados direitos em troca de preferências ou vantagens patrimoniais, consiste em perceber os dividendos, em conformidade com as preferências ou vantagens atribuídas às suas ações.

Conforme expõe Eizirik, "a Lei no 6.404/76 adota posição semelhante à da teoria do mercado imperfeito, a qual enuncia que o valor da ação fundamenta-se, basicamente, nas expectativas futuras de pagamento de dividendos, que refletem a operação da companhia" ${ }^{\text {"130. }}$.

Portanto, verifica-se que o legislador optou por estabelecer a aquisição do direito de voto ou a suspensão das restrições no tocante às ações preferenciais com dividendo fixo ou mínimo, pois protegem seus titulares na hipótese (i) de inadimplemento da companhia, em realizar a distribuição de dividendos no prazo estabelecido no estatuto social, desde que não superior a três exercícios sociais consecutivos; e (ii) de políticas de reinvestimento lucrativo (em relação às companhias autorizadas, nos termos

${ }^{130}$ EIZIRIK, Nelson. Op. Cit., pág. 631. 
do II, do $\S 3^{\circ}$ do artigo 202 da Lei $\mathrm{n}^{0}$ 6.404/76) que desconfigurem o interesse do acionista por subscrever ou adquirir ações preferenciais. 


\section{Vantagens Superiores, Desproporção, Novo Mercado e Governança Corporativa}

\subsection{Das Vantagens Políticas Superiores - Golden Shares}

"As golden shares ou ações de classe especial consistem nas ações que conferem aos seus titulares o direito de veto ou privilégios sobre determinadas deliberações" 131 . "Tais ações foram concebidas em meados do século $\mathrm{XX}$, em diversos ordenamentos jurídicos estrangeiros, durantes as Grandes Guerras, com a finalidade de impedir a participação estrangeira nas companhias na época do nazifascismo" ${ }^{132}$.

A ação de classe especial foi incorporada ao ordenamento jurídico brasileiro com o advento da Lei $\mathrm{n}^{\circ} 8.031 / 90$, a qual instituiu o Programa Nacional de Desestatizações ("PND").

Conforme o enunciado do artigo $1^{\circ}$ da Lei $\mathrm{n}^{\circ} 8.031 / 90$, o PND tinha como finalidade: (i) reordenar a posição estratégica do Estado na economia, transferindo à iniciativa privada atividades indevidamente exploradas pelo setor público; (ii) contribuir para a redução da dívida pública, concorrendo para o saneamento das finanças do setor público; (iii) permitir a retomada de investimentos nas empresas e atividades que vierem a ser transferidas à iniciativa privada; (iv) contribuir para modernização do parque industrial do País, ampliando sua competitividade e reforçando a capacidade empresarial nos diversos setores da economia; (v) permitir que a administração pública concentre seus esforços nas atividades em que a presença do Estado seja fundamental para a consecução das prioridades nacionais; e (vi) fortalecer o

\footnotetext{
${ }^{131}$ EIZIRIK, Nelson. Op., Cit., pág. 169.

${ }^{132}$ RIPERT, Georges. Traité Élementaire de Droit Dommercial. Paris: Librairie Générale de Driot et de Jurisprudence, $1951,10^{\mathrm{a}} \mathrm{Ed}$.
} 
mercado de capitais, através do acréscimo da oferta de valores mobiliários e da democratização da propriedade do capital das empresas que integrarem o PND.

Assim sendo, a Lei $n^{\circ} 8.031 / 90$ autorizou a União Federal a privatizar companhias a entes privados. Nos termos do seu artigo $2^{\circ}$, privatizar consiste na alienação, pela União, de direitos que lhe assegurem, diretamente ou através de outras controladas, preponderância nas deliberações sociais e o poder de eleger a maioria dos administradores da companhia. Desse modo, convém destacar que as ações de classe especial ou golden shares foram incorporadas, inicialmente, no ordenamento jurídico brasileiro para viabilizar as privatizações.

Ainda de acordo com a Lei $n^{0} 8.031 / 90$, sempre que houvessem razões que o justifiquem, a União poderia deter, direta ou indiretamente, ações de classe especial do capital social de empresas privatizadas, que lhe conferissem poder de veto em determinadas matérias, as quais deveriam ser caracterizadas nos estatutos sociais das companhias privatizadas. Verificase através deste enunciado genérico que "a Lei $n^{\circ}$ 8.031/90 não disciplinou as hipóteses que justificariam a emissão da ação de classe especial, nem mesmo os direitos a ela inerentes"133.

Como ressalta Cantidiano, "sob a égide da Lei $\mathrm{n}^{\mathrm{o}}$ 8.301/90, foram emitidas ações de classe especial em três companhias privatizadas, quais sejam: (i) Companhia Eletromecânica Celma ("Celma"); (ii) Empresa Brasileira de Aeronáutica S.A. ("Embraer"); e (iii) Companhia Vale do Rio Doce ("Vale")"134.

\footnotetext{
${ }^{133}$ PELA, Juliana Krueger. As Golden Shares no Direito Societário Brasileiro. São Paulo: Quartier Latin do Brasil, 2012, pág. 64.

${ }^{134}$ CANTIDIANO, Luiz Leonardo. Reforma da Lei das S.A. Comentada. Rio de Janeiro: Renovar, 2002, pág. 88 .
} 
O edital da oferta de alienação das ações emitidas pela Celma enunciava que, após a privatização, seria conferida uma ação ordinária classe $\mathrm{B}$, à União, com direito de (i) veto em relação à alteração do objeto social e à alteração do limite de participação de companhias aéreas no capital da Celma, previsto no estatuto social; e (ii) indicar um membro para compor o conselho de administração da Celma.

Em relação à Embraer, o edital de oferta de alienação de suas ações determinava a criação de uma golden share a ser subscrita pela União, com direito de veto em relação (i) à mudança do objeto social; (ii) à alteração e/ou uso da logomarca da Embraer; (iii) à criação e alteração de programas militares; (iv) à capacitação de terceiros em programas militares; (v) à interrupção do fornecimento de peças de manutenção e reposição de aeronaves militares; (vi) à transferência de controle; e (vii) às modificações das prerrogativas da golden share ou da composição do conselho de administração da Embraer.

Já no que tange à Vale, o seu edital de oferta de alienação de ações previa que a União seria titular de uma participação (i) direta, por meio da subscrição de uma ação de classe especial emitida pela Vale; e (ii) indireta, por meio da subscrição de uma ação preferencial de classe A emitida pela companhia adquirente.

Nos termos do referido edital, a ação de classe especial conferia, à União, o direito de veto relativo à (i) alteração da denominação social; (ii) modificação da sede social; (iii) alteração do objeto social; (iv) liquidação da Vale; (v) alienação ou encerramento de determinadas atividades; e (vi) modificação das prerrogativas conferidas à ação de classe especial.

Já a ação preferencial classe A conferia, à União, o direito de deliberar sobre as seguintes matérias (i) alteração do objeto social; (ii) 
modificações nos limites de participação de acionistas no capital social; (iii) liquidação, dissolução e reorganização societária; (iv) modificação das regras de desconcentração aplicáveis aos acionistas; (v) alienação, oneração ou transferência de ações ordinárias emitidas pela Vale; e (vi) qualquer modificação dos direitos conferidos pela ação preferencial de classe A.

Convém destacar que o processo de privatização da Vale foi marcado por diversas discussões acerca de sua legalidade, principalmente, no que tange à possibilidade de emissão ou não de ações de classe especial $^{135}$. Em que pese as discussões existentes, o processo de privatização foi concluído, mediante a aquisição das ações ofertadas pela Valepar S.A., a qual emitiu, em favor da União, a ação preferencial classe A.

Posteriormente, a Lei $\mathrm{n}^{\circ} 8.031 / 90$ foi revogada com o advento da Lei $\mathrm{n}^{\mathrm{o}}$ 9.491/97, a qual "expandiu o alcance do PND, de modo a abranger a desestatização, ou seja, a transferência, ao setor privado da execução de serviços públicos explorados pela União"136.

Como bem ressalta Krueger, "o artigo $8^{\circ}$ da Lei 9.491/97 referiu-se genericamente a "poderes especiais" ao invés de mencionar apenas o poder de veto, demonstrando a intenção do legislador de incluir, dentre as prerrogativas da ação de classe especial, a de indicar membros para compor o conselho de administração das companhias privatizadas"137.

Atualmente, a ação de classe especial ou golden share encontra amparo legal no $\S 7^{\circ}$ do artigo 17 da Lei $n^{\circ} 6.404 / 76$, o qual foi introduzido

\footnotetext{
${ }^{135}$ A título de exemplo, citam-se os seguintes processos: (i) Ação Popular no 1997.39.00.12696-8, ajuizada perante a $1^{\mathrm{a}}$ Vara da Justiça Federal do Pará; e (ii) Ação de Inconstitucionalidade $n^{\mathrm{o}}$ 15974, ajuizada perante o Supremo Tribunal Federal.

${ }^{136}$ PELA, Juliana Krueger. Op. Cit., pág. 70.

${ }^{137}$ Ibid., pág. 71.
} 
pela Lei $\mathrm{n}^{\circ} 10.303 / 01$, consistindo na ação preferencial de classe especial, de propriedade exclusiva do ente desestatizante, que confere os poderes especificados no estatuto social, inclusive o de veto à deliberações da assembleia geral em determinadas matérias.

“A inclusão do $\S 7^{\circ}$ ao artigo 17 da Lei $n^{\circ}$ 6.404/76 teve por objetivo inserir, na legislação societária, o instituto das ações de classe especial ou golden shares, o qual já se encontrava previsto em nosso ordenamento" ${ }^{\text {"138. }}$. Porém, convém destacar a pertinência do comentário de Penteado, ao enunciar que "as ações de classe especial deveriam ter sido previstas no artigo 18 da Lei $n^{0} 6.404 / 76$ e não em seu artigo 17, uma vez que caracterizam direito políticos"

Como ressalta Eizirik "nos termos da Lei no 6.404/76, a golden share constitui, necessariamente, uma ação preferencial de classe especial, não sendo mais possível a criação de golden share de espécie ordinária" ${ }^{\# 14}$.

Ainda que o $\S 7^{\circ}$ do artigo 17 da Lei $\mathrm{n}^{\circ} 6.404 / 76$ verse sobre a emissão de ações de classe especial por companhias objeto de desestatização, tais ações podem ser utilizadas, inclusive, por outras companhias que não estejam inseridas nesse contexto. Nesse sentido, Coelho "defende a constituição de golden shares pelas companhias fechadas brasileiras que não sejam objeto de privatização, uma vez que o direito brasileiro não autoriza a discriminação de classe das ações ordinárias de acordo com o critério de veto e prerrogativas de deliberações sociais, a qual somente poderia ser feita pela utilização de ações preferenciais de classe especial" ${ }^{\prime 141}$.

\footnotetext{
${ }^{138}$ PELA, Juliana Krueger. Op. Cit., pág. 142.

${ }^{139}$ PENTEADO, Mauro Rodrigues. In Reforma da Lei das Sociedades Anônimas. Jorge Lobo (Coord.) Rio de Janeiro: Forense, 2003, pág. 195.

${ }^{140}$ EIZIRIK, Nelson. Op. Cit., pág. 170.

${ }^{141}$ COELHO, Fábio Ulhôa. Curso de Direito Comercial. São Paulo: Saraiva, 2007, v.2.
} 
Uma das companhias brasileiras que fizeram uso do instituto das ações de classe especial foi a Companhia Brasileira de Liquidação e Custódia ("CBLC"), a qual emitiu, em favor da Bolsa de Valores de São Paulo (atual BM\&FBovespa), a ação de classe especial conferindo vantagens patrimoniais, o direito de eleger membros para compor o conselho de administração e de aprovar, em votação em separado, determinadas matérias, com a finalidade de garantir a prestação dos serviços de compensação, liquidação, custódia e depósito.

Salomão Filho, em relação às ações de classe especial, ressalta que:

"Este instrumento é e tem sido recentemente utilizado como eficaz meio de recuperação de empresas em dificuldades. Nesses casos, frequentemente a imagem do controlador encontra-se tão desgastada que para a obtenção de crédito é fundamental não apenas uma mudança da administração, mas uma mudança de controle. A golden share fornece então instrumento eficaz e relativamente indolor para o controlador, já que ao mesmo tempo em que garante que esse não possa influir na administração, perdendo virtualmente todos os seus poderes, não implica perda do patrimônio do controlador, i.e, diluição ou redução de sua participação no capital da companhia",142.

Neste sentido, ressalta-se a emissão, pela Bicicletas Caloi S.A. (“Caloi”), de ação preferencial de classe especial atribuída à sociedade responsável pela sua recuperação, tendo em vista o estado de crise financeira em que a Caloi se encontrava, a qual conferia o direito de eleger mais de um membro de seu conselho de administração e o direito de veto a determinadas matérias, sendo conversível em ação ordinária uma vez rescindido ou terminado o contrato de gestão celebrado com a referida sociedade.

\footnotetext{
${ }^{142}$ SALOMÃO Filho, Calixto. O Novo Direito Societário. São Paulo: Malheiros, 2002, págs. 114 e 115 .
} 
Outra alternativa para a emissão de ações de classe especial por companhias privadas consiste em sua aplicação a operações estruturadas, como destaca Cantidiano:

"A prática societária em nosso País demonstra a ampla utilização do mecanismo aqui descrito [ação de classe especial], especialmente quando da realização de operações estruturadas, de que participam sociedades de propósito específico $(S P C)$, nas quais determinadas deliberações relevantes ficam submetidas ao poder de veto de alguns acionistas que exercem o papel de fiscais (ou trustes) dos interesses de terceiros, que negociam com tais sociedades. O exemplo mais eloquente de realização de operações dessa natureza é o de securitização de recebiveis, no qual a SPC funciona como veículo para permitir a captação de recursos no mercado, recursos esses que serão utilizados para adquirir da originadora os recebiveis que servirão de lastro da operação. Pois bem, a SPC emite uma ação especial de classe especial, que é atribuída aos representantes de seus credores (geralmente o agente fiduciário), para permitir que o referido representante dos credores possa vetar qualquer atuação da SPC que possa desvirtuar a finalidade de criação daquela sociedade, colocando em risco os interesses dos seus credores" $" 143$.

Conforme exposto acima, "as golden shares podem ser utilizadas em dois contextos (i) no âmbito de processos de privatização; ou (ii) entre particulares, por companhias que jamais contaram com participação estatal. Em cada um desses contextos, a função desempenhada pelo instrumento é diversa, pois, no primeiro caso, trata-se de modalidade de intervenção do Estado nas atividades estratégicas de companhias cujo controle acionário foi transferido ao setor privado; já no segundo caso, podem ser várias as funções do investimento, de acordo com a necessidade e demanda dos envolvidos" ${ }^{\prime 144}$.

Como exemplo de companhias que se enquadram na primeira hipótese, temos a Embraer, a Celma e a Vale, na qual há intervenção estatal para garantir que a consecução das atividades destas companhias atenda o interesse nacional, bem como que estrangeiros não tenham total ingerência de atividades estratégicas para o País.

\footnotetext{
${ }^{143}$ CANTIDIANO, Luiz Leonardo. Op. Cit., págs. 88 e 89.

${ }^{144}$ PELA, Juliana Krueger. Op. Cit., págs. 156 e 157.
} 
Em relação a segunda hipótese, a utilização de ações de classe especial pela CBLC teve como objetivo, em última instância, garantir que os serviços de compensação, liquidação, custódia e depósito fossem prestados continuamente. Já no que tange à Caloi, a emissão de ações de classe especial teve como finalidade garantir a recuperação da companhia, conferindo independência à sociedade responsável por geri-la temporariamente. Por fim, as ações de classe especial podem ainda ser utilizadas para proteger interesses de terceiros no que tange à celebração de contratos com a companhia emissora, conforme o entendimento de Cantidiano exposto acima.

Portanto, companhias abertas ou fechadas podem emitir golden shares conforme o contexto em que estão inseridas (leia-se processos de privatização ou atuação privada), sendo distinto, contudo, o fundamento legal para a emissão.

Para as companhias relacionadas a processos de privatização, o fundamento para a emissão de golden shares é o $\S 7^{\circ}$ do artigo 17 da Lei $n^{\circ} 6.404 / 76$, o qual dispõe, genericamente, que o estatuto social poderá conferir os poderes que especificar, inclusive o poder de veto a determinadas matérias, conferindo maior liberdade para a definição de quais direitos podem ser conferidos ao ente público titular da golden share. Nesse sentido, conforme expões Krueger, "não há qualquer predefinição na lei e, assim, o estatuto social poderá conferir os seguintes direitos (i) nomeação de administradores; (ii) poder de veto; (iii) aprovação ou ratificação de atos da administração; (iv) eleição de membros do conselho fiscal; ou (v) ingerência sobre a estrutura do capital social (em relação às companhias fechadas)" ${ }^{\prime 145}$.

\footnotetext{
${ }^{145}$ Ibid., pág. 161.
} 
Nesse sentido, Salomão Filho enuncia que

"Essa é a primeira forma possivel de golden share, a do artigo 17, $\$ 7^{\circ}$, que permite o controle externo de direito pelo ente desestatizante. Trata-se de um mecanismo regulatório-societário sem dúvida útil e relevante. Permite acrescentar o instrumento societário à disciplina regulatória, internalizando o interesse público ${ }^{\prime \prime 16}$

Em relação às companhias eminentemente privadas, a previsão legal para a emissão de golden shares reside no artigo 18 da Lei n ${ }^{\circ} 6.404 / 76$, o qual dispõe que o estatuto social pode assegurar o direito de (i) eleger, em votação em separado, membros dos órgãos da administração; e (ii) vetar determinadas alterações estatutárias. No entender de Krueger, "o estatuto também poderá conferir o direito de voto no tocante a modificações do capital social (em relação às companhias fechadas)"147.

Em sentido contrário, no que tange ao poder de voto da golden share com fundamento no artigo 18 da Lei $n^{\circ}$ 6.404/76, Salomão Filho enuncia que o "poder de veto é faculdade exclusiva do ente desestatizante. Não pode ser incluída (e essa interpretação já se impusera na vigência da lei anterior) entre os direitos políticos atribuídos às ações preferenciais pelo artigo $18^{148}$. Além disso, Salomão Filho destaca que "não é possível afirmar que o titular da golden share pode decidir privilegiadamente e singularmente sobre todas as matérias societárias que aprouver aos formuladores do estatuto, pois a Lei $n^{\circ} 6.404 / 76$ pretendeu reconhecer a prevalência dos minoritários apenas em caso de absenteísmo ou inexistência de controlador" ${ }^{149}$.

Por fim, ainda em relação ao direito de veto, Carvalhosa destaca que "nas companhias abertas ou fechadas, somente os titulares de ações

\footnotetext{
${ }^{146}$ SALOMÃO Filho, Calixto. Op. Cit., pág. 125.

${ }^{147}$ PELA, Juliana Krueger. Op. Cit., pág. 161.

${ }^{148}$ SALOM ÃO Filho, Calixto. Op. Cit., pág. 124.

${ }^{149}$ Ibid., pág. 127.
} 
preferenciais podem ter em assembleia especial de acionistas preferenciais o direito de veto em determinadas alterações estatutárias e, assim mesmo, apenas quando estas sejam de seu restrito interesse, como prevê o parágrafo único do artigo 18 da Lei $n^{\circ} 6.404 / 76^{1150}$.

Tendo em vista que o escopo do presente trabalho também reside em apresentar breves considerações sobre os interesse dos investidores, cabe indagar como a emissão de golden shares por companhias abertas influenciaria o interesse do investidor por subscrever ou adquirir ações da companhia emissora.

Nesse sentido, a Comissão Europeia solicitou à Oxera Consulting Ltd. a elaboração de um estudo ${ }^{151}$ com o objetivo de (i) fornecer uma visão sistemática dos direitos especiais mantidos pelo poder público em companhias privatizadas na União Europeia, bem como (ii) avaliar seus impactos econômicos sobre o desempenho das companhias afetadas.

De acordo com o referido estudo, "os direitos especiais mantidos pelo poder público podem ser classificados em (i) direitos de controlar as mudanças na estrutura acionária das companhias e influenciar nas decisões da administração; e (ii) restrições discriminatórias de investimentos estrangeiros" $^{152}$.

Conforme destacado pelo estudo, "os direitos especiais detidos pelas autoridades públicas tendem a ter um impacto negativo no desempenho

\footnotetext{
${ }^{150}$ CARVALHOSA, Modesto. Op. Cit., pág. 326.

${ }^{151}$ Oxera Consulting Ltd. Special Rights of Public Authorities in Privatized EU Companies: The Microeconomic Impact. págs. 1 - 109, nov. 2005. Disponível em: <http://ec.europa.eu/internal market/capital/docs/2005_10_special_rights_full_report_en.pdf.>. Acesso em 06 mai. 2014.

152 Ibid., págs. 3 e 4.
} 
econômico de longo prazo das companhias privatizadas, principalmente, em razão da interferência do Estado na companhia" ${ }^{153}$.

Além disso, o estudo aponta que "os direitos especiais podem constituir fortes barreiras ao investimento direto, tendo um impacto negativo para aquisições de controle acionário, bem como para formação de carteiras de investimento, na medida em que tais barreiras restringem a livre circulação de capitais e impedem maior integração do mercado" ${ }^{154}$.

Contudo, apesar dos efeitos negativos apontados, "o estudo ressalta que a criação de direitos especiais pelo poder público pode ser justificada em determinadas circunstâncias. Nesse sentido, as golden shares são uma boa alternativa para alinhar os interesses sociais e particulares no tocante às companhias que prestem serviços públicos essenciais, bem como para garantir o controle das decisões nas companhias que possam colocar em risco o interesse nacional" ${ }^{155}$.

No tocante à valorização/desvalorização das ações das companhias emissoras de golden shares, o referido estudo apontou "a ausência de evidências suficientes para auferir o impacto sobre as cotações de suas ações. Entretanto, o estudo concluiu que os direitos especiais tendem a influenciar de modo negativo o desempenho econômico de longo prazo das companhias privatizadas, em razão da ingerência estatal" ${ }^{156}$.

Em que pese a conclusão do estudo da Oxera no que tange ao impacto negativo sobre as cotações, convém destacar que as duas companhias abertas brasileiras emissoras de golden shares, quais sejam, a

\footnotetext{
153 Ibid., pág. 6.

154 Ibid., pág. 6.

155 Ibid., págs. 6 e 7.

156 Ibid., pág. 7.
} 
Vale e a Embraer, possuem 9,687\% e 1,536\% ${ }^{157}$, respectivamente, de representatividade na composição do Índice Bovespa - Ibovespa (índice composto por ações de companhias que atendam determinados critérios, inclusive, ter elevado volume financeiro - liquidez de negociação ${ }^{158}$ ).

Desse modo, apesar da ingerência estatal que as companhias mencionadas acima possuem, o seu elevado volume financeiro, ou seja, a grande quantidade de negócios efetuados, confirmam que as ações de companhias emissoras de golden shares podem ser atrativas para o público investidor.

\subsection{Das Vantagens Econômicas Superiores - Superpreferenciais}

O presente trabalho, em seu Capítulo 2 faz breves considerações sobre a decisão de capitalização das companhias para financiar a expansão de seus negócios, cabendo definir se os recursos serão captados via instrumentos de dívidas ou emissão de ações.

A Azul S.A. ("Azul”), companhia fechada do setor de aviação, optou pela captação de poupança no mercado, oferecendo ações preferenciais com restrições ao direito de voto, principalmente, em razão da limitação estabelecida pelo artigo 181 da Lei $\mathrm{n}^{\mathrm{o}} 7.565 / 86$, a qual impõe que, no mínimo, $80 \%$ das ações com direito de voto da companhia portadora de concessão devem ser detidas direta ou indiretamente por cidadãos brasileiros. Desse modo, a intenção da Azul consistiu em captar grandes quantidades de recursos necessários à expansão de suas atividades, sem que houvesse modificação de seu controle acionário.

\footnotetext{
${ }^{157}$ Conforme a composição do Ibovespa. Disponível em <http://www.bmfbovespa.com.br/ indices/ResumoCarteiraTeorica.aspx?Indice=IBOVESPA\&idioma=pt-br.> Acessado em 06 mai. 2014.

158 Conforme a Metodologia do Índice Bovespa. Disponível em: $<$ http://www.bmfbovespa.com.br/Indices/download/IBOV-Metodologia-pt-br.pdf.>. Acessado em 06 mai. 2014.
} 
Assim, em 24 de junho de 2013, a Azul protocolou, perante a CVM, pedido de registro de companhia aberta e de oferta pública de distribuição primária e secundária de ações preferenciais.

Nos termos do estatuto social da Azul, "são garantidas às ações preferenciais de sua emissão as seguintes vantagens: (i) prioridade no reembolso de capital; (ii) direito de serem incluídas em oferta pública de aquisição de ações em decorrência da alienação de controle da companhia nas mesmas condições e ao preço por ação equivalente a 75 vezes o preço por ação pago ao acionista controlador alienante; (iii) direito ao recebimento de valores equivalentes a 75 vezes o valor atribuído às ações ordinárias, em caso de liquidação da Azul, quando da divisão dos ativos remanescentes entre os acionistas; e (iv) direito ao recebimento de dividendos iguais a 75 vezes o valor pago a cada ação ordinária. Além disso, de acordo com o estatuto social da Azul as ações ordinárias são conversíveis em ações preferenciais, a critério dos respectivos titulares dessas ações, na proporção de 75 ações ordinárias para cada ação preferencial, desde que estejam inteiramente integralizadas e não haja violação à proporção legal de ações ordinárias e preferenciais"159.

Nesse sentido, a área técnica da CVM concluiu pelo indeferimento do pedido da oferta pública de distribuição de ações preferenciais e, consequentemente, do pedido de registro de companhia aberta da Azul, principalmente, em razão de entender que "a relação de 75:1 pode fazer com que, em um cenário em que o número de ações emitidas pela companhia seja de $50 \%$ de ações ordinárias e 50\% de ações preferenciais, o seu controle possa ser exercido com menos de $0,7 \%$ dos recursos aportados

\footnotetext{
${ }^{159}$ Estatuto Social da Azul, conforme encaminhado em conjunto com o pedido de registro perante a CVM, no âmbito do Processo Administrativo CVM Nº RJ2013/5993.
} 
no capital social da Azul, havendo, portanto um controlador com pouquíssima responsabilidade subsidiária"160.

Ademais, a área técnica entendeu que "uma diferença de $7.400 \%$ no dividendo a ser pago a cada uma das espécies de ações (preferenciais e ordinárias) ofenderia os princípios da razoabilidade e da proporcionalidade; bem como, que a diferença no preço de emissão entre as ações preferenciais e ordinárias não decorre da perspectiva de rentabilidade da companhia, nem do valor do patrimônio líquido da ação, mas sim de direitos patrimoniais e econômicos fixados pelo estatuto social da Azul na proporção de 75:1, em desacordo com o $\S 2^{\circ}$ do artigo 15 da Lei $n^{\circ} 6.404 / 76^{" 161}$.

Em 29 de outubro de 2013, a Azul interpôs recurso ao Colegiado, contra a decisão da área técnica, expondo que a emissão das ações preferenciais não violaria o disposto no $\S 2^{\circ}$ do artigo 15 da Lei $n^{\circ} 6.404 / 76$, tendo em vista os fundamentos a serem analisados a seguir.

Inicialmente, a Azul alegou que "o limite estabelecido pelo $\S 2^{\circ}$ do artigo 15 da Lei $n^{\circ}$ 6.404/76 refere-se exclusivamente ao número de ações preferenciais sem direito a voto, ou sujeitas a restrição desse direito, em relação ao número total de ações nas quais se divide o seu capital social" ${ }^{\text {"162 }}$. Em linha com este entendimento, Carvalhosa expõe que:

"O número de ações preferenciais sem direito de voto ou com restrições a esse direito é proporcional ao número de ações emitidas e não mais ao valor do capital social. O capital social deixou de ser referência para a fixação do percentual máximo de ações preferenciais sem ou com restrições de voto" ${ }^{163}$.

\footnotetext{
${ }^{160}$ Relatório de Análise CVM/SEP/GEA-2/No $111 / 2013$, elaborado no âmbito do Processo Administrativo CVM No RJ2013/5993.

${ }^{161}$ Ibid.

${ }^{162}$ Recurso interposto pela Azul ao Colegiado da CVM no âmbito do Processo Administrativo CVM No RJ2013/5993.

${ }^{163}$ CARVALHOSA, Modesto. Op. Cit., Op. Cit., 278.
} 
Assim sendo, de acordo com o entendimento acima exposto, o valor do capital social não pode ser considerado como referência para fixar o percentual de ações preferenciais sem ou com restrições de voto, mas sim o número de ações emitidas.

A Azul expõe ainda que "a Lei $\mathrm{n}^{\circ}$ 6.404/76, ao permitir preços de emissão diferentes entre as ações ordinárias e preferenciais (viabilizando, assim, o aumento substancial de ingressos de capital oriundos das ações preferenciais) admite desequilíbrio entre poder político dos acionistas e o volume de investimento realizado por eles" ${ }^{\prime 64}$.

Em relação as preferenciais ou vantagens conferidas pelas suas ações preferenciais, a Azul entende que "o legislador não estabeleceu limites máximos e, assim, reconheceu como possível e lícita a disparidade entre os direitos econômicos conferidos aos detentores de ações preferenciais em relação aos conferidos às ações ordinárias" ${ }^{\prime 165}$. Destaca-se que as vantagens econômicas na proporção de 75:1 foram concedidas tendo em vista o valor dos aportes financeiros realizados pelos acionistas subscritores das ações preferenciais, os quais representaram montantes superiores aos aportes realizados pelos subscritores de ações ordinárias.

Por fim, a Azul ressalta que a restrição no tocante à titularidade de ações do capital votante de concessionárias de serviços de transporte aéreo, prevista no artigo 181 da Lei $n^{0} 7.565 / 86$, “inviabiliza, na prática, que o capital social de uma companhia brasileira controladora de concessionárias de serviços regulares de transporte aéreo seja composto exclusivamente por ações ordinárias" $" 166$.

\footnotetext{
${ }^{164}$ Recurso interposto pela Azul ao Colegiado da CVM. Op. Cit.

165 Ibid.

${ }^{166}$ Ibid.
} 
Convém ressaltar que Eizirik e Cantidiano proferiram pareceres no âmbito do Processo Administrativo CVM No RJ2013/5993, solicitados pela Azul. Em relação ao limite de emissão de ações preferenciais previsto no $\S 2^{\circ}$ do artigo 15 da Lei no $6.404 / 76$, Eizirik expõe que:

\begin{abstract}
"Se o legislador tivesse a intenção de regular não apenas a proporção entre a quantidade de ações ordinárias e preferenciais que podem ser emitidas, mas, também, a proporção em termos de aporte econômico, a fim de que o poder político guardasse relação com os recursos aplicados na companhia, certamente teria incluído novo parágrafo no artigo $15 \mathrm{ou}$, principalmente, no artigo $17 \mathrm{da}$ Lei das S.A., com a finalidade de tratar desta matéria, fixando, por exemplo, um "teto" e não apenas um "piso", para as vantagens patrimoniais das ações preferenciais. Portanto, a partir do início da vigência da Lei $n^{\circ} 10.303 / 01$, o único limite legal para a emissão de ações preferenciais sem direito a voto ou com voto restrito passou a ser de 50\% do total de ações emitidas" $" 167$.
\end{abstract}

No mesmo sentido, Cantidiano defende que:

“(...) o limite de emissão, pela companhia, de ações preferenciais sem direito de voto está expressamente referenciado à quantidade total de ações de emissão da companhia. Não objetiva, a fixação do referido limite, de forma alguma, resguardar uma proporção entre poder politico e volume de recursos financeiros aplicados na companhia. Assinalo, ainda (...) que não pode, o poder público, interpretar dispositivo legal restritivo de direito alargando os conceitos nele contidos de modo a fazer com que seus efeitos sejam diversos daqueles que foram estabelecidos pelo legislador" ${ }^{\prime 68}$.

Após interposição do recurso pela Azul, a área técnica da CVM emitiu novo relatório, mantendo o entendimento pela improcedência do pedido de registro e de oferta, tendo em vista que "(i) a essência do $\S 2^{\circ}$ do artigo 15 da Lei $n^{\circ}$ 6.404/76 não trata somente de uma proporção em termos de quantidade de ações, mas também de um proporção em termos econômicos, no sentido de que o poder político deve guardar relação com o volume do recurso aplicado; e (ii) ao limitar a emissão de ações preferenciais a $50 \%$ do capital social, o legislador procurou limitar também a capacidade de alavancagem do acionista controlador em relação aos

\footnotetext{
${ }^{167}$ EIZIRIK, Nelson. Parecer proferido no âmbito do Processo CVM No RJ2013/5993.

${ }^{168}$ CANTIDIANO, Luiz Leonardo. Parecer proferido no âmbito do Processo Administrativo CVM $\mathrm{N}^{\circ} \mathrm{RJ} 2013 / 5993$.
} 
acionistas preferenciais, a $200 \%$ do capital por si subscrito e integralizado" $" 169$.

No mesmo sentido, a Procuradoria Federal Especializada da CVM emitiu parecer opinando "pela manutenção do indeferimento, por entender que (i) o critério de para fixação do limite de emissão de ações preferenciais sempre teve como premissa a relação existente entre participação no capital social e poder político do acionista; e (ii) a regra de limitação de emissão de ações preferenciais é de natureza cogente, uma vez que previne situações de conflito entre os acionistas sobre a distribuição do poder político na sociedade anônima, sendo essencial para a manutenção do equilíbrio do sistema jurídico da companhia, não podendo ser afastada por particular"170

Por seu turno, as Diretoras Novaes e Dias ${ }^{171}$ proferiram voto defendendo a legalidade das disposições do estatuto social da Azul que versam sobre a composição do capital social e as vantagens atribuídas às ações preferenciais sem direito de voto ou com restrições, conforme exposto a seguir.

Conforme bem observado por Novaes, "a estrutura proposta pela Azul é inovadora e atende as suas necessidades particulares tendo e vista as qualificações de seus administradores e o aporte de capital dos atuais acionistas minoritários que permitiram o crescimento da Azul. Para continuar esse crescimento, a Azul pediu o registro de companhia aberta", 172 .

\footnotetext{
${ }^{169}$ Relatório de Análise CVM/SEP/GEA-2/Nº131/2013, elaborado no âmbito do Processo Administrativo CVM No RJ2013/5993.

${ }^{170}$ Parecer emitido pela Procuradoria Federal Especializada da CVM no âmbito do Processo Administrativo CVM No RJ2013/5993.

${ }^{171}$ O Diretor Roberto Tadeu Antunes Fernandes acompanhou o voto da Diretora Ana Dolores Mora Carneiro de Novaes e o Diretor Leonardo P. Gomes Pereira declarou-se impedido.

172 NOVAES, Ana Dolores Moura Carneiro de. Voto no âmbito do Processo Administrativo CVM $\mathrm{N}^{\circ} \mathrm{RJ} 2013 / 5993$, em 28 jan. 2014.
} 
Em seu voto, Novaes enuncia que "há uma clara mudança na referência para o percentual de ações que podem ser emitidas: do capital social no Decreto-lei $\mathrm{n}^{\circ} 2.627 / 40$ para o número total de ações emitidas na Lei $n^{\circ} 6.404 / 76$, de modo que o entendimento da área técnica, no sentido de que a referência atual permanece sendo o capital social, não é a melhor interpretação. A partir do momento em que a Lei nº 6.404/76 admite ações sem valor nominal (artigo 11), não mais se pode assegurar uma proporcionalidade entre o capital aportado e o número de ações, isto é, o interesse econômico e o político. Consequentemente, a alteração da redação do $\S 2^{\circ}$ da Lei $n^{\circ}$ 6.404/76 era necessária para deixar claro que o limite percentual de ações preferenciais não mais se referia ao capital social, mas sim ao total de ações da companhia" ${ }^{, 173}$.

Nesse sentido, Dias expõe que "a interpretação feita pela área técnica da CVM no tocante ao $\$ 2^{\circ}$ do artigo 15 da Lei 6.404/76 possivelmente com a preocupação de selecionar estruturas de capital que alinhem melhor os interesses dentro de companhias, é desnecessária porque o mercado brasileiro já desenvolveu mecanismos próprios de fazer essa seleção" 174 .

Novaes comentou, ainda, que a principal conquista dos acionistas titulares de ações preferenciais, no tocante à reforma promovida pela Lei ${ }^{0}$ 10.303/01, conforme já exposto no presente trabalho, consiste em garantir vantagens ou preferências mínimas para que tais ações sejam admitidas à negociação no mercado de valores mobiliários, em especial, o dividendo diferenciado de, ao menos, $10 \%$ superior ao distribuído às ações ordinárias. Desse modo, Novaes enuncia que "a lei criou um piso, não um teto. Não caberia a CVM estabelecer limites quando a lei não o estabeleceu”.

\footnotetext{
173 Ibid.

${ }^{174}$ DIAS, Luciana. Voto no âmbito do Processo Administrativo CVM No RJ2013/5993, em 31 jan. 2014.
} 
Destaca-se, ainda, que a área técnica da CVM fundamentou o indeferimento do pedido de registro da Azul tendo como base potencial desalinhamento de interesses entre controlador e acionistas minoritários, em razão da ausência de proporcionalidade entre os direitos políticos e os aportes financeiros conferidos ao capital social da Azul. Em sentido contrário, Novaes expõe, acertadamente, que:

\footnotetext{
"O descumprimento dos deveres do acionista controlador e dos administradores deve ser prontamente apurado e julgado no devido processo sancionador conduzido por esta Autarquia [CVM]. Desvios do que é percebido potencialmente pelo mercado como pobre governança devem ser devidamente precificados pelo mercado. (...) Caso o controlador e a administração da Companhia [Azul] não se comportem à altura das expectativas do mercado, o múltiplo da Companhia [Azul] cairá. O risco deste potencial é dos investidores e do mercado que estão melhor habilitados a colocar um preço neste risco" ${ }^{\text {175 }}$.
}

Da mesma forma, Dias entende que a desproporção entre direitos econômicos e políticos não deve ser visto como algo ruim e fora do comum, pois "a existência somente de ações ordinárias não garante o alinhamento de interesses. Embora tal estrutura assegure os mesmos direitos políticos e econômicos na maioria dos casos, há inúmeros mecanismos possíveis para alavancar os poderes políticos de certos grupos dentro da companhia de modo lícito, os quais visam ou têm como consequência a dissociação entre contribuição econômica e poder político" ${ }^{176}$.

Outro fundamento apontado pela área técnica para fundamentar o indeferimento do pedido da Azul consiste na violação aos princípios da razoabilidade e da proporcionalidade, pela existência de uma diferença de $7.400 \%$ no dividendo a ser pago às ações preferenciais da Azul. De modo contrário, Novaes expõe que "a decisão da área técnica não parece ser a mais razoável e proporcional entre as possibilidades a seu alcance, tendo

\footnotetext{
${ }^{175}$ NOVAES, Ana Dolores Moura Carneiro de. Op. Cit.

${ }^{176}$ DIAS, Luciana. Op. Cit.
} 
em vista que não é certo que os acionistas minoritários se beneficiarão do indeferimento do pedido de registro da Azul. Do pondo de vista da Azul, a decisão é extremamente gravosa porque a impede de acessar o mercado de capitais, 177 .

Em linha com o exposto no presente trabalho no que tange ao interesse dos investidores, convém destacar o entendimento de Novaes:

\begin{abstract}
"A meu ver a proibição do registro não é a melhor forma de proteger o minoritário, pois o está privando de poder investir numa companhia que pode lhe ser atraente. Um potencial investidor pode ver a AZUL como uma companhia com gestão diferenciada, dividendos potencialmente maiores, crescimento, e outras tantas virtudes. Outro investidor pode ver a estrutura de governança da companhia de forma negativa e não investir nas ações da Companhia [Azul] Cabe à Companhia [Azul] informar o mercado de maneira clara e acessivel sobre as suas particularidades e à CVM fiscalizar esta obrigação por parte da Companhia [Azul]",178.
\end{abstract}

Portanto, ainda que a Azul tenha desistido da oferta pública de ações, em razões das condições econômicas do mercado, a decisão do Colegiado no âmbito do Processo Administrativo CVM No RJ2013/5993 representa um importante precedente para a emissão de superpreferenciais, ou seja, ações preferenciais que atribuem vantagens ou preferências econômicas muito superiores às ações ordinárias.

Conforme já exposto no presente trabalho, não se pode desprezar a capacidade dos investidores de avaliarem bons e maus investimentos e, muito menos, restringir as alternativas de captação de recursos por companhias injustificadamente, estabelecendo restrições que a lei não impôs.

Assim, o mecanismo da superpreferencial deve ser encarado como mais uma alternativa de alinhamento de interesses entre investidores e

\footnotetext{
${ }^{177}$ NOVAES, Ana Dolores Moura Carneiro de. Op. Cit.

${ }^{178}$ Ibid.
} 
emissores, tendo em vista que "estando presentes os mitigadores de desalinhamento entre a contribuição econômica e direitos políticos, como o direito de participar das ofertas públicas por alienação de controle, impedindo que o controlador se aproprie isoladamente do prêmio de controle, assim como o direito de votar em transações estratégicas para a companhia com maior potencial de expropriação dos não controladores, o desalinhamento entre direitos políticos e contribuição econômica estará devidamente contrabalanceado" 179 .

\subsection{Do Voto Plural e Desproporção}

No termos do artigo 110 da Lei $n^{\circ}$ 6.404/76, cada ação ordinária corresponde a um voto nas deliberações da assembleia geral, podendo o estatuto estabelecer limitação ao número de votos de cada acionista, sendo vedado a atribuição de voto plural a qualquer classe de ações.

Conforme enuncia Carvalhosa "o voto plural é o privilégio atribuído a determinadas ações, representado por um maior número de votos em relação às demais ações emitidas pela companhia"180.

Através da leitura do enunciado do artigo 110 da Lei $n^{0}$ 6.404/76, verifica-se a expressa vedação ao voto plural, a qual foi incialmente prevista no ordenamento jurídico brasileiro no artigo 80 do Decreto-lei $\mathrm{n}^{\mathrm{o}}$ 2.627/40, não podendo, os estatutos sociais, atribuírem um maior número votos à determinada classe de ações ordinárias.

Eizirik enuncia que "a proibição do voto plural consagra o princípio da proporcionalidade dos votos à participação no capital social, o que

\footnotetext{
${ }^{179}$ DIAS, Luciana. Op. Cit.

${ }^{180}$ CARVALHOSA, Modesto, Op. Cit., págs. 446 e 447; Apud Villegas, Aciones de voto plural. Buenos Aires: Depalma, 1973. 35; Cunha Peixoto, Sociedades por ações, Cit., v.2, pág. 355.
} 
permite uma melhor conciliação entre o poder e o incentivo para monitorar e fiscalizar o desempenho da companhia" ${ }^{\text {"181 }}$

O entendimento de Eizirik deriva da função econômica do direito de voto, já abordada no presente trabalho, de modo que o direito de voto tem como finalidade a orientação da consecução do objeto social da companhia, de modo a maximizar o lucro a ser auferido e, consequentemente, a ser distribuído aos acionistas. Assim, a escolha do legislador por estabelecer a igualdade entre os acionistas votantes reside, em última instância, em assegurar que tais acionistas tenham direitos políticos proporcionais ao capital investido na companhia.

Em que pese a decisão do legislador brasileiro ao optar pela vedação do voto plural, diversos ordenamentos jurídicos, inclusive os Estados Unidos, optaram por conferir aos emissores a liberdade de prever, em seus respectivos estatutos sociais, classes de ações ordinárias com números diferentes de votos.

Desse modo, diversas companhias norte americanas emitiram ações ordinárias com voto plural, como a Google Inc. ("Google") e, mais recentemente, a Facebook Inc. ("Facebook"), com a finalidade de permitir que seus fundadores detenham o controle, ainda que existam outros acionistas com direito de voto que tenham aportado maiores recursos financeiros.

A Google realizou seu IPO em 2004 ofertando classes de ações ordinárias com número de votos inferiores à classe de ações ordinárias

\footnotetext{
${ }^{181}$ EIZIRIK, Nelson. Op. Cit., pág. 619; Apud Clark, Robert Charles. Corporate Law. Boston: Little, Brown and Company, pág. 390.
} 
detidas por seus fundadores. De acordo com o form-10K 182 da Google cada ação ordinária classe $\mathrm{B}$ tem 10 votos por ação enquanto que cada ação ordinária classe A tem direito a um voto por ação.

Em 31 de dezembro de 2013, os fundadores da Google detinham, aproximadamente $92,2 \%$ da ações ordinárias classe B em circulação, representando, aproximadamente, $61,7 \%$ do poder de voto das ações ordinárias em circulação ${ }^{183}$.

Já a Facebook realizou seu IPO em 2012 e, da mesma forma que a Google, ofertou ações ordinárias com número de votos inferiores à classe de ações ordinárias detidas pelos seus fundadores. Em seu form-10K, consta que o titular de cada ação ordinária classe A tem direito a um voto, enquanto o titular de cada ação ordinária classe $\mathrm{B}$ tem direito a dez votos.

Consta na sessão de fatores de risco do form-10K da Facebook, que a concentração do poder político detida por Mark Zuckerberg (que além de fundador é também o Presidente do Conselho de Administração e Diretor Presidente) pode desencorajar potenciais investidores de adquirir ações ordinárias classe A em razão da desproporção do poder de voto destas ações em relação às ações ordinárias classe $B$ e pode, inclusive, prejudicar o valor de mercado de tais ações.

Certamente, há investidores que não comprariam as ações ordinárias de classe A da Facebook e da Google, em razão da concentração de poder político em seus fundadores. Nesse sentido, ao realizarem suas respectivas

\footnotetext{
${ }^{182}$ O Form-10K é uma espécie de formulário com informações relevantes, tais como a composição do capital social, os fatores de risco, membros da administração, etc., cuja apresentação à Securities Exchange Comission - SEC é obrigatória para as companhias abertas. No Brasil, a CVM exige a apresentação do Formulário de Referência, o qual tem a mesma finalidade e também contêm informações relevantes das companhias abertas.

${ }^{183}$ Form-10K da Google referente ao exercício social encerrado em 31 de dezembro de 2013. Disponível em <http://investor.google.com/pdf/ 20131231_google_10K.pdf>. Acessado em 06 mai. 2014.
} 
ofertas, tanto a Facebook ${ }^{184}$ quanto a Google ${ }^{185}$ foram alvo de diversas críticas dos defensores do princípio "uma ação um voto". Gorga expõe que:

"Hoje em dia, cientes que estão dos efeitos perversos que o uso de ações preferenciais não votantes em grandes proporções ocasiona ao mercado, os estudiosos de governança corporativa vêm recomendando a adoção de regras que objetivam impedir a severa dissociação entre direito de voto e investimento econômico. Assim, visando a fomentar o desenvolvimento dos mercados de capitais, ainda mais numa época marcada por acirrada competição, na qual se faz necessário expandir os mecanismos de captação de poupança para investimento produtivo, os ordenamentos jurídicos e os sistemas de regulação privados vêm adotando normas para restringir o uso de ações sem direito de voto ou om poder de voto desproporcional ${ }^{\prime 186}$.

Entretanto, convém refletir sobre os tais "efeitos perversos" que os defensores do princípio "uma ação um voto" argumentam que o voto plural ou até mesmo a restrição ou supressão de voto das ações preferenciais podem causar.

Em primeiro lugar, assim como existem investidores que jamais comprariam as ações ordinárias classe A da Google e da Facebook em razão da concentração de poder político em seus fundadores, para muitos outros, a razão principal de investirem em tais companhias é o fato de seus fundadores deterem o controle acionário, ou seja, para muitos investidores, os fundadores das companhias representam um ativo valioso, como destaca Novaes:

\begin{abstract}
"Embora os participantes de mercado, e eu aqui me inclua entre eles, possam perceber como salutares o princípio "uma ação, um voto" $e$ da proporcionalidade entre o poder político e o poder econômico, entendo que não há uma fórmula única que deva ser seguida por todos. No Brasil e no exterior há exemplos de companhias de sucesso em suas operações e no mercado de capitais nos quais há desvios destes princípios. As circunstâncias particulares delas permitem-nas desviarem destes princípios e mesmo assim serem negociadas com
\end{abstract}

\footnotetext{
${ }^{184}$ LAVELLE, Louis. Google's Governance Falls Way Short. Businessweek, 24 de agosto de 2012. Disponível em <http://www.businessweek.com/stories/2004-08-24/googles-governancefalls-way-short>. Acessado em 06 mai. 2014.

${ }^{185}$ SUROWIECKI, James. Unequal Shares. The New Yorker, 28 de maio de 2012. Disponível em $<$ http://www.newyorker.com/talk/financial/2012/05/28/120528ta_talk_surowiecki $>$. Acessado em 06 mai. 2014.

${ }^{186}$ GORGA, Érica. Op. Cit., pág. 159.
} 
múltiplos elevados. São exemplos claros as ações das companhias de tecnologia norte-americanas tais como a Google, Facebook e Groupon que adotam o voto plural, tornando dificil a perda do controle por parte dos acionistas fundadores. Aparentemente, o mercado não penaliza estas companhias, entendendo que a dificuldade para desalojar os acionistas fundadores é um ativo da companhia e não necessariamente algo pernicioso para a sua governança. Na mesma linha, na Europa, são exemplos de companhias de sucesso a Volkswagen, Louis Vuitton Möet Hennessy, e L'Oreal" ${ }^{\prime 187}$.

Corroborando o entendimento acima exposto, considerando o preço da emissão inicial das ações ordinárias classe A do Google de US\$ 85,00 até os dias de hoje (quase dez anos depois), há uma valorização acumulada de mais de 600\%, ou seja, um ganho de mais de seis vezes o valor inicialmente investido ${ }^{188}$. No que tange às ações ordinárias classe $\mathrm{A}$ da Facebook, considerando o preço da emissão inicial de US\$ 42,00 até os dias de hoje (quase dois anos depois), há uma valorização acumulada de, aproximadamente, $36,28 \%$, ou seja, um ganho de R\$ 15,00 por ação ${ }^{189}$.

Desse modo, é inegável que tais ações tenham sido aceitas pelo mercado, mesmo havendo uma outra classe ações ordinárias com 10 vezes mais votos por ação atribuídas aos fundadores das referidas companhias.

Em que pese a proibição do voto plural em alguns ordenamentos jurídicos, inclusive o brasileiro, a sua permissibilidade ou vedação está longe de ser pacificada. No ano passado (2013), o Comissário da União Europeia, Sr. Michel Barnier, divulgou seu posicionamento a favor da proposta de conceder direito de votos extras e uma fatia maior de dividendos aos acionistas de longo prazo. De acordo com o referido Comissário, o objetivo desta proposta é "é incentivar o investimento de

\footnotetext{
${ }^{187}$ NOVAES, Ana Dolores Moura Carneiro de. Op. Cit.

188 Histórico de Cotações GOOGL. Disponível em: <http://finance.yahoo.com/q/hp?s= GOOGL $\& \mathrm{a}=07 \& \mathrm{~b}=19 \& \mathrm{c}=2004 \& \mathrm{~d}=04 \& \mathrm{e}=10 \& \mathrm{f}=2014 \& \mathrm{~g}=\mathrm{d}>$. Acessado em 09 mai. 2014.

189 Histórico de Cotaçoes FB. Disponível em: <http://finance.yahoo.com/q/hp?s= FB+Historical+Prices>. Acessado em 09 mai. 2014.
} 
longo prazo, estabilizar bases acionárias das companhias e reduzir a volatilidade do mercado" ${ }^{\prime 190}$.

Portanto, em que pese a escolha do legislador brasileiro em proibir o instituto do voto plural, consagrando o princípio da proporcionalidade dos votos à participação no capital social, sobre a questão ainda restam muitas dúvidas, principalmente quanto aos efeitos negativos de sua permissibilidade. Conforme exposto acima, há hipóteses e companhias, como a Google e a Facebook, que estabeleceram em seus estatutos sociais classes de ações ordinárias com maior número de voto em relação às demais, visando a concentração de poderes políticos em seus fundadores, estratégia que, apesar das críticas, foi bem aceita pelo mercado, haja vista o histórico de valorização das respectivas ações após a realização das suas emissões iniciais. Ademais, destaca-se a discussão na Comissão Europeia a respeito do uso do voto plural para beneficiar estratégias de investimento de longo prazo, com a finalidade de reduzir a volatilidade da cotação das ações negociadas.

\subsection{Novo Mercado e Governança Corporativa}

Para entender os motivos que levaram a criação do Novo Mercado, em dezembro de 2002, e de outros seguimentos de listagem na bolsa brasileira, é necessário, primeiramente, compreender o contexto econômico e legal que a antecedeu.

No que tange ao cenário econômico, "a partir do início da década de 1990, estimulado pela perspectiva de privatização de empresas estatais de grande porte, o mercado de capitais do país havia recebido um significativo

\footnotetext{
190 ARNOLD, Martin. 'One Share, One Vote' Must Be Left Alone. Disponível em: $<$ http://www.ft.com/intl/cms/s/0/5024fd38-66ec-11e2-a83f-00144feab49a.html\#axzz31Ltc K6iV>. Acessado em 06 mai. 2014.
} 
influxo de investimento estrangeiro de portfólio, porém, o novo patamar de volume negociado nas bolsas brasileiras não se mostrou sustentável diante das sucessivas crises que atingiram os mercados emergentes e o próprio Brasil, especialmente, a partir da segunda metade de 1997"191.

Conforme ressalta Santana "no período de julho de 1997 e dezembro de 2000, o valor das ações negociadas na bolsa brasileira desvalorizou em cerca de 46,76\%, cabendo ressaltar que entre 1995 e 2000, somente oito companhias realizaram aberturas de capital no mercado brasileiro"192.

Já em relação ao contexto legal, “em 1997 foi realizada a reforma da Lei $\mathrm{n}^{\mathrm{o}}$ 6.404/76, perpetrada pela Lei $\mathrm{n}^{\circ}$ 9.457/97, a qual retirou dos acionistas minoritários diversos direitos com o objetivo de facilitar o processo de privatização" 193 .

“A premissa básica que norteou a criação do Novo Mercado foi de que a redução da percepção de risco por parte dos investidores influenciaria positivamente a valorização e a liquidez das ações negociadas, sendo que, de acordo com os seus idealizadores, a percepção de menor risco ocorreria graças a conferência de direitos e garantias adicionais concedidos aos acionistas e a uma redução na assimetria de informações entre controladores e administradores das empresas e participantes do mercado" $" 194$.

Nesse sentido, em dezembro de 2000 foi criado o segmento especial de listagem conhecido como Novo Mercado, no qual são listadas as ações ordinárias emitidas por companhias que voluntariamente adotam práticas de

\footnotetext{
${ }^{191}$ Santana, Maria Helena. Novo Mercado and Its Followers. In Focus 5, Global Corporate Governance Forum, IFC, 2008, pág. 2.

${ }^{192}$ Ibid., págs. 2 a 5 .

${ }^{193}$ DIAS, Luciana. Op. Cit.

${ }^{194}$ Santana, Maria Helena. Op. Cit., pág. 11.
} 
governança corporativa, além daquelas previstas em lei e se comprometem a não emitirem ações preferenciais.

Como bem observa Santana, em referência à emissão de ações ordinárias exclusivamente, "uma mudança dessa magnitude na composição do capital das companhias, embora perfeitamente possível para aquelas que fossem abrir o capital, não seria tão simples para as companhias já listadas na Bovespa (antiga BM\&FBovespa)"195.

Assim, de modo a garantir que as companhias cujas ações já estavam sendo negociadas também pudessem adotar práticas de governança corporativa, foram criados o Níveis Diferenciados de Governança Corporativa 1 e 2 , os quais tem como objetivo servirem de etapas para que tais companhias adaptem suas estruturas às práticas de governança corporativa do Novo Mercado, de forma gradual.

“As exigências do Nível 1 estão mais próximas da legislação brasileira e estão relacionadas à obrigações de divulgação de informações adicionais, ao passo que o Nível 2 exige das companhias a adesão a quase todas as obrigações previstas no regulamento do Novo Mercado, exceto pela possibilidade de manutenção das ações preferenciais, ou seja, as companhias listadas no Nível 2 podem emitir ações preferenciais, desde que a elas sejam assegurados o direito ao tag along de 100\% do preço da venda do controle e direito de voto em algumas situações relevantes"196.

\footnotetext{
${ }^{195}$ Ibid., pág. 12.

${ }^{196}$ Ibid., pág. 13.
} 
Desde a retomada das aberturas de capitais no mercado brasileiro, em 2004, até os dias de hoje, foram realizadas 151 IPO's, sendo 113 IPO's no âmbito do Novo Mercado, ou seja, aproximadamente $75 \%{ }^{197}$.

Em que pese a consistência do Novo Mercado, o fato de não serem admitidas companhias que tenham emitido ações preferenciais não pode ser tomado como um indicativo de que tais títulos não se coadunam com boas práticas de governança corporativa e alinhamento de interesses entre controladores, administradores, investidores e companhias emissoras.

Nesse sentido, o princípio uma ação, um voto representa uma alternativa para alinhar tais interesses, contudo, conforme já exposto acima, há diversos mecanismos lícitos de alavancagem de poderes políticos que podem ser implementados, os quais têm como objetivo ou consequência a dissociação entre contribuição econômica e poder político. Além disso, há diversas hipóteses em que somente a emissão de ações ordinárias inviabilizaria a captação de recursos por parte da companhia emissora, como no caso da Azul, por exemplo, dada a limitação em relação ao controle imposta por lei.

Em 2006, houve uma forte discussão a respeito das vantagens e desvantagens da adoção do princípio uma ação, um voto pela Comunidade Europeia, a qual encomendou um estudo ao escritório de advocacia Shearman \& Sterling LLP, nesse sentido ${ }^{198}$.

De acordo com o referido estudo, "são utilizadas diversas estruturas nas companhias listadas nos países integrantes da Comunidade Europeia, as

\footnotetext{
197 Pesquisa independente no site da BM\&FBovespa. Disponível em: <http://www.bm fbovespa.com.br/pt-br/mercados/acoes/ofertas-publicas/ofertas-publicas.aspx?Idioma=pt-bredfed $>$ Acessado em 06 mai. 2014.

${ }^{198}$ Shearman \& Sterling LLP. Proportionality Between Ownership and Control in EU Listed Companies" - Comparative Legal Study", págs. 1 - 18, 18 mai. 2007. Disponível em: $<$ http://www.ecgi.org/osov/documents/study_report_en.pdf.> Acessado em 06 mai. 2014.
} 
quais têm como consequência a dissociação entre a contribuição econômica e poderes políticos ${ }^{199}$. Dentre as estruturas utilizadas, destacam-se acordos de acionistas, estruturas piramidais, voto plural, ações preferenciais sem direito a voto e participações cruzadas.

Conforme enunciado pelo estudo, os acordos de acionistas, as participações cruzadas e as estruturas piramidais estão presentes em todos os países analisados, incluindo Estados Unidos, Japão e Austrália. Já as ações preferenciais sem direito de voto estão presentes em $84 \%$ dos países que participaram do estudo, enquanto que o voto plural está presente em $53 \%$.

Resumidamente, o estudo do Shearman \& Sterling LLP concluiu que "(i) nenhum dos países analisados adota, exclusivamente, o princípio uma ação um voto, de modo que há previsão de diversos mecanismos de alavancagem de poder político, cabendo às companhias e seus acionistas decidirem qual é a melhor forma de estruturação; (ii) nem todos os mecanismos previstos na legislação são efetivamente adotados pelas companhias, ou seja, o mercado tem a capacidade de avaliar e decidir quais mecanismos são atrativos ou não, cabendo ao emissor levar em consideração tal avaliação; e (iii) a adoção de tais mecanismos por parte das companhias emissoras é devidamente divulgada ao mercado" ${ }^{200}$.

No que tange ao ordenamento jurídico brasileiro, Dias desta que:

"É possivel alavancar direitos políticos de inúmeras outras formas. Uma forma bastante comum em outros países e que já começamos a perceber no mercado brasileiro é a utilização de contratos que alocam a exposição econômica para um sujeito e os direitos políticos para outro, tais como derivativos ou contratos de empréstimos de ações. (...) Acordos de acionistas e outros arranjos privados também podem assegurar o controle para certos agentes que detenham porcentagem expressiva do capital, mas não a maioria. (...) Há também a

\footnotetext{
199 Ibid.

${ }^{200}$ Ibid.
} 
possibilidade de se estabelecer cláusulas estatutárias que limitem o voto de todos os acionistas a uma porcentagem pequena do capital, de modo que mesmo quem detenha uma quantidade expressiva das ações somente vote com o teto préestabelecido. (...) Todos esses mecanismos (estruturas piramidais, derivativos, aluguel de ações, acordos de acionistas, limite estatutário para exercício do direito de voto) são perfeitamente lícitos e utilizados, em maior ou menor grau, por companhias brasileiras" ${ }^{201}$

Assim, verifica-se que em diversos ordenamentos jurídicos, inclusive o brasileiro, estruturas que têm como consequência a dissociação ente poderes políticos e o aporte de capital investido estão em conformidade com a legislação em vigor e são adotados por emissores, de acordo com a demanda do mercado. Conforme já exposto no presente trabalho, há que se considerar a capacidade do mercado de selecionar bons e maus investimentos e, convém destacar que o atual mercado brasileiro está bem mais evoluído do que aquele da década de 1990.

Além de "funcionarem como mecanismos de seleção, que auxiliam os investidores a identificar aquelas companhias que se propõem a respeitar certas regras que visam a trazer qualidade para a sua administração e a assegurar aos acionistas minoritários um tratamento mais equilibrado, os segmentos de listagem acabam tendo a função de identificar aquelas companhias com características especiais que justificam uma estrutura de capital diferenciada, sendo que os investidores parecem exigir dessas companhias um número ainda maior de compromissos, como no caso da Azul" ${ }^{202}$.

Os números dos IPO's realizados nos últimos anos no Brasil mostram, sem dúvidas, a predileção dos investidores por companhias com elevados padrões de governança corporativa. Poucas companhias que abriram capital nos últimos anos optaram por emitir ações preferenciais sem direito a voto ou com restrições e, as que emitiram, comprometeram-se em

\footnotetext{
${ }^{201}$ DIAS, Luciana. Op. Cit.

${ }^{202}$ Ibid.
} 
elevar o padrão de governança corporativa adotada, de modo a convencer aos investidores de que, apesar de terem emitidos ações preferenciais, promovem boa governança corporativa.

Em 2013, a KPMG Auditores Independentes divulgou um estudo sobre a governança corporativa e o mercado de capitais brasileiro, comparando os segmentos de listagem existentes no Brasil, de modo a verificar a frequência na aplicação de boas práticas de governança corporativa entre eles ${ }^{203}$. Sumariamente, o referido estudo concluiu que "a adoção de mecanismos de governança corporativa nos Níveis 1 e 2 são mais frequentes do que no Novo Mercado e no segmento Tradicional"204.

Ademais, convém destacar que diante da vedação da emissão de ações preferenciais sem direito de voto ou com restrições, previstas no regulamento do Novo Mercado, os antigos controladores das companhias listadas nesse segmento diluíram suas participações em razão da subscrição de novas ações ordinárias e, em muitos casos, o controle da companhia se tornou pulverizado, ou seja, mais da metade das ações que compõe seu capital social está negociada no mercado.

Em relação às companhias listadas no Novo Mercado que possuem capital pulverizado, é cada vez mais frequente o não comparecimento de seus acionistas nas assembleis gerais, ou seja, em boa parte das companhias cuja maioria das ações emitidas fazem parte do free float, verifica-se o fenômeno do absenteísmo. Conforme destaca Oioli, "o absenteísmo existe em razão da diferença de interesses entre acionistas empresários e acionistas capitalistas ou investidores, os quais não estão interessados em

\footnotetext{
${ }^{203}$ KPMG Auditores Independentes. A Governança Corporativa e o Mercado de Capitais, págs. 1 - 50, 2013. Disponível em: <http://www.kpmg.com/BR/PT/Estudos_Analises/artigosepublicacoes/ Documents/Risk-Consulting/A-Governanca-Corporativa-e-o-Mercado-de-Capitais-13-14.pdf.> Acessado em 06 mai. 2014.

${ }^{204}$ Ibid., pág. 6.
} 
comparecer às assembleias, mas sim em receber dividendos auferidos pela companhia na qual investem" 205 .

Assim sendo, a existência de um segmento de listagem, no qual todas as ações listadas possuem direito de voto, não faz com que os investidores exerçam seu voto, ou seja, em que pese a emissão exclusiva de ações ordinárias, sempre haverá investidores que não têm interesse em deliberar sobre a gestão e consecução das atividades sociais, os quais mesmo subscrevendo ações ordinárias, não comparecem às assembleias.

Portanto, em que pese a bem sucedida criação do Novo Mercado, não se deve conceber o princípio "uma ação um voto" como uma meta a ser atingida por todas as companhias abertas brasileiras, de modo que as teorias que visam a extirpação das ações preferenciais sem direito de voto ou com restrições não merecem prosperar, tendo em vista que (i) o Novo Mercado deve ser encarado como mais uma alternativa aos emissores e investidores para alinharem seus interesses; (ii) a emissão exclusiva de ações ordinárias pode inviabilizar a captação de recursos por diversas companhias que necessitem de uma estrutura de capital diferente; (iii) houve, nos últimos anos, um amadurecimento do mercado de capitais brasileiro, de modo que os investidores passaram a ser mais exigentes fazendo com que as companhias, que necessitem ou pretendem captar recursos por meio de mecanismos que elevam a dissociação entre poderes políticos e contribuição econômica, compensem com a elevação do padrão das práticas de governança corporativa; e (iv) o absenteísmo nas assembleias das companhias listadas no Novo Mercado comprovam que nem todos os investidores prezam por direitos políticos.

\footnotetext{
${ }^{205}$ OIOLI, Erik Frederico. Oferta Pública de Aquisição do Controle de Companhias Abertas. Coleção IDSA de Direito Societário e Mercado de Capitais, v. 1. São Paulo: Quartier Latin, 2010, pág. 35.
} 


\section{Conclusão}

As companhias tem a necessidade de financiar a expansão de seus negócios. Se suas atividades forem bem conduzidas, pode ser que esta consiga arcar com os custos de sua expansão por meio dos lucros gerados; do contrário, a companhia terá que obter financiamento externo, o qual poderá ser obtido por meio de dívidas ou emissão de ações.

Da perspectiva do empresário empreendedor, utilizar instrumentos de dívida ao invés de emitir ações significa preservar o controle da companhia e evitar a diluição da participação, porém, elevando o risco de falência da companhia, tendo em vista que os instrumentos de dívida estabelecem datas de vencimento para o pagamento do principal acrescido de juros.

Mediante a emissão de ações preferenciais, as companhias podem obter capital próprio, o qual tem a vantagem de não ser restituído se a companhia falhar em gerar receita suficiente, ao contrário dos instrumentos de dívida, ao passo que, o controle da companhia será mantido nas mãos do empresário-empreendedor, o qual tem a expertise e o interesse para conduzir as atividades sociais, desde que os dividendos preferenciais sejam pagos.

Caso a companhia opte por emitir ações, estas serão subscritas pelos empresários-investidores, os quais, em geral, não têm a expertise necessária nem o interesse em interferir diretamente na condução das atividades da companhia, ou seja, visam apenas aplicar capital em troca de retorno econômico futuro e desejam que o empresário-empreendedor e os administradores da companhia a mantenham lucrativa e respeitem seus direitos, pois, do contrário, alienarão suas ações. 
Assim, tais investidores são motivados a investir seus recursos, por meio de subscrição de ações preferenciais sem direito de voto ou com restrições, com a intenção de obter vantagens ou preferências, deixando os acionistas com a expertise e o interesse, necessários à consecução do objeto social e da gestão da companhia, tomarem as decisões através do exercício do voto.

De modo geral, o direito de voto desempenha a função econômica de possibilitar aos acionistas, em última instância, a orientação da consecução do objeto social, de modo a maximizar o lucro a ser auferido pela companhia e, consequentemente, a ser atribuído aos acionistas.

O fundamento da concepção das ações preferenciais reside na possibilidade de o acionista ter determinados direitos restringidos e, em troca, receber vantagens ou preferências patrimoniais e/ou políticas. Desse modo, o acionista titular de ação preferencial com restrição ou exclusão do direito de voto, abre mão deste direito, que provavelmente não usaria, para auferir vantagens patrimoniais e políticas, de acordo com seus interesses.

Nos da Lei $n^{\circ} 6.404 / 76$, as vantagens patrimoniais que podem ser conferidas às ações preferenciais sem direito de voto ou com restrições consistem em: (i) prioridade na distribuição de dividendo, fixo ou mínimo; (ii) prioridade no reembolso de capital, com prêmio ou sem ele; (iii) direito de participar do dividendo a ser distribuído, correspondente a, pelo menos, $25 \%$ do lucro líquido do exercício, calculado na forma do artigo 202 da Lei $\mathrm{n}^{\mathrm{o}}$ 6.404/76, de acordo com o seguinte critério: (a) prioridade no recebimento do dividendo correspondente a, no mínimo, 3\% do valor de patrimônio líquido da ação; e (b) direito de participar, em igualdade de condições com ações ordinárias, do lucro distribuído que remanescer depois de asseguradas às ações ordinárias dividendo igual ao mínimo prioritário; 
(iv) direito ao recebimento de dividendo, por ação preferencial, pelo menos 10\% maior que o atribuído a cada ação ordinária; e (v) direito de serem incluídas na oferta pública de alienação de controle, nos termos do artigo 254-A da Lei $n^{\circ}$ 6.404/76, assegurado o dividendo pelo menos igual ao das ações ordinárias.

Já as vantagens políticas que podem ser conferidas aos titulares das ações preferenciais não votantes ou com restrições consistem em (i) eleger, em votação em separado, um ou mais membros dos órgão de administração da companhia; e/ou (ii) subordinar determinadas alterações estatutárias a sua aprovação, em assembleia especial.

Convém destacar que a Lei n ${ }^{0}$ 6.404/76 obriga a atribuição, às ações preferenciais sem direito de voto ou com restrições que venham a ser emitidas por companhias abertas, de ao menos uma das vantagens dentre as constantes nos itens (iii) a (v) acima, para que tais ações sejam admitidas à negociação no mercado de valores mobiliários.

Desse modo, verifica-se que a Lei $n^{\circ}$ 6.404/76 confere liberdade aos emissores, no sentido de ampliar as alternativas de capitalização; enquanto que o mercado se encarrega escolher quais são os instrumentos mais interessantes e vantajosos. Ressalta-se que tais vantagens políticas podem ser atribuída a companhias abertas ou fechadas.

Entretanto, em que pese a escolha do legislador em prever a existência das ações preferenciais sem direito de voto ou com restrições, há correntes doutrinárias que defendem a sua extinção, por entenderem que sua emissão acarreta em desalinhamento de interesses, pois seus subscritores, de modo geral, abrem mão do direito de voto para receberem vantagens patrimoniais. 
Nesse sentido, a desproporção entre direitos econômicos e políticos não deve ser vista como algo ruim e fora do comum, uma vez que "a existência somente de ações ordinárias não garante o alinhamento de interesses. Embora tal estrutura assegure os mesmos direitos políticos e econômicos na maioria dos casos, há inúmeros mecanismos possíveis para alavancar os poderes políticos de certos grupos dentro da companhia de modo lícito, os quais visam ou têm como consequência a dissociação entre contribuição econômica e poder político" ${ }^{206}$.

Dentre tais mecanismos, o presente trabalho apresentou breves considerações sobre (i) as golden shares; (ii) as superpreferenciais; e (iii) o voto plural.

"As golden shares podem ser utilizadas em dois contextos (i) no âmbito de processos de privatização; ou (ii) entre particulares, por companhias que jamais contaram com participação estatal. Em cada um desses contextos, a função desempenhada pelo instrumento é diversa, pois, no primeiro caso, trata-se de modalidade de intervenção do Estado nas atividades estratégicas de companhias cujo controle acionário foi transferido ao setor privado; já no segundo caso, podem ser várias as funções do investimento, de acordo com a necessidade e demanda dos envolvidos"207.

Em que pese a ingerência estatal, as duas companhias abertas brasileiras que emitiram golden shares (Vale e Embraer) apresentam elevado volume financeiro, confirmando que as ações de tais companhias podem ser atrativas para o público investidor.

\footnotetext{
${ }^{206}$ DIAS, Luciana. Op. Cit.

${ }^{207}$ PELA, Juliana Krueger. Op. Cit., págs. 156 e 157.
} 
Já as superpreferenciais deve ser encaradas como mais uma alternativa de alinhamento de interesses entre investidores e emissores, tendo em vista que "estando presentes os mitigadores de desalinhamento entre a contribuição econômica e direitos políticos, como o direito de participar das ofertas públicas por alienação de controle, impedindo que o controlador se aproprie isoladamente do prêmio de controle, assim como o direito de votar em transações estratégicas para a companhia com maior potencial de expropriação dos não controladores, o desalinhamento entre direitos políticos e contribuição econômica estará devidamente contrabalanceado" ${ }^{208}$.

No que tange ao voto plural, em que pese a decisão do legislador brasileiro ao optar pela vedação do voto plural, diversos outros ordenamentos jurídicos, inclusive os Estados Unidos, optaram por conferir aos emissores a liberdade de prever em seus respectivos estatutos sociais classes de ações ordinárias com números diferentes de votos, tais como a Google e a Facebook.

Assim como existem investidores que jamais comprariam as ações ordinárias classe A da Google e Facebook em razão da concentração de poder político em seus fundadores, para muitos outros a razão principal de investirem em tais companhias é o fato de seus fundadores deterem o controle acionário, ou seja, para muitos investidores, os fundadores das companhias representam um ativo valioso.

Há de se considerar que "embora os alguns participantes do mercado possam perceber como salutares o princípio uma ação um voto e da proporcionalidade entre o poder político e o poder econômico, há exemplos de companhias de sucesso em suas operações e no mercado de capitais nos

${ }^{208}$ DIAS, Luciana. Op. Cit. 
quais há desvios destes princípios, as quais não são penalizadas pelo mercado, pois a dificuldade para desalojar os acionistas fundadores é um ativo da companhia e não necessariamente algo pernicioso para a sua governança",209.

Além de servir como forma de dificultar que os acionistas fundadores detenham o controle, o voto plural também pode ser utilizado para "incentivar o investimento de longo prazo, estabilizar bases acionárias das companhias e reduzir a volatilidade do mercado" ${ }^{210}$, caso sejam atribuídos votos extras aos acionistas de longo prazo, como está sendo discutido na Comunidade Europeia.

Desse modo, verifica-se que em diversos ordenamentos jurídicos, inclusive o brasileiro, há previsão legal de estruturas que têm como consequência a dissociação ente poderes políticos e o aporte de capital investido, as quais podem ou não ser utilizadas de acordo com a demanda do mercado. Conforme já exposto no presente trabalho, há que se considerar a capacidade do mercado de selecionar bons e maus investimentos e, convém destacar que o atual mercado brasileiro está bem mais evoluído do que aquele da década de 1990.

Os números dos IPO's realizados nos últimos anos no Brasil mostram, sem dúvidas, a predileção dos investidores por companhias com elevados padrões de governança corporativa. Poucas companhias que abriram capital nos últimos anos optaram por emitir ações preferenciais sem direito a voto ou com restrições e, as que emitiram, comprometeram-se em elevar o padrão de governança corporativa adotada, de modo a convencer aos investidores de que, apesar de terem emitidos ações preferenciais, promovem boa governança corporativa.

\footnotetext{
${ }^{209}$ NOVAES, Ana Dolores Moura Carneiro de. Op. Cit.

${ }^{210}$ ARNOLD, Martin. Op. Cit.
} 
Dentre os fatores que contribuíram para o amadurecimento do mercado brasileiro, cita-se a criação do Novo Mercado, a qual tem como "premissa básica o fato de que a redução da percepção de risco por parte dos investidores influenciaria positivamente a valorização e a liquidez das ações negociadas, sendo que, de acordo com os seus idealizadores, a percepção de menor risco ocorreria graças a conferência de direitos e garantias adicionais concedidos aos acionistas e a uma redução na assimetria de informações entre controladores e administradores das empresas e participantes do mercado" ${ }^{211}$.

Em que pese a consistência do Novo Mercado, o fato de não serem admitidas companhias que tenham emitido ações preferenciais não pode ser tomado como um indicativo de que tais títulos não se coadunam com boas práticas de governança corporativa e alinhamento de interesses entre controladores, administradores, investidores e companhias emissoras.

Nesse sentido, o princípio uma ação, um voto representa uma alternativa para alinhar tais interesses, contudo, conforme já exposto ao longo do presente trabalho, há diversos mecanismos lícitos de alavancagem de poderes políticos que podem ser implementados, os quais têm como objetivo ou consequência a dissociação entre contribuição econômica e poder político. Além disso, há diversas hipóteses em que somente a emissão de ações ordinárias inviabilizaria a captação de recursos por parte da companhia, como no caso da Azul, por exemplo, dada a limitação em relação ao controle imposta por lei.

Destaca-se, ainda, o não comparecimento dos acionistas nas assembleias gerais das companhias com controle disperso que estão listadas

${ }^{211}$ SANTANA, Maria Helena. Op. Cit., pág. 11. 
no Novo Mercado, o qual decorre da existência de acionistas que não têm interesse em participar da gestão das companhias e, consequentemente, das suas assembleias gerais, porém, subscreveram ações ordinárias em razão das regras de autorregulação do Novo Mercado.

Isto posto, tem-se que a complexidade dos interesses dos integrantes do mercado de capitais brasileiro não pode ser satisfeita por meio do princípio uma ação um voto, de modo que as teorias que visam a extirpação das ações preferenciais sem direito de voto ou com restrições não merecem prosperar, pois a emissão exclusiva de ações ordinárias (i) restringe ou até mesmo inviabiliza a captação de recursos por diversas companhias que necessitem de uma estrutura de capital diferente; e (ii) ignora a preferência dos investidores que não estão interessados em participar da gestão da companhia. 


\section{Bibliografia}

ARAGÃO, Paulo Cezar. In A Reforma da Lei das S.A. Jorge Lobo (Coord.). Rio de Janeiro: Atlas, 2003, 2a Edição, págs. 158 a 169.

ARNOLD, Martin. 'One Share, One Vote’ Must Be Left Alone. Disponível em: $\quad<$ http://www.ft.com/intl/cms/s/0/5024fd38-66ec-11e2-a83f-00144fea b49a.html\#a xzz31Ltc K6iV>. Acessado em: 06 mai. 2014.

Bolsa de Valores do Rio de Janeiro. Observações sobre o Anteprojeto da Lei das Sociedades Anônimas. Jornal do Brasil, págs. 36 - 37, 21 de mar. de 1976.

BRUSCHI, Gilberto Gomes. Dividendos Das Ações Preferenciais na Lei 10.303/2001. Revista de Direito Privado, 2003, vol. 16, págs. 115 - 139.

CAMPOS, Luiz Antonio de Sampaio. Decisão do Colegiado referente ao MEMO/SEP/Nº 055/98, em 17 abr. 2003.

CANTIDIANO, Luiz Leonardo. Parecer proferido no âmbito do Processo Administrativo CVM No RJ2013/5993.

CANTIDIANO, Luiz Leonardo. Reforma da Lei das S.A. Comentada. Rio de Janeiro: Renovar, 2002, pág. 88.

CANTIDIANO, Luiz Leonardo. Revista Abamec-RJ, Outubro de 1997.

CARVALHOSA, Modesto, Op. Cit., págs. 446 e 447; apud Villegas, Aciones de voto plural. Buenos Aires: Depalma, 1973. 35; Cunha Peixoto, Sociedades por ações, Cit., v.2, pág. 355. 
CARVALHOSA, Modesto. Ações Preferenciais Desprovidas de Preferências. Revista dos Tribunais, 1994, vol. 707, págs. 41 - 45.

CARVALHOSA, Modesto. Comentários à Lei das Sociedades Anônimas. São Paulo: Saraiva, 2011, 5 Edição, vol. 1, págs. 289 - 342 e vol. 2, págs. $334-654$.

COELHO, Fábio Ulhôa Coelho. Parecer nos autos da Ação Ordinária 951/2000 que tramitou perante a $1^{\text {a }}$ Vara Cível da Comarca de Mirassol, Estado de São Paulo.

COELHO, Fábio Ulhôa. Curso de Direito Comercial. São Paulo: Saraiva, 2007, v.2.

COMPARATO, Fabio Konder; SALOMÃO Filho, Calixto. O Poder de Controle na Sociedade Anônima. Rio de Janeiro: Forense, 2005, págs. 315 -372 .

DA COSTA, Philomeno J. Anotação às Companhias. Revista dos Tribunais, 1980, vol. I, págs. $290-300$.

DIAS, Luciana. Voto no âmbito do Processo Administrativo CVM No RJ2013/5993, em 31 jan. 2014.

Dodge v. Ford Motor Co., 204 Mich. 459, 170 N.W. 688, 1919.

EASTERBROOK, Frank H.; FISCHEL, Daniel R. The economic structure of corporate law. Cambridge: Harvard University Press, 1991, págs. 1 - 68.

EIZIRIK, Nelson. A Lei das S/A Comentada. São Paulo: Quartier Latin do Brasil, 2011, vol. I, pág. 153 - 184 e vol. III, pág. 76 - 150. 
EIZIRIK, Nelson. Parecer proferido no âmbito do Processo Administrativo CVM No RJ2013/5993.

FERREIRA, Waldemar. Tratado de Direito Comercial. São Paulo: Saraiva, 1961, vol. 4, págs. $200-239$.

FERREIRA, Waldemar. Tratado de Sociedade Mercantis. Rio de Janeiro: Freitas Bastos 1958, vol. IV, págs. 1350 - 1398.

FRAGOSO, Daniela Neves Reali. AKKERMAN, Gustavo. Ações Preferenciais: Evolução ou Retrocesso?. In Temas de Direito Societário e Empresarial Contemporâneos. São Paulo: Malheiros, 2011, págs. 278 297.

GORGA, Érica. Direito Societário Atual. Rio de Janeiro: Elsevier, 2013, págs. $135-170$.

GRAHAM, Benjamin. O Investidor Inteligente. Rio de Janeiro: Nova

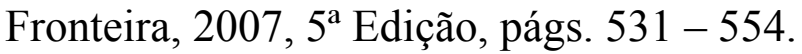

KPMG Auditores Independentes. A Governança Corporativa e o Mercado de Capitais, págs. 1 - 50, 2013. Disponível em: <http://www.kpmg.com/BR /PT/Estudos_Analises/artigosepublicacoes/Documents/Risk-Consulting/AGovernanca-Corporativa-e-o-Mercado-de-Capitais-13-14.pdf.>. Acessado em 06 mai. 2014.

LAMY, Alfredo; PEDREIRA, José Luiz Bulhões. A Lei das S.A. Rio de Janeiro: Renovar, $3^{\text {a }}$ Edição, 1997, págs. 65 - 72. 
LAMY, Alfredo; PEDREIRA, José Luiz Bulhões. Direito das Companhias. Rio de Janeiro: Forense, 2009, vol. 1 e 2, págs. 242 - 1720.

LAMY, Alfredo; PEDREIRA, José Luiz Bulhões. Função Empresarial e Ações Preferenciais. Jornal do Brasil, 28 de mar., 03 e 04 de abr. de 1976.

LAVELLE, Louis. Google's Governance Falls Way Short. Businessweek, 24 de agosto de 2012. Disponível em <http://www.businessweek.com/ stories/2004-08-24/googles-governance-falls-way-short.

LEÃES, Luis Gastão Paes de Barros. Do Direito do Acionista ao Dividendo. São Paulo: Obelisco, 1969, págs. $301-310$.

LEÃES, Luiz Gastão Paes de Barros. Ações Preferenciais Exclusivamente com Vantagens Políticas. Pareceres. São Paulo: Singular, 2004, vol. II, págs. $841-845$.

LEME, Ernesto. Das Acções Preferenciais nas Sociedades Anonymas. São Paulo: Saraiva, 1933, págs. $20-30$.

LOBO, Jorge. Do Exercício do Direito de Voto das Ações Preferenciais com Dividendo Diferenciado. Revista de Direito Privado, 2003, vol. 15, págs. $212-216$.

LUCENA, José Waldecy. Das Sociedades Anônimas - Comentários à Lei. Rio de Janeiro: Renovar, 2009, vol. 1, págs. 270 - 290.

MILLER, Merton; MODIGLIANI, Franco. Dividend Policy, Growth and Valuation of Shares. Journal of Business, v. 34, págs. 411 - 433, out. 1961. Disponível em: 
$<$ http://student.bus.olemiss.edu/files/fuller/div/Miller\%20and\%20Modi gliani\%201961.pdf>. Acessado em 06 mai. 2014.

MÜSSNICH, Francisco Antunes Maciel. Reflexões Sobre o Direito de Recesso na Lei das Sociedades por Ações. In Reforma da Lei das Sociedades Anônimas. Jorge Lobo (Coord.). Rio de Janeiro: Forense, $2^{\mathrm{a}}$ Edição.

NOVAES, Ana Dolores Moura Carneiro de. Voto no âmbito do Processo CVM Nº RJ2013/5993, em 28 jan. 2014.

OIOLI, Erik Frederico. Oferta Pública de Aquisição do Controle de Companhias Abertas. Coleção IDSA de Direito Societário e Mercado de Capitais, v. 1. São Paulo: Quartier Latin, 2010, págs 28 - 40.

Oxera Consulting Ltd. Special Rights of Public Authorities in Privatized EU Companies: The Microeconomic Impact, págs. 1 - 109, nov. 2005. Disponível em: <http://ec.europa.eu/internal_market/capital/docs/2005_10_ special_rights_full_report_en.pdf.>. Acesso em 06 mai. 2014.

PARENTE, Norma. Voto no âmbito do Processo Administrativo CVM RJ 2002/2941, em 21 out. 2002.

PEDREIRA, José Luiz Bulhões. Finanças e Demonstrações Financeiras da Companhia. Rio de Janeiro: Forense, 1989, págs. 380 - 410.

PELA, Juliana Krueger. As Golden Shares no Direito Societário Brasileiro. São Paulo: Quartier Latin do Brasil, 2012, pág. 64.

PENTEADO, Mauro Rodrigues. In Reforma da Lei das Sociedades Anônimas. Jorge Lobo (Coord.) Rio de Janeiro: Forense, 2003, pág. 195. 
RETTO, Marcel Gomes Bragança. Evolução Legislativa das Ações Preferenciais no Brasil e os Institutos a Elas Relacionados. Revista de Direito Mercantil, Industrial, Econômico e Financeiro, 2004, vol. 133, págs. $122-130$.

RIPERT, Georges. Traité Élementaire de Droit Dommercial. Paris: Librairie Générale de Driot et de Jurisprudence, 1951, 10ª Edição.

SALOMÃO Filho, Calixto. O Novo Direito Societário. São Paulo: Malheiros, 2002, págs. 114 e 115.

SANTANA, Maria Helena. Novo Mercado and Its Followers. In Focus 5, Global Corporate Governance Forum, IFC, 2008, págs. 1 - 27.

Shearman \& Sterling LLP. Proportionality Between Ownership and Control in EU Listed Companies - Comparative Legal Study, págs. 1 - 18, 18 mai. 2007. Disponível em: <http://www.ecgi.org/osov/documents /study_report_en.pdf $>$. Acessado em 06 mai. 2014.

SUROWIECKI, James. Unequal Shares. The New Yorker, 28 mai. 2012. Disponível em <http:/www.newyorker.com/talk/financial/2012/05/28/1205 28ta_talk_surowiecki>. Acessado em 06 mai. 2014.

TRINDADE, Marcelo Fernandez. Voto no âmbito do Processo Administrativo CVM No RJ2005/7329, em 31 jan. 2006.

VALVERDE, Trajano de Miranda. Sociedades por Ações. Rio de Janeiro: Forense, 1959, vol. 1, págs. $85-91$. 
WALD, Arnoldo. Da Aquisição do Direito de Voto pelas Ações Preferenciais por Falta de Pagamento dos Dividendos Interpretação do Art. 111 , e $\S 1^{\circ}$ da Lei 6.404/76. Revista de Direito Bancário e do mercado de Capitais, 2001, vol. 12, págs. 29 - 40 .

WALD, Arnoldo. Do Direito de Voto dos Titulares de Ações Preferenciais Após o Decurso de Três Exercícios sem Pagamento de Dividendos. Revista dos Tribunais, 1988, vol. 634, págs. 7 - 13 .

WALD, Arnoldo. Em defesa das Ações Preferenciais. Revista de Direito Mercantil, Industrial, Econômico e Financeiro, nº 78, 1990, págs. 19 - 25 
A presente Monografia, apresentada pelo aluno

poderá ser submetida à exposição e defesa perante a Banca Examinadora designada pelo Departamento de Direito da PUC-Rio.

Rio de Janeiro, de de 2014 .

Nome do professor orientador

Assinatura do professor orientador

O autor declara para todos os fins de Direito ser este um trabalho inédito de sua autoria e autoriza o Departamento de Direito da PUC-Rio a divulgá-lo, no todo ou em parte, resguardados os direitos autorais conforme legislação vigente.

Rio de Janeiro, de 2014. 